\title{
The Function of the European Commission - Lessons from the Accession of Bulgaria and Romania
}

by

Martin Vihrenov Manolov, B.A. (hon.)

A thesis submitted to the Faculty of Graduate studies and Research in partial fulfillment of the requirements for the degree of

Master of Arts

Institute of European, Russian, and Eurasian Studies

\author{
Carleton University \\ Ottawa, ON
}

September 2010

(C) 2010, Martin V. Manolov 


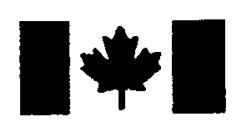

\author{
Library and Archives \\ Canada \\ Published Heritage \\ Branch \\ 395 Wellington Street \\ Ottawa ON K1A ON4 \\ Canada
}

Bibliothèque et

Archives Canada

Direction du

Patrimoine de l'édition

395 , rue Wellington

Ottawa ON K1A ON4

Canada
Your file Votre référence
ISBN: $978-0-494-71687-8$
Our file Notre référence
ISBN: $978-0-494-71687-8$
NOTICE:

The author has granted a nonexclusive license allowing Library and Archives Canada to reproduce, publish, archive, preserve, conserve, communicate to the public by telecommunication or on the Internet, loan, distribute and sell theses worldwide, for commercial or noncommercial purposes, in microform, paper, electronic and/or any other formats.

The author retains copyright ownership and moral rights in this thesis. Neither the thesis nor substantial extracts from it may be printed or otherwise reproduced without the author's permission.
AVIS:

L'auteur a accordé une licence non exclusive permettant à la Bibliothèque et Archives Canada de reproduire, publier, archiver, sauvegarder, conserver, transmettre au public par télécommunication ou par l'Internet, prêter, distribuer et vendre des thèses partout dans le monde, à des fins commerciales ou autres, sur support microforme, papier, électronique et/ou autres formats.

L'auteur conserve la propriété du droit d'auteur et des droits moraux qui protège cette thèse. $\mathrm{Ni}$ la thèse ni des extraits substantiels de celle-ci ne doivent être imprimés ou autrement reproduits sans son autorisation.
In compliance with the Canadian Privacy Act some supporting forms may have been removed from this thesis.

While these forms may be included in the document page count, their removal does not represent any loss of content from the thesis.
Conformément à la loi canadienne sur la protection de la vie privée, quelques formulaires secondaires ont été enlevés de cette thèse.

Bien que ces formulaires aient inclus dans la pagination, il n'y aura aucun contenu manquant.

\section{Canadä}




\begin{abstract}
This thesis seeks to determine the role of the European Commission within the accession of Bulgaria and Romania to the European Union. The evaluation of this role is limited to the inter-institutional interactions between the Commission and the member states. In order to achieve this goal I present a set of three variables, which are developed from the theoretical framework of principal-agent theory, and form the basis for empirical analysis. The ensuing empirical analysis provides a detailed description of the enlargement process on the foundation of which I apply the three variables. The analysis reveals that the role of the Commission was for the most part that of a bureaucratic entrepreneur for the member states, with the ability to influence the strategies for the attainment of their objectives.
\end{abstract}


To my mom, dad and Aysegul 


\section{Acknowledgements}

I would like to thank my supervisor Dr. Achim Hurrelmann for all the valuable suggestions and guidance, support and patience, and help and encouragement throughout this entire process. In this same vain I would like to extend my gratitude to the Department of European, Russian and Eurasian studies, to Ginette Lafleur - our wonderfully kind and knowledgeable administrator, to our department chair Dr. Jeff Sahadeo, and everyone who is a part of this wonderful team of scholars and educators.

I also wish to thank the Center for European Studies, Dr. Robert Gould and the team of people that made it possible for me to travel to Brussels and gain valuable insight into the inner workings of the European Commission, without which this thesis project would not have been possible.

My warmest acknowledgments go to my parents. Without their relentless help, support and love it would not have been possible for me to complete this work. Thank you for everything mom, dad and stara-maika, with undying love: your son!

Lastly, I wish to thank my partner, Aysegul Ergul, for all her love, patience and support that she has provided throughout this lengthy and difficult process. Without you my love I would have been lost. With all my heart, thank you! 


\section{Table of Contents}

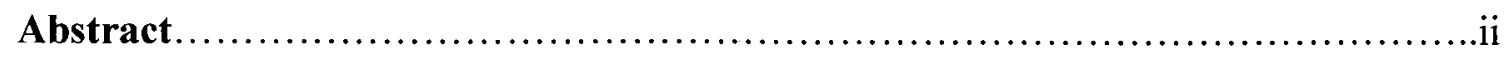

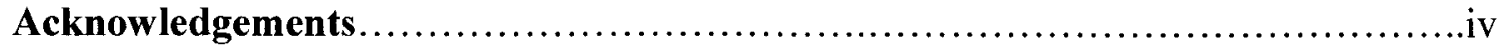

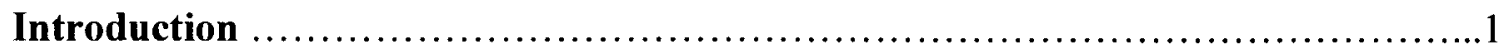

Chapter I: A Framework for Analysis . ......................................11

Section I-Literature Review: .....................................11

Section II-The Principal-Agent Framework: ...........................20

Section III - The Modes of Delegation: ...................................26

Section IV-The Theoretical Framework for Analysis: ........................31

Chapter II: The Pre-Negotiation Stage ........................................ 37

Section I - The Europe Agreements: .................................. 38

Section II-The Pre-Accession Strategy: ................................44

Section III-The White Paper: .......................................50

Section IV-Agenda 2000:......................................... 55

Section V-From Luxemburg to Helsinki: ................................66

Section VI-Overall Evaluation: .......................................... 72

Chapter III: The Negotiation Stage ........................................ 74

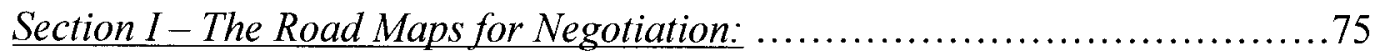

Section II - The Draft Common Positions: ...............................83

Section III-The Working Group: .....................................88

Section IV - The Substantive Negotiations: ..............................100

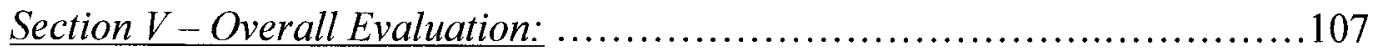

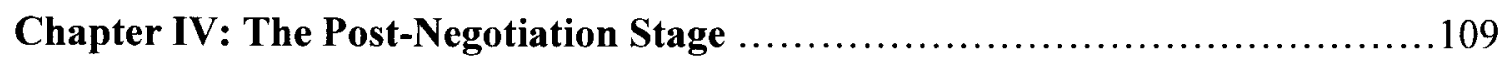

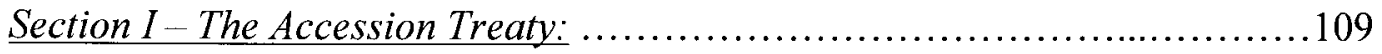

Section II - The Cooperation and Verification Mechanism: .................... 114

Section III-Overall Evaluation: .................................... 120

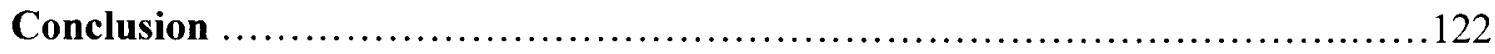

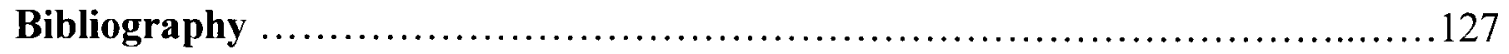




\section{Introduction}

The European Commission is an important actor in the political theatre that is the European Union. This is evidenced by the innumerable scholarly publications discussing its various roles. As such, academic debate and analysis has raged on ever since the Treaty of Rome established the existence of the Commission. Throughout this debate the supranational institution has been identified as an initiator, administrator, guardian of the legal framework, external representative, and a mediator. ${ }^{1}$ These functions carry with them two basic implications. On the one hand, as an initiator, external representative and guardian of the legal framework, the Commission is awarded the primary role of steering the direction of the policies of the Union, thus identifying the supranational institution as supremely influential. Conversely, as an administrator, and a mediator, the supranational institution takes on a supporting role behind the direction provided by the member states, thereby implying that the institution is significantly less influential to the policy processes of the Union. These two implications form the very basis of the lengthy scholarly debate. The duration of which illustrates the confusion that characterizes the understanding of this role; confusion, which is fundamentally grounded in the founding Treaty itself. ${ }^{2}$ The Treaty locates the role of the Commission as the institution that shall "ensure the proper functioning and development of the common market. ${ }^{3}$

Conversely, in Article 9c of the same Treaty, the member states have established that the Council may "confer on the Commission, in the acts which the Council adopts,

\footnotetext{
1 Michelle Cini, The European Commission - Leadership, organisation and culture in administration (Manchester and New York: Manchester University Press, 1996).

${ }^{2}$ Ibid.

3 Council, CONSOLIDATED VERSION OF THE TREATY ON THE FUNCTIONING OF THE EUROPEAN UNION, Official Journal of the European Union, Council of Ministers (Brussels: Council of Ministers, 2008), Article 9d, formerly Article 211 TEU.
} 
powers for the implementation of the rules which the Council lays down. The Council may impose certain requirements in respect of the exercise of these powers. The Council may also reserve the right, in specific cases, to exercise directly implementing powers itself" ${ }^{4}$ Moreover, in Article 241 the member states have stated that the Council "may request the Commission to undertake any studies the Council considers desirable for the attainment of the common objectives, and to submit to it any appropriate proposals". 5 This suggests that while the Commission is responsible for the functioning of the internal market, issues related to external relations are in the hands of the member states, which may subsequently choose to delegate duties to the Commission. This in turn carries the implication that the role of the Commission would be significantly weaker in policies related to external relations than in policies related to the internal market.

Consequently, academics have awarded the most attention to the role of the institution within the internal market related policies. More recently however, scholars have turned their concentration to the areas under the Common Foreign and Security Policy (CFSP). Conversely, relatively little attention has been paid to the role of the Commission in the policy field related to the Enlargement of the European Union. ${ }^{6}$ This particular policy field presents a rather curious case due to its peculiar location within the EU policy structure. The enlargement policy as such is not a distinct component under the (former) First Pillar, although most of the Chapters of the acquis communautaire cover the internal market, and as such are distinctly a part of the competencies of the

\footnotetext{
${ }^{4}$ Ibid, formerly Article 202 TEU, 138.

${ }^{5}$ Ibid, formerly Article 208 TEU, 138.

${ }^{6}$ This is not to say that no studies in this field have been carried out, rather the point here is that they have been relatively few in comparison to the studies of the role of the Commission within other policy fields. This discussion is more thoroughly developed in the literature review section of Chapter I and therefore, it will not be discussed any further here.
} 
supranational institution. Similarly, the enlargement policy is neither a distinct component under the (former) Second Pillar, although all the major decisions associated with this policy are taken by the member states and under unanimity. This is additionally complicated by the fact that the enlargement policy concludes with the signing of Treaties between the member states and the candidate states, which in effect awards this policy a Treaty change component. All of this makes it more difficult to ascertain what role is played by the European Commission in this policy field.

Nevertheless, the enlargement policy, shares its importance with the CFSP due to the fact that it is de facto an area of external relations, and as such, it is not a direct responsibility of the Commission. Sedelmeier even goes as far as to suggest that the "EU's policy towards the CEECs could be interpreted as a (test) of collective foreign policy making". 7 As a result, the important distinction between the internal market and external relations fields is that within the internal market policies the Commission has the right of initiative, which means that the Commission is responsible for setting the agenda for the policies of the Union. ${ }^{8}$ Conversely, in the areas of external relations the institution is not in possession of the same agenda setting powers. ${ }^{9}$

This difference, particularly with regards to the enlargement field, is made more explicit within Article 49 of the TEU, which states that any European state may become a member of the Union by addressing "its application to the Council, which shall act unanimously after consulting the Commission and after receiving the assent of the

\footnotetext{
${ }^{7}$ Ulrich Sedelmeier, "Eastern Enlargement: Risk, Rationality, and Role-Compliance," Maria Green Cowles and Michael Smith, The State of the European Union - Risks, Reform, Resistance, and Revival, Vol. 5 (Oxford: Oxford University Press, 2000) 164-186, 164

${ }^{8}$ Mark A. Pollack, The Engines of European Integration - Delegation, Agency, and Agenda Setting in the EU (Oxford University Press, 2003).

${ }^{9}$ Simon Hix, The Political System of the European Union (New York: St. Martin's Press, 1999).
} 
European Parliament, which shall act by an absolute majority of its component members.

The conditions of admission and the adjustments to the Treaties on which the Union is founded, which such admission entails, shall be the subject of an agreement between the Member States and the applicant State [emphasis added]" ${ }^{10}$ This is supplanted by the Commission in clarifying that "the Council decides whether to accept the application. Once the Council unanimously agrees on a negotiating mandate, negotiations may be formally opened between the candidate and all the Member States [emphasis added]".11

Therefore, it could be expected that the Commission is not very influential in the field of EU enlargement. However, this is an assumption that requires empirical evaluation. As such, this is the main goal of this thesis. This is based on the understanding that such empirical evaluation will provide valuable information regarding the internal power dynamics within the institutional structure of the European Union. As a result, the main goal of thesis is to contribute to the understanding of this internal power dynamic. This will in turn contribute to a better understanding of the Commission itself and its relationship to the member states. Enlargement however, due to its encompassing nature, offers a rich and fruitful soil where a plethora analytical seeds may quickly grow to become dense forests of knowledge, where scholars from almost any strand of the social sciences can find a parcel for cultivation. As such, this paper is located on but a square inch of this field. The following few paragraphs will locate this parcel more precisely.

\footnotetext{
10 Council, TREATY ON THE FUNCTIONING OF THE EUROPEAN UNION, (Brussels: Council of Ministers, 2008), Formerly Article 49 TEU, 35.

11 Commission, Conditions for Enlargement, 15 June 2010, European Commission, 19 August 2010 http:/ec,europa eu/enlargement the-policy conditions-for-enlargement/index en.htm, paragraph 3.
} 
Friis and Murphy have argued that the enlargement process is shaped by the resolution of the "effects of boundary change". 12 This is based on their understanding that enlargement as such, alters the governance boundaries - which the authors define as: institutional, legal, transactional, geographical and political cultural - of the European Union. ${ }^{13}$ Consequently, these "effects of boundary change" are mitigated through the inter-institutional interaction between the Commission and the member states. ${ }^{14}$ Here the Commission serves the role as the manager of the process. ${ }^{15}$ In this capacity the function of the institution varies depending on the quantity and quality of the effects of boundary change. These in turn, depend on the political and economic circumstances of the candidate states. During the enlargement rounds previous to the accession of the Central and Eastern European Countries, this boundary change has been relatively small and consequently, the role of the supranational institution has been smaller. ${ }^{16}$ Conversely, the 2004 enlargement has presented some major difficulties resulting from their transition to stable democracies. ${ }^{17}$ As such, this provided the opportunity for a more encompassing role of the Commission. In this respect the interaction between the supranational institution and the member states was also larger. Therefore, the question that can be asked as a result is: What was the nature of this interaction? This remains unanswered by

12 Lykke Friis and Anna Murphy, "Enlargement: A Complex Juggling Act," Maria Green Cowles and Michael Smith, The State of the European Union - Risks, Reform, Resistance, and Revival (Oxford University Press, 2000) 186-207, 191.

${ }^{13}$ Ibid.

${ }^{14}$ Ibid.

${ }^{15}$ Neill Nugent, The European Commission (New York: Palgrave, 2001).

${ }^{16}$ Ibid.

${ }^{17}$ Ibid. 
Friis and Murphy and is in fact largely a neglected topic within the enlargement literature. ${ }^{18}$ As a result this question forms the basis for the discussion within this paper.

While the accession of the ten Central and Eastern European Countries in 2004 has been the subject of repeated and thorough analysis, the accession of Bulgaria and Romania has received far less attention. This is mostly due to the fact that both scholars and practitioners consider the accession of these two countries as an extension of the 2004 accession process. This is despite the fact that the slow progress of reforms in the two countries left them out from the first round of accession. ${ }^{19}$ Nevertheless, there were some significant differences that separate the two waves of accession. The most notable such difference is the application of the Cooperation and Verification Mechanism to both Bulgaria and Romania; such tools were not employed in any previous round of accession. In addition, and due to Bulgaria and Romania's lagging reforms, new frameworks had to be established to fit their particular circumstances. This illustrates that while the accession of Bulgaria and Romania was indeed a part of the fifth enlargement round, it was also sufficiently different to warrant an evaluation on its own merits. Therefore, it is this process that will be evaluated within this paper.

Recalling the qualification presented above, the research question is therefore, best formulated thus: What was the role of the European Commission within the accession of Bulgaria and Romania to the European Union? This question carries in its fabric some limitations, which require further discussion. First and foremost, this

\footnotetext{
${ }^{18}$ Indeed, this is not to say that the scholarship within the greater field of European Integration has neglected this topic, one simply has to browse for the term Multi-Level Governance in order to find evidence of the popularity of the analysis of inter-institutional interactions. Nevertheless, these analyses are in general concerned with the processes within the European Union, that is to say within the policies that are concerned with the deepening of the Union, rather than its widening.

${ }^{19}$ The countries that joined the Union in 2004 were: Malta, Cyprus, Estonia, Latvia, Lithuania, Poland, Czech Republic, Slovakia, Slovenia and Hungary.
} 
question only seeks to examine the function of the supranational institution vis-à-vis the already existing member states. This is an important qualifying characteristic because one could also seek to ascertain the role of the institution vis-à-vis the candidate states, however, this in itself is a topic of a paper of similar proportions. More importantly, however, the interaction between the Commission and the candidate states is a fundamentally different process, one that is characterized by a power relationship clearly in the favor of the supranational institution. ${ }^{20}$ As such, this is not discussed in this paper. Nevertheless, it should be noted that on occasion the empirical analysis presented in this thesis comes into contact with this topic. This however, is very limited and is always with reference to the interaction between the Commission and the member states.

The second limitation inherent in this research question is a temporal one. Therefore, the time-period that will be examined only covers the process of accession. This means that any policy processes that has occurred prior to the preparation of the Europe Agreements for the two countries in 1990; and similarly any policy process that has occurred following their accession on January $1^{\text {st }}$ of 2007 , will not find itself as a component of this paper. The last limitation is not as explicit within the research question itself as the former two, nevertheless it is of paramount importance. This refers to the various policy processes that will be examined. Each major development of the accession process is followed by a sub-group of policy processes; as such this paper will only discuss these major developments. This is mainly because these being the major milestones of the enlargement process can provide a sufficiently cohesive picture while simultaneously retaining this paper within the framework for a project of this variety.

\footnotetext{
${ }^{20}$ In fact, one interviewee has recalled that during his time spent as a member states representative in Romania the head of delegation of the Commission was amicably called the viceroy of Romania, thus suggesting the immense influence the Commission had over the candidate states.
} 
Consequently, in order to adhere to these limitations and simultaneously to present a thorough analysis of the question, in the format of this thesis I will combine a historical and political science approach in its ranks and thereby I will present an interdisciplinary analysis of the inter-institutional interactions within this policy field.

In order to achieve the goals set out above, the logical progression of the argument requires a theoretical framework for analysis and an empirical basis for evaluation; where on the basis of the theoretical framework I will examine the interinstitution interaction between the Commission and the member states throughout the accession process of Bulgaria and Romania. Consequently, in the theoretical component I will employ a variety of scholarly publications - that is articles and books. The following empirical component is less dependent on secondary sources, though some are indeed included. Rather the sources used here will be government documents and interviews conducted by the author. The government documents include presidency conclusions from the European Council, reports and presidency conclusions form the various formations of the Council of Ministers - most frequently this means the General Affairs and External Relations Council (GAERC) - and finally reports from the European Commission. The personal interviews include conversations with officials from the European Commission as well as members of the Council working group on enlargement. The division of this thesis between theory and empirics however, does not reflect the number of chapters that will be presented. In fact the theoretical component is the basis of Chapter I singularly. Conversely, the empirical component forms the basis for Chapters II, III and IV. 
The first chapter as such, begins with a thorough review of the academic literature on the topic of the Eastern enlargement of the European Union. This includes a brief discussion of the areas not covered by this project such as Europeanization or the grandbargains theories. Within this literature review I will more thoroughly illustrate that there largely exists an unabridged disagreement between scholars regarding the institutional role of the Commission within this process. As such, I will propose that a thorough empirical analysis may provide a type of bridging device. Consequently, in the following sections of the theoretical Chapter I will set out the framework on the basis of which such empirical analysis may be conducted. This is mainly rooted in principal-agent theory as well as a discussion of the various modes of delegation of duties. At its conclusion this Chapter will identify three variables that could evaluate the role of the Commission throughout the evidence discussed above - that is the government documents and personal interviews.

The second component of this thesis is thoroughly empirical in nature. It is within this empirical evaluation that the historical approach finds its focus. As such, this component is characterized by the thorough description of the various milestones of the accession process. Consequently, this component of the paper is divided into three separate chapters. This is based on the understanding that the enlargement process may be divided into separate instances. Some authors have proposed this division to be based on the various elements of the process, such as, application, negotiation, ratification and so on. ${ }^{21}$ Others have suggested that a better distinction is based on the temporal

\footnotetext{
${ }^{21}$ See Desmond Dinan, "National Interests and Supranational Solutions," Europe Recast - A History of European Union (Lynne Rienner, 2004) 321-323.
} 
progression of the negotiations. ${ }^{22}$ However, I have adopted a third approach, which separates the enlargement process into three basic stages, pre-negotiation, negotiation, and post-negotiation. ${ }^{23}$ This division is best suited for the purposes of this project because it allows each section to be divided into the various subsections that make up the milestones of the inter-institutional interaction. Therefore, this division also reflects the three chapters that comprise the empirical component of this work.

The second chapter, which reflects the pre-negotiation stage, is divided into six sections, each of which is a reflection of an important phase along the process of accession. These include the Europe Agreements, the pre-accession strategy, the white paper, Agenda 2000, and the decision to commence negotiations with Bulgaria and Romania at the Helsinki European Council meeting in 1999. Conversely, the third chapter, which reflects the negotiation stage, is divided into five sections. These include the discussion of the road maps for the negotiations, the draft common positions for negotiation, the creation of the EU common position by the Council working group on enlargement, and the substantive negotiations between the candidate states and the Union. Lastly, the fourth chapter is, in comparison, significantly shorter than the previous two. This is mainly because the post-negotiation stage is relatively brief, as such the discussion is centered on two topics, the preparation of the Accession Treaty and the creation of the Cooperation and Verification Mechanisms, which also reflect the two sections of this chapter. The final section of each chapter is a brief overview of the empirical analysis presented at the conclusion of each section.

\footnotetext{
${ }^{22}$ See Graham Avery, "The Enlargement Negotiations," Fraser Cameron, The Future of Europe Integration and Enlargement (Routledge, 2004) 35-63.

${ }^{23}$ This approach was developed by Nikolova, and has therefore been adapted to fit this project. For the original incarnation see Pavlina Nikolova, "Negotiating for EU Membership? - The Case of Bulgaria and Romania," Croatian Yearbook of European Law and Policy 2.1 (2006): 393-412.
} 


\section{Chapter I: A Framework For Analysis}

Section I-The Literature Review:

The academic literature on the Eastern enlargement of the European Union can be divided into four broad categories: institutional reforms, reasons for enlargement, Europeanization and the study of the process of enlargement itself.

The institutional reforms strand of the literature examines the various changes that the EU itself would be required to implement in order to be able to absorb the accession of the candidate states from Central and Eastern Europe. The underlying question asked by scholars working in this field is: What is the institutional impact of the European Union's expansion Eastward? The basic arguments suggest that the increased membership would pose significant challenges to the decision-making, the management, and the legitimacy of the European Union. ${ }^{1}$

The second strand of literature examines the reasons why the member states agree to accept the candidates from Central and Eastern Europe and why the candidate states wish to join the Union. Consequently, this includes both theoretical and empirical studies. On the one hand, from the Liberal Intergovernmentalist tradition, Moravcsik and Vachudova have argued that the Eastern enlargement of the EU is the result of a rational calculation of the economic and geopolitical interests of both the member states and the candidate states. ${ }^{2}$ On the other hand Social Constructivists have suggested that the

\footnotetext{
1 Dehaene, J.-L., Simon, D., \& von Weizsacker, R. (1999). The Institutional Implication of Enlargement: Report to the European Commission. Brussels: European Commission. Also see: Steunenberg, B. (2002). Widening the European Union - The politics of institutional change and reform. London and New York: Routledge; Neunreither, K., \& Weiner, A. (2000). European Integration After Amsterdam - Institutional Dynamics and Prospects for Democracy. Oxford: Oxford University Press, Pusca, A. (2004). European Union - Challenges and Promises of a New Enlargement. New York: The International Debate Education Association.

2 Moravcsik, A., \& Vachudova, M. A. (2003). National Interests, State Power, and EU Enlargment. East European Politics and Scocieties , 17 (1), 42-57; Moravcsik, A., \& Vachudova, M. A. (2002). Bargaining
} 
enlargement was made possible due to the collective identity of the Union. ${ }^{3}$ Empirically, one is presented with a large multiplicity of economic arguments outlining the costs and benefits of enlargement both for the member states and the candidate states. ${ }^{4}$

The third area for academic enquiry is the process of Europeanization. In this area, scholars have postulated that the expansion of the Union ushers a form of transformation of the candidate states in a way that is much more unprecedented during the Eastern enlargements of 2004 and 2007 than any previous such rounds. ${ }^{5}$ The basic question asked by these scholars is: How does the EU alter the political and administrative landscape of the countries of Central and Eastern Europe?

The discussion of the previous three categories suggests that much of the literature on the process of enlargement does not evaluate the role that the Commission played in this process. In contrast, the fourth major area for research has been the study of the process of enlargement itself. The basic question asked by scholars in this field is: How does the enlargement process unfold? This question is more conducive for an evaluation of the institutional functions and consequently, in many instances, such

Among Unequals: Enlargment and the Future of European Integration. European Union Studies Association, 15 (4); Moravcsik, A., \& Vachudova, M. A. (2005). Preferences, power and equilibrium: the causes and consequences of EU enlargement. In F. Schimmelfennig, \& U. Sedelmeier (Eds.), The Politics of European Union Enlargement (pp. 198-213). Routledge.

${ }^{3}$ Sedelmeier, U. (2000). Eastern Enlargement: Risk, Rationality, and Role-Compliance. In M. G. Cowles, \& M. Smith, The State of the European Union - Risks, Reform, Resistance, and Revival (Vol. 5, pp. 164186). Oxford: Oxford University Press; Schimmelfennig, F. (2005). The Community Trap: Liberal norms, rethorical action and the eastern enlargement of the European Union. In F. Schimmelfennig, \& U. Sedelmeier, The Politics of European Union Enlargement - Theoretical Approaches (pp. 142-172). London and New York: Routledge; O'Brennan, J. (2006). The European Commission and eastern enlargement: Conceptualising eastern enlargement. In The Eastern Enlargement of the European Union (pp. 74-95; 113 172). Routledge,

${ }^{4}$ Piazolo, D. (2001). The Integration Process between Eastern and Western Europe. Springer; Baldwin, R. E. (1995). The Eastern enlargement of the European Union. European Economic Review, 39, 474-481; Baldwin, R., Francois, J. F., \& Portes, R. (2002). The costs and benefits of eastern enlargement: the impact on the EU and central Europe. Economic Policy, 12 (24).

5 Schimmelfennig, F., \& Sedelmeier, U. (2005). The Europeanisation of Central and Eastern Europe. Ithaca and London: Cornell University Press; Grabbe, H. (2006). The EU's Transformative Power Europeanisation Through Conditionality in Central and Eastern Europe. New York: Palgrave. 
analyses have also included the examination of the role of the various supranational institutions, most notably the European Commission. It is within this compartment that this paper is located. As such, it is beneficial to provide a more in-depth analysis of the existing academic contributions.

This analysis will be divided into two categories. First, I will present a discussion of the methodologies and the various aspects of the enlargement process that existing scholarship employs and analyzes. Second, I will briefly engage with the different arguments and analytical conclusions presented by the authors.

Baun has provided one of the most comprehensive accounts of the process of Eastern enlargement to date. ${ }^{6}$ In this work the author has focused on the development of the EU's policy on enlargement. As such, Baun describes in considerable detail the Europe Agreements, pre-accession strategy, the Commission's opinions on the candidate states and the negotiation process itself. The analysis is carried out on the basis of a comparison between previous enlargements and it includes the evaluation of key dynamics and issues. ${ }^{7}$ Baun acknowledges however, that this work is only a snapshot in time and as such is only able to describe the process up to a point. ${ }^{8}$ This is all the more significant considering the fact that the work was published prior to the end of the substantive negotiations between the Union and the candidate states.

Unlike Baun, Mayhew has focused his analysis on two aspects of the enlargement process. First, the author has described the Association Agreements between the EU and

\footnotetext{
${ }^{6}$ Michael J Baun, A Wider Europe: The Process and Politics of European Union Enlargement (Rowman \& Littlefield Publishers Inc., 2000).

${ }^{7}$ Ibid.

${ }^{8}$ Ibid.
} 
the candidate states of Central and Eastern Europe. ${ }^{9}$ In this work Mayhew has investigated the relationship between the candidate states and the member states, the impact of these agreements as well as their inherent challenges. ${ }^{10}$ Second, the author has provided a detailed analysis of the progress of the substantive accession negotiations. ${ }^{11}$ In this text Mayhew has explored the reasons for the variable speed of the negotiations by examining the various policy-areas that were at the core of the negotiations. ${ }^{12}$ Both works, similarly to Baun's publication, are limited by the fact that they were published prior to the conclusion of the accession process, and therefore both provide an incomplete account of this process.

Similarly to Mayhew, Avery has also presented a description of the substantive negotiations between the candidate states and the EU. Avery's work however has a larger temporal focus, stretching between 1998 and $2003 .{ }^{13}$ As a result, this study is in a sense complementary to Mayhew's, in that it also provides a reflection on the main challenges of the entire progress of the negotiations through the analysis of the most significant chapters of the acquis. A comparable and complementary study is also provided by Franco, who discusses the procedural aspects of the enlargement and analyses those visà-vis the existing (at the time) Association Agreements between the member states and

\footnotetext{
${ }^{9}$ Alan Mayhew, Recreating Europe - The European Union's Policy towards Central and Eastern Europe (Cambridge University Press, 1998).

${ }^{10}$ Ibid.

${ }^{11}$ Alan Mayhew, "Enlargement of the European Union: An Analysis of the Negotiations with the Central and Eastern European Candidate Countries," SEI Working Paper No.39, December 2000: 2-71.

${ }^{12}$ Ibid.

13 Graham Avery, "The Enlargement Negotiations," in The Future of Europe - Integration and Enlargement, 35-63 (Routledge, 2004).
} 
the candidate states. ${ }^{14}$ Similarly, Inotai has examined the criteria for enlargement and the challenges associated with these criteria. ${ }^{15}$

In contrast to the previous authors, Nugent offers an analysis of the enlargement process following the conclusion of the accession negotiations with the ten countries acceding in $2004 .^{16}$ Nugent provides a basic overview of the enlargement process and locates this in relation to previous enlargement rounds and the attitudes of the member states towards the candidate states. ${ }^{17}$ Similar to Nugent, Pool has also benefited from writing following the preliminary closure of most of the negotiating chapters between the EU and the 2004 group of acceding candidate states. ${ }^{18}$ This author has provided an overview of the process by explaining the various stages through a descriptive approach which is a component of the larger exercise of his monograph - the analysis of the consequences of the enlargement on the European Union. ${ }^{19}$

The element that is a constant in the scholarship of these authors is that the focus of their work heavily favors the countries acceding in 2004 . While most do mention some details concerning Bulgaria and Romania's accession negotiations, few have this as the main feature of their work. Nikolova, who has discussed only Bulgaria and Romania's experiences on the road to accession, breaks this mould. ${ }^{20}$ The author examined the membership criteria and the various stages of the accession process of the two candidate

14 Marc Franco, "The enlargement: the European Commission's viewpoint.." in The Enlargement of the European Union - Issues and Strategies, 67-76 (London \& New York: Routledge, 1999).

15 Andras Inotai, "The CEECs: From the Association Agreements to Full Membership?," in The Expanding European Union - Past, Present, Future, 157-177 (London: Lynne Rienner Publishers, 1998).

${ }^{16}$ Neill Nugent, "The Unfolding of the 10+2 Enlargement Round," in European Union Enlargement, 34-56 (New York: Palgrave, 204).

${ }^{17}$ Ibid.

${ }^{18}$ Peter A. Poole, The EU's Eastern Enlargement (London: Praeger, 2003).

${ }^{19}$ Ibid.

20 Pavlina Nikolova, "Negotiating for EU Membership? - The Case of Bulgaria and Romania," Croatian Yearbook of European Law and Policy 2, no. 1 (2006): 393-412. 
states while presenting an inter-institutional analysis of the relationship between the candidate states and the Commission. ${ }^{21}$

Most of the authors have examined the accession process through the use of a descriptive approach. It is in the context of this description that the analysis of the institutional role of supranational institutions, such as the Commission, is discussed. While this broader fourth category of scholarship allows for a variety of approaches and seemingly unconnected analysis to be employed and carried out, one can identify two major scholastic camps. On the one hand we have authors who view the supranational institution as the engine of integration, and on the other there are those who assert that it is the member states, which through their own volition, move the enlargement process forward. The arguments discussed below reflect this division within the academic scholarship.

Mayhew has argued that the accession of the CEECs was more complicated than the previous accession rounds. This was the result of the completion of the internal single market and the negotiation of the Maastricht Treaty. The completion of the internal market posed difficulties due to its complex structure and inherent economic globalization. ${ }^{22}$ In turn, the Maastricht Treaty, with its inclusion of the Common Foreign and Security Policy and Justice and Home Affairs extended the acquis communautaire "massively, making preparation for accession more difficult". ${ }^{23}$ This has increased the need for collective problem solving. ${ }^{24}$ Consequently, Friis and Murphy have suggested,

\footnotetext{
${ }^{21}$ Ibid.

${ }^{22}$ Mayhew, SEI Working Paper No.39, (December 2000) pp. 2-71.

${ }^{23}$ Ibid, 5-6.

24 Lykke Friis and Anna Murphy, "Enlargement: A Complex Juggling Act." in The State of the European Union - Risks, Reform, Resistance, and Revival, 186-207 (Oxford University Press, 2000).
} 
that governance as such "is no longer exclusively conducted by the state". 25 This points to the importance of the European Commission as a key component of enlargement process. This view is also shared by most scholars working in the field of enlargement, with the notable exception of Liberal Intergovernmentalists such as Moravcsik and Vachudova, who have maintained that the engines of enlargement were the member states. $^{26}$

In contrast to Liberal Intergovernmentalists, Social Constructivists like Sedelmeier, have argued that the key factor in the EU's Eastern enlargement policy was the EU's "collective identity vis-à-vis the CEECs". ${ }^{27}$ This collective identity was and still is most strongly manifested within the ranks of the "policy-makers acting on behalf of the $E U,{ }^{28}$ This argument presented by Sedelmeier suggests that the role of the Commission is de facto the engine of the enlargement process. Similarly, Grabbe has argued that one of the main reasons for the increased importance of the Commission is the "unwillingness" of the member states to "take political responsibility for enlargement". ${ }^{29}$ This same reluctance has prompted the member states to demand stricter conditionality, thereby attempting to delay the process. ${ }^{30}$ As a result, the increased mandate of the Commission was a "functional response to the increase[ed] complexity of the conditionality" where the Commission was the "single coordinating instrument" between the member states and the candidate states. ${ }^{31}$

\footnotetext{
${ }^{25}$ Ibid, 188.

${ }^{26}$ Moravesik \& Vachudova, National Interests, State Power, and EU Enlargment. (2000), 17 (1), 42-57.

27 Ulrich Sedelmeier, Constructing the Path to Eastern Enlargement - The Uneven Policy Impact of EU Identity (Manchester University Press, 2006), 9.

${ }^{28}$ Ibid, 9 .

${ }^{29}$ Grabbe, The EU's Transformative Power (Palgrave, 2006), 28.

${ }^{30}$ Ibid.

${ }^{31}$ Ibid, 27
} 
Avery's account of the institutional role of the Commission, while not fully supporting the proposition that the member states are the sole engines of the enlargement process, differs somewhat from that of Sedelmeier and Grabbe in that this author has argued that the formal role of the Commission was secondary as it was only "asked to explain or defend the EU's point of view". ${ }^{32}$ Nevertheless, the informal role of the institution was pivotal. This was the result of three main factors. ${ }^{33}$ First, the Commission has the right of initiative. Second, many of the issues under discussion were highly technical. Third, the applicants perceived the Commission as an "honest broker" interested in finding solutions and moving the process forward. ${ }^{34}$

Another aspect of the examination of the institutional role of the Commission is focused on the analysis of the various stages of the enlargement process. Grabbe has argued that the Opinions of the Commission in effect "established the Commission's view of the requirements for becoming an EU member state". 35 In addition, the Commission, in its development of the pre-accession strategy, elaborated on the Copenhagen criteria of 1993 by defining the requirements for accession in detail. ${ }^{36}$ Conversely, Baum has argued that while the creation of the pre-accession strategy was "spearheaded" by the Commission, it was the German government that "greatly promoted" this process. $^{37}$

Similarly contentious are the yearly progress reports prepared by the Commission. Nikolova has suggests that these annual progress reports in effect awarded the institution

\footnotetext{
32 Avery, "The Enlargement Negotiations", (Routledge, 2004), 39.

33 Ibid.

34 Ibid, 39.

${ }^{35}$ Grabbe, The EU's Transformative Power (Palgrave, 2006), 14.

${ }^{36}$ Ibid

${ }^{37}$ Baun, A Wider Europe (Rowman \& Littlefield Publishers Inc., 2000), 56.
} 
a gatekeeper status mandating whether a candidate state was able to proceed to the next step of the process. ${ }^{38}$ While these opinions were not legally binding, they proved to be influential in the instances where the member states were "hesitant or diverged in views how to proceed". ${ }^{39}$ Consequently, the "progress towards accession depended on the annual evaluations by the Commission". " Conversely, Avery has identified a relatively lower importance of these progress reports, which the author describes as tools allowing the "applicant countries to accelerate their reforms in the decade that followed the promise in Copenhagen". 41 This contradicts Nikolova's assertion, and suggests that the progress reports were simply a tool for the candidate states rather than of any importance to the member states.

This brief review of the literature has demonstrated the divergence of academic assertions regarding the institutional role of the Commission in the process of the Eastern enlargement of the European Union. More importantly, I have illustrated that, while there is a general divide that separates most authors in contrasting polarities, the divergence of views also precipitates within the sphere of each separate polarity. As a result academics disagree not only on whether the Commission is the engine of the enlargement process, but also on the extent to which the institution is influential.

Despite these distinct divisions within the literature, what all these studies have in common is that none have provided a detailed account of the role of the Commission on the basis of empirical evaluation. It is this gap in the literature that this paper aims to fill. Consequently, this paper will determine a) whether the Commission is influential within

\footnotetext{
${ }^{38}$ Nikolova, "Negotiating for EU Membership?", (2006): 393-412.

${ }^{39}$ Ibid, 401.

${ }^{40}$ lbid, 393.

${ }^{41}$ Avery, "The Enlargement Negotiations", (Routledge, 2004), 38.
} 
the process of enlargement and b) if it is, then to what degree. Therefore, the following three sections of this chapter will establish the theoretical framework on the basis of which such empirical evaluation can be conducted.

\section{Section II-The Principal-Agent Framework:}

In order to be able to empirically analyze the role of the Commission within the enlargement process one requires a theoretical framework that allows one to carry out analysis in such a policy environment. The principal-agent framework provides the right tools for such an evaluation. This theoretical basis enables the researcher to conceptualize the relationship between the member states and the Commission, and through this conceptualization, to develop the variables that would serve as the basis for analysis.

Pollack has defined the principal-agent relationship as a hierarchical model where an "actor or a set of actors known as principals, may choose to delegate certain functions to another actor or actors, known as agents". ${ }^{42}$ Within this model, the member states are a collective principal and the Commission is an executive agent. ${ }^{43}$ In this type of hierarchical relationship the leadership potential of the Commission is limited but not entirely lacking. ${ }^{44}$ Consequently, according to Pollack, there are four primary factors, which explain the autonomy and influence of supranational agents, in this case the European Commission ${ }^{45}$.

a) The distribution of preferences among principals and agents.

\footnotetext{
${ }^{42}$ Pollack, M. A. (1998). The Engines of Integration? Supranational Autonomy and Influence in the European Union. In W. Sandholtz, \& A. Stone Sweet, European Integration and Supranational Governance (pp. 217-250). Oxford University Press, 220.

43 Pollack, M. A. (2000). The Commission as an Agent. In N. Nugent (Ed.), At the Heart of the Union Studies of the European Commission (Second Edition ed., pp. 111-131). Macmillan.

${ }^{44}$ Pollack, The Engines of Integration? (Oxford University Press 1998) pp. 217-250.

${ }^{45}$ The numeric order of these four factors has been re-arranged from the original presented by Pollack in order to better suite the argumentation presented in this paper.
} 
b) The existence and utilization of transnational constituencies of sub-national organizations. $^{46}$

c) The distribution of information among principals and agents.

d) Institutional decision rules governing the delegation of powers. ${ }^{47}$

For the purposes of this paper the first factor - the distribution of preferences between the member states and the Commission - refers to the interaction between the preferences of the member states and the Commission for each individual policy area. Pollack has identified that the literature examining the function of the Commission awards particular attention to the institution's "informal or substantive agenda setting" power. ${ }^{48}$ Meaning that on the basis of the member states' preferences, the Commission is able to define what it determines to be the optimal strategies for the attainment of policy objectives. This reflects the instances where the member states would benefit from common action, however the costs of identifying and negotiating such action inhibit its achievement. $^{49}$ These, so called transaction costs, are either: commitment related, information related, or negotiation related. ${ }^{50}$

In the instances where these costs are commitment related, the principals are unable to "bind themselves or their successor[s] to maintain those policies in the future" and therefore require the agent to ensure compliance. ${ }^{51}$ On such occasions the agent would monitor the compliance of the principals with their preferences on the basis of the agreed upon strategies for implementation. In this capacity the agent would also remind the principals of their commitments if, and when, the principals stray from the latter. In

\footnotetext{
${ }^{46}$ These in the case of the Commission are interest groups and multinational corporations.

${ }^{47}$ Pollack, The Engines of Integration? (Oxford University Press 1998), 221.

${ }^{48}$ Pollack, The Commission as an Agent. (Macmillan 2000), 123.

${ }^{49}$ Ibid.

${ }^{50}$ Pollack, M. A. (2003). The Engines of European Integration - Delegation, Agency, and Agenda Setting in the EU. Oxford University Press.

${ }^{51}$ Ibid, 21.
} 
the instances where the transaction costs are information related, the principals are faced with a "complex policy environment" - where there is a large multiplicity of policy areas that need to be reconciled to the general trajectory of a given proposal - and therefore require expert assistance in generating adequate policy alternatives. ${ }^{52}$ Consequently, the agent - due to its policy-relevant expertise - would propose implementation strategies on the basis of the broad preferences defined by the member states. When the issue is related to the negotiation of policy decisions between multiple principals the agent would then function as a policy leader by bridging member states preferences, which is achieved by collecting requisite information and proposing innovative common strategies for the attainment of these goals. Consequently, when the transaction costs are low the Commission has little independent power, conversely when they are high the supranational institution has more independent power.

A main component of the innovative "problem solving" - that is the bridging of preferences - by the Commission is its ability to gather vast amounts of information regarding the particular policy area in question, which is also the second factor - the utilization of transnational constituencies - discussed by Pollack. The ability of the Commission to mobilize its transnational constituency enables the institution to put pressure on the member states' governments or even bypass them altogether. ${ }^{53}$ However, while this may be possible with respect to other policy areas, it is less likely to be as effective with respect to enlargement due to the requirement for unanimous decisionmaking within the Council of Ministers. Nevertheless, being able to mobilize a large transnational constituency allows the Commission access to vast resources of

\footnotetext{
${ }^{52}$ Ibid, 20.

${ }^{53}$ Pollack, The Engines of Integration? (Oxford University Press 1998).
} 
information. As such, the institution becomes more aware of the various nuances that are in play, both within the member states, and the candidate states.

The third factor - the distribution of information - refers to the difference between the ability of the member states and of the Commission to generate knowledge regarding the different policy decisions. This carries with it the implication that in certain circumstances the Commission may be in possession of more pertinent area-specific knowledge, which the member states have not generated. This also informs the difference between this factor and the information related transaction costs. This difference is characterized by the fact that the information related transaction costs refer to the information that needs to be gathered prior to the policy-making process, whereas this factor refers to the information that the agent may or may not already be in possession of. Consequently, the Commission can be described as, what Hooghe calls, an "epistemic community" - a body of experts with distinct knowledge and relevant expertise. ${ }^{54}$ This variable distribution of information, which is incorporated into the principal-agent relationship under the heading of "informational asymmetry", is also a condition under which the agent may function autonomously. This is based on the understanding that the principal would award some autonomy to the agent because the agent, due to the informational asymmetry, is better equipped to develop and implement the given policy objectives.

The principal-agent framework however, characterizes this autonomy as challenging for the principals, which is also the basis for the fourth factor - the decision rules governing the delegation of power - discussed by Pollack. There are two such

\footnotetext{
${ }^{54}$ Hooghe, L. (2001). Principal or Agent. In L. Hooghe, The Euroepan Commission and the Integration of Europe - Images of Governance (pp. 142-168). Cambridge University Press.
} 
difficulties that the principals have to overcome. ${ }^{55}$ First, the agent may be subject to perverse incentives to behave in ways contrary to the aims of the principals, which is known as "slippage".${ }^{56}$ Second, the agent may use the powers delegated to it in order to pursue its own interests at the expense of those of the principals, a process called "shirking". ${ }^{57}$ This is due to the existence of a difference in ability between the principals and the agents to generate information. The agent thus possesses better quality of information regarding its area of expertise, budgetary needs, and activities. ${ }^{58}$ As a result, the agent may be able to pursue its own agenda, which is assumed to be contrary to that of the principal. ${ }^{59}$ As such, shirking is a process of less severe consequences for the member states, and due to this difference Pollack has argued that slippage is much less likely to occur.

More importantly, as a response to the shirking by the agent, the principals may adopt various oversight procedures. ${ }^{60}$ These allow the principals to monitor the behavior of the agent and influence it by the application of positive and negative sanctions, thus referring to two systemic procedures that govern the function of the supranational institution as well as the decision-making in the enlargement process. ${ }^{61}$ This implies that the Commission may have more autonomy in areas where it has distinct competencies, such as the (former) First Pillar issues. Conversely, the institution would have significantly less discretion in the areas under the (former) Second and Third Pillars.

\footnotetext{
${ }^{55}$ Pollack, The Engines of Integration? (Oxford University Press 1998).

${ }^{56}$ Ibid, 220.

${ }^{57}$ Ibid, 220.

58 Ibid.

${ }^{59}$ Ibid.

${ }^{60}$ Other oversight mechanisms include the European Parliament and the Court of Auditors. Those however are not available to the member states to employ and as such are not included in this analysis.

${ }^{61}$ Pollack, The Engines of Integration? (Oxford University Press 1998)
} 
Pollack has suggested that the member states heavily employ the police-patrol style of agency oversight. ${ }^{62}$ This is manifested through the complex system of oversight committees called comitology. This "allow[s] member governments to monitor Commission activity rather closely, providing them with an accurate picture of the Commission's behavior". ${ }^{63}$ There is also an additional function inherent in the rubric of comitology. While the committees do function as an oversight mechanism they also provide the member states' governments with policy-relevant information, which has been gathered by the Commission. This expands the information provided by the agent to the principal and shrinks the informational asymmetry. These oversight mechanisms however, do not fully eliminate this informational asymmetry. In fact this is not their intended design, rather it is simply a side effect of their existence. As Pollack has suggested, oversight mechanisms are designed to ensure that extreme errors do not occur. $^{64}$

In addition, while comitology is an effective mechanism for monitoring the daily actions of the agent, within the area of enlargement the member states are also capable of vetoing any policy proposal presented by the Commission. This is due to the fact that the decision-making within the enlargement process is based on unanimity rather than Qualified Majority Voting (QMV). As a result, the agent is prompted to ensure that its proposals are best suited to the preferences of the member states. Consequently, when these two types of oversight mechanisms are combined, the member states can ensure that shirking by the agent is minimized.

\footnotetext{
${ }^{62}$ Pollack, The Commission as an Agent (Macmillan 2000).

${ }^{63} \mathrm{Ibid}, 115$.

${ }^{64}$ Ibid.
} 
As a result, the principal-agent model presented by Pollack represents an inherently polarized understanding of the function of the agent. In the one instance the agent is a body that simply follows the directions of the principals, almost entirely lacking in institutional autonomy. Conversely, the alternative is that the agent is awarded some autonomy by the principal, however this autonomy then prompts the agent to act in ways that are contrary to the interests of the principals. Therefore the principals enforce strict supervision over the actions of the agent, which de facto again limits the institutional autonomy of the agent. Consequently, this means that any autonomous action by the agent will necessarily have negative outcomes for the principals.

Section III-The Modes of Delegation:

Similarly to Pollack, Majone has argued that political principals choose to delegate some of their powers to institutional agents. ${ }^{65}$ In this respect however, Majone's main contribution is the identification of two modes for the delegation of authority - the agency mode and the fiduciary mode. ${ }^{66}$ For the purposes of this paper and unlike Majone's original supposition, "delegation" refers to new responsibilities being transferred to the Commission - such as being requested to provide opinions on the candidate states' preparedness to assume the obligations of membership - rather than the old responsibilities, which are already codified within the Treaties.

The two modes of delegation however, are intimately connected to the preferences of the principals, therefore it is important, at this point, to clarify the meaning

\footnotetext{
${ }^{65}$ Majone, G. (2005). Delegation of Power and the Feduciary Principle. In Dilemmas of European Integration: The ambiguities and pitfalls of integration by stealth (pp. 64-82). Oxford University Press. ${ }^{66}$ Ibid.
} 
of the term "preferences". The concept of state preferences, ${ }^{67}$ while intuitively plausible, has proven quite difficult to operationalize, mainly due to the fact that there is "potentially an endless means-ends chain in which any given end can be seen as a means to some other ends depending on what question is being asked" ${ }^{68}$ This challenge arises from the fact that the existing definitions of state preferences lack a distinction between the underlying policy goals of the member states and the various strategies that can be employed in attaining those goals. According to Geddes, rational choice theory offers this distinction. Through this understanding, the underlying policy objectives are "first order preferences" and the strategies for the attainment of these goals are "second order preferences ${ }^{\prime 69}$ As the following paragraphs will illustrate, this distinction is inherent in the two modes of delegation identified by Majone.

\footnotetext{
${ }^{67}$ There are four major theoretical approaches that analyze the establishment of the preferences of the various member states. From a Liberal Intergovernmentalist perspective Moravcsik has argued that national preferences emerge from a process of domestic political conflict where multiplicities of domestic interests play a role. Thus, national preferences are "a reflection of the economic incentives generated by the patterns of economic interdependence", where ideological concerns are of little importance. In contrast Kaiser and Staire describe state preference formation from the theoretical basis of functionalist Transnationalism. According to these authors, state preferences are formed through the contribution of, and interaction between, transnational actors who "contribute to actual policy-making and up to a point, policy implementation". As a result, "state actors often rely on them for the [development of preferences] "vision thing'". A third perspective is provided by the Social Constructivist strain of integration theory. Finnemore has suggested that state preferences are formed as a result of "internationally shared norms and values that structure and give meaning to international political life". The constructivist approach is also shared by Shimmelfenig who has sharpened Finnemore's argument by suggesting that the influence of international norms increases or decreases depending on the geographical proximity of the various actors. Lastly, through the Multi-Level Governance framework, Hooghe and Marks have narrowed the focus of constructivists by arguing that international organizations such as the Commission are able to alter the preferences of the member states. Yi has attempted resolve this dilemma by fusing the Liberal Intergovernmentalist and Social Constructivist approaches. In this attempt, the author has suggested that state preferences are both endogenously developed through domestic, political and economic consensus; and exogenously created through regional interactions. While this is an venerable attempt it is vulnerable to the criticims presented above.

${ }^{68}$ Fearon, J., \& Wendt, A. (2002). Rationalism Vs. Constructivism: A Skeptical View. In W. Carlsnaes, T. Risse, \& B. A. Simmons, Handbook of International Relations (pp. 52-73). London: SAGE, 64.

${ }^{69}$ Geddes, B. (2003). Paradigms and Sand Castles: Theory Building and Research Design in Comparative Politics. University of Michigan Press, 177. An example of first order preferences would be that the member states would in general be amicable to the enlargement of the Union however, only on the condition that such widening did not jeopardize their internal economic stability or the functioning of the
} 
Therefore, on the basis of this distinction, the agency mode of delegation presupposes that the second order preferences of the principal are completely developed; and the duties delegated to the agent are created as such that the agent cannot enact outcomes different from the policy preferences of the principal. $^{70}$ This mode of delegation, the author has argued, cannot enhance the credibility of the long-term commitments. $^{71}$ More importantly, here the agents have very little, if any, autonomy; thus, the agency mode is characterized by a rigid structure and a lack of institutional autonomy. However, institutional autonomy, according to Frey, is the single most important characteristic of an actor being able to influence outcomes. ${ }^{72}$ Therefore, functioning in the agency mode, the institution may be able to provide opportunities and incentives, but it would not be able to shape the strategies for the attainment of the given policy objectives. $^{73}$

EU as a whole. Therefore, by dividing state preferences in these two categories one can avoid the "why" question (Why did the member states decide to accept the CEECs?), and in turn focus more freely on the "how" question (How did the member states agree to accept the CEECs?). It should be noted however, that the concept of state preferences is here only employed as a supporting contribution to the discussion of the principal-agent framework. This is because the concept of preferences, while theoretically important, is rather difficult to operationalize, which is due to the complex nature of the information required for its through evaluation. This, among others, includes the revelation of sensitive state interests with respect to all economic and geopolitical consideration. Consequently, while multiplicities of competing factors play a fundamental role in generating the necessary pressure for the emergence of first order preferences, second order preferences are developed in a more isolated environment. This is located mainly within the limited parameters of the interaction between the Commission, the member states and the candidate states, where this interaction is carried out on the basis of the institutional exchange of information, which is unequally available to each of the parties to this interaction.

${ }^{70} \mathrm{Ibid}, 65$.

${ }^{71}$ Majone has borrowed the concept of credibility of commitments from the Liberal Intergovernmentalist framework enhanced by Moravcsik (See Moravcsik 1998). According to this principle, supranational institutions are created in order to ensure that the agreements reached between the member states are respected by those very same states (Moravcsik 1998).

${ }^{72}$ Frey, F. W. (1985). The Problem of Actor Designation in Political Analysis. Comparative Politics , 17 (2), 127-152.

${ }^{73}$ Paraskevopoulos, C. (2006). EU Enlargement and Multi-Level Goverannce in European Public PolicyMaking: Actors, Institutions and Learning. In C. Paraskevopoulos, P. Getimis, \& N. Rees, Adapting to EU Multi-Level Governance - Regional and Environmental Policies in Cohesion and CEE Countries (pp. 325). Ashgate. 
Conversely, the fiduciary mode of delegation is characterized by the existence of a "fiduciary relationship between the delegating authority [principal] and the delegate [agent]"; and therefore, the relative independence of the agent from the principal. ${ }^{74}$ However, the more autonomous an agent is, the more it needs to establish its own legitimacy, which can be achieved through the demonstration of distinctive expertise. ${ }^{75}$ This carries the implication that the higher the policy-relevant knowledge, of the supranational body, the easier it is for this body to establish its own legitimacy, where the tools to establish such legitimacy are based on the understanding that the Commission is an epistemic community. As a result, functioning in the fiduciary mode, the Commission would be able to shape the strategies employed in order to achieve the first order preferences of the member states due to its policy-relevant expertise and institutional legitimacy.

The fiduciary mode of delegation also allows for the understanding that the autonomy of the institution has some rather positive effects for the member states. This is in contrast to the polarization of the agent's function that is inherent in the principal-agent framework presented by Pollack, which limits the analytical potential of the principalagent framework for two reasons. First, both shirking and slippage have negative consequences for the principals, thereby eliminating the possibility for the existence of positive effects from the autonomy of the agent. Second, both alternatives imply that the second order preferences of the member states are fully developed at the outset of the policy-making process.

\footnotetext{
${ }_{75}^{74}$ Majone, Delegation of Power and the Feduciary Principle. (Oxford University Press 2005), 63. ${ }^{75}$ Ibid.
} 
In contrast I would suggest that prior to the implementation phase of the policymaking process the second order preferences of the member states are most frequently not fully developed. This is based on the understanding that the strategies to achieve the underlying policy objectives are generated throughout the policy-making process. The culmination of which is the agreement upon the optimal alternatives for implementation, where in some instances - and specifically when the principals delegate duties to the agent in the fiduciary mode - the principals rely more heavily on the agent for generating these optimal alternatives. In these instances of reliance on the agent, the principal is not only aware that the delegation would award the agent with significant autonomy, but also views this autonomy as the raison d'etre for the very delegation of authority to the agent.

A question may be raised with regards to the ability of the member states to control the autonomous actions of the agent functioning under the premise of this third category. In response, it has already been argued that while the Commission may have room for autonomous action, it may impose limitations on itself in order not to overstep the mandate given by its principals. ${ }^{76}$ Such self-imposed limitations are due to the rational anticipation by the agent of possible sanctions imposed by the principals. ${ }^{77}$ As a result, overtly apparent autonomous action by the agent may in fact be covertly influenced by the first order preferences of the principal. ${ }^{78}$

Moreover, the agent is itself constantly aware of the possibility of the application of sanctions through the "existing oversight mechanisms", where the principals are capable of a) monitoring the activity of the agent and b) sanctioning the agent in

\footnotetext{
${ }^{76}$ Pollack, The Engines of Integration? (Oxford University Press 1998).

${ }_{78}^{77}$ Ibid, 222.

${ }^{78}$ Ibid.
} 
instances of more severe misjudgment of principal preferences. ${ }^{79}$ This means that while the Commission may autonomously generate strategies for the attainment of the given policy objectives, it has to ensure that its proposals display a distinct continuity, and are derived, from the first order preferences of the member states.

This alternative understanding of the autonomy of the agent fits well with the basic principal agent model, which suggests that a collective principal would choose to delegate authority to a supranational agent in order to minimize the costs and maximize the gains from mutual cooperation. ${ }^{80}$ However, the discussion of the modes of delegation has illustrated that the principal-agent framework is incomplete in its analytical potential. In turn I have suggested that a third alternative can be added to the understanding of the function of the agent. As a result, the evaluation of the role of the Commission is best carried out on the basis of a theoretical framework that incorporates the basic principleagent model with the modes of delegation of authority. The following section is aimed at providing this framework.

Section IV - The Theoretical Framework for Analysis:

In the previous section I suggested that a comprehensive analysis of the function of an agent must incorporate the principal-agent framework along with the modes of delegation of authority. There, I also illustrated that one of the factors for this incorporation is based on the understanding that the fiduciary mode of delegation provides an alternative category where the autonomy of the agent has positive consequences for the principal. In this section I will identify the second factor that prompts the conglomeration of these two theoretical perspectives.

\footnotetext{
${ }^{79}$ Pollack, The Commission as an Agent. (Macmillan 2000).

${ }^{80}$ Pollack, The Commission as an Agent (Macmillan 2000), 113.
} 
This is based on the need to identify the conditions under which the agent is delegated duties in either of the modes of delegation. At its most basic incarnation, whether the institution functions in the agency or fiduciary modes depends on the "external opportunities" provided by the principals and on the "internal capabilities" of the institution. ${ }^{81}$ As a result, depending on the particular circumstances, the Commission can function either in agency or in fiduciary modes, thereby displaying "both [purely] agential and [relatively] independent behavior". ${ }^{82}$ Consequently, the question becomes: Under what circumstances do the member states delegate authority to the Commission?

This is also where Pollacks' principal-agent framework proves particularly useful. Recalling the primary factors that explain the autonomy and influence of the supranational agent, we can extrapolate that the Commission is being delegated duties on the basis of the distribution of preferences, the distribution of information and the institutional decision-making rules. ${ }^{83}$ Therefore, the agency mode of delegation is employed by the principals in the instances where: a) the costs of identifying and negotiating common strategies are low, b) the informational asymmetry between the principal and the agent is also low and c) the agent does not already possess distinct competencies. Conversely, the principals employ the fiduciary mode of delegation when: a) the transaction costs for identifying and negotiating common strategies are high, b) the

\footnotetext{
${ }^{81}$ Bretherton, C., \& Vogler, J. (1999). Actors and actorness in global politics: Locating the European Union. In The European Union as a Global Actor (pp. 15-46). Routledge, 29.

${ }^{82}$ Frey, The Problem of Actor Designation in Political Analysis. (1985), 146.

${ }^{83}$ One may notice that there are only three factors included in the present enumeration, and contrast this with the fact that Pollack originally proposes the existence of four such factors. This is due to the fact that, for the purposes of this paper, the factor related to the "existence and utilization of transnational constituencies of sub-national organizations" is intimately related to the one identifying the informational asymmetry between the agent and the principals. This is not to suggest that this factor is of no importance. Rather it means that the limitations of this paper preclude the evaluation of the interaction between the Commission and such transnational constituencies. Consequently, their existence here is understood as a contributing source of information for the supranational institution.
} 
informational asymmetry is also high and in favor of the agent, and c) the agent already has been awarded distinct competencies.

This illustrates that on the basis of the principal-agent framework we can identify three variables, which determine the mode of delegation of authority from the principals to the agent. The first variable is thus, the transaction costs for identifying and negotiating common strategies; the second is the informational asymmetry between the Commission and the member states; and the third is the distribution of competencies between the principals and the agent. Consequently, given the varying nature of delegation by the principals and the potential for oscillating autonomy of the agent, we can ask: How can we best conceptualize the role of the European Commission?

In the instances where the principal exhibits autonomy from its external environment and its internal constituency ${ }^{, 84}$ and the agent functions in the agency mode, the principal is an autonomous body that makes decisions, whereas the agent is a body that is employed by the principal in order to implement the former's decisions. ${ }^{85}$ In order to describe the Commission in this scenario, Hooghe borrows from Page the understanding of administration. That is the implementation and monitoring as performed by the agent. ${ }^{86}$ In Page's view this involves: "obeying orders, following instructions, enforcing regulations, reacting to events and changes in the world outside on the basis of written rules $"{ }^{87}$ Thus, Hooghe suggests that in this scenario the agent is best described as

\footnotetext{
${ }^{84}$ Bretherton, \& Vogler, Actors and actorness in global politics (Routledge 1999), 20.

${ }^{85}$ Hooghe, Principal or Agent. (Cambridge University Press 2001).

${ }^{86}$ Ibid.

${ }^{87}$ Page, E. C. (1997). People Who Run Europe. Oxford: Claredon/Oxford University Press, 148. As quoted by Hooghe.
} 
an administrator of the delegated authority, and its capacity is simply that of a "routine administrator". 88

Conversely, in the instances where the institution functions in the fiduciary mode, the Commission minimizes the transaction costs and ensures the credibility of commitments of the decision-making process. ${ }^{89}$ Consequently the monitoring and implementation carried out by the agent is characterized by relative autonomy. Therefore, the Commission has the right to participate in policy-making, while it is also responsible to the member states for its proposals. ${ }^{90}$ As a result, the member states allow the agent to participate in the policy-making process because the agent is perceived as an epistemic community with an authoritative, and legitimate, claim to knowledge and expertise. ${ }^{91}$ In this capacity the institution is best described as a "bureaucratic entrepreneur". 92

Whether the institution functions in either of these two capacities depends on the modes of delegation identified by Majone, which in turn depend on the three variables explaining the autonomy and influence of the institution. The following table illustrates this dependency and its outcomes.

\begin{tabular}{|l|l|l|}
\hline \multicolumn{3}{|l|}{ Table I. The analytical path to identifying the role of the European Commission. } \\
\hline Transaction costs: & $\begin{array}{l}\text { High costs for identifying and } \\
\text { negotiating common strategies. }\end{array}$ & $\begin{array}{l}\text { Low costs for identifying } \\
\text { and negotiating common } \\
\text { strategies. }\end{array}$ \\
\hline $\begin{array}{l}\text { Distribution of the } \\
\text { informational } \\
\text { asymmetry: }\end{array}$ & $\begin{array}{l}\text { Member states possess relatively } \\
\text { little policy-relevant information - } \\
\text { high informational asymmetry. }\end{array}$ & $\begin{array}{l}\text { Member states have } \\
\text { significant policy-relevant } \\
\text { information - low } \\
\text { informational asymmetry. }\end{array}$ \\
\hline $\begin{array}{l}\text { Distribution of } \\
\text { competencies: }\end{array}$ & $\begin{array}{l}\text { The Commission has more } \\
\text { competencies - Pillar I issues. }\end{array}$ & $\begin{array}{l}\text { The Commission has less } \\
\text { competencies - Pillars II }\end{array}$ \\
\hline
\end{tabular}

\footnotetext{
${ }^{88}$ Hooghe, Principal or Agent. (Cambridge University Press 2001), 155.

${ }^{89}$ Majone, Delegation of Power and the Feduciary Principle (Oxford University Press 2005).

${ }^{90}$ Bretherton, \& Vogler, Actors and actorness in global politics (Routledge 1999).

${ }^{91}$ Hooghe, Principal or Agent. (Cambridge University Press 2001).

92 Ibid, 155.
} 


\begin{tabular}{|l|l|l|}
\hline & & and III. \\
\hline Mode of delegation: & $\begin{array}{l}\text { Member states delegate authority } \\
\text { under the fiduciary mode of } \\
\text { delegation.3 }\end{array}$ & $\begin{array}{l}\text { Member states delegate } \\
\text { authority under the agency } \\
\text { mode of delegation. }\end{array}$ \\
\hline $\begin{array}{l}\text { Role of the } \\
\text { Commission: }\end{array}$ & Bureaucratic entrepreneur. & Routine administrator. \\
\hline
\end{tabular}

Consequently, we can identify two ideal scenarios. In the first scenario: The principals are not faced with complex policy environment and are thus not in need of expert assistance for making decisions. The member states are not experiencing difficulties agreeing on the strategies for the implementation of their first order preferences. The Commission is not in possession of more pertinent policy-specific information, the member states are not faced with budgetary restrictions and therefore the informational asymmetry does not favor the Commission. The Commission does not hold distinct competencies and the decision-making process allows the principals to monitor the agent more thoroughly. As a result the Commission is not delegated duties under the fiduciary mode, rather delegation occurs under the agency mode.

In the second scenario: The member states are faced with complex policy environments and therefore require the assistance of experts in order to make adequate decisions. The multiplicity of strongly held second order preferences complicates the negotiation process and thus agreement cannot be reached. The principals are also not able to gather sufficient policy-specific information, thus the informational asymmetry favors the agent more heavily. The agent has distinct competencies and the decisionmaking process does not allow the principals to monitor the agent extensively, such as

\footnotetext{
${ }^{93}$ It should be noted however, that in some instances the member states might be completely unwilling to delegate duties to the Commission under the fiduciary mode of delegation even when the circumstance suggests that such delegation would lead to optimal outcomes. This is not necessarily the case within the policy of enlargement; rather such behavior is most likely to be anticipated in areas where the member states are jealously guarding their competencies.
} 
QMV. Consequently, the agent is delegated duties under the fiduciary mode. Therefore in this scenario, the Commission is able to shape the strategies that the member states employ in order to achieve their first order preferences.

These two scenarios form the basis for the following empirical evaluation. As such, the analysis will employ government documents and personal interviews with officials from both the Commission and the member states. The content of these documents will be discussed, thereby illuminating the distribution of the three variables, which will consequently determine the role of the Commission at each stage of the enlargement process. 


\section{Chapter II: The Pre-Negotiation Stage}

The pre-negotiation stage of the enlargement process of the European Union met its historic beginning with the signing of the Association Agreements between the EU and the Countries of Central and Eastern Europe. These agreements, which were later called Europe Agreements, were succeeded by the historic offer made by the EU at the Copenhagen European Council in 1993. At this meeting the Union offered the CEECs membership "even before they had applied for it".

For some countries the Copenhagen criteria were established following their signing on to the Europe Agreements, for Bulgaria and Romania these were chronologically subsequent to the latter offer of membership. The Copenhagen criteria set out the basic requirements that the candidate states would have to fulfill if they were to become full members of the Union. These required the CEECs to have "achieved stability of institutions guaranteeing democracy, the rule of law, human rights and respect for and protection of minorities, the existence of a functioning market economy as well as the capacity to cope with competitive pressure and market forces within the Union". ${ }^{2}$ The most significant such requirement was the application of all measures required for the functioning of the single market. ${ }^{3}$ It is important to note that immediately following its creation the Copenhagen criteria became the basic foundation upon which all the remaining accession preparations were developed.

Following the creation of the Copenhagen criteria a number of developments took place prior to the beginning of the accession negotiations. The signing of the Europe

\footnotetext{
1 Graham Avery, "The Enlargement Negotiations," Fraser Cameron, The Future of Europe - Integration and Enlargement (Routledge, 2004) 35-63, 36.

${ }^{2}$ European Council, Conclusions of the Presidency, European Council (Copenhagen, June 1993), 14.

${ }^{3}$ Avery, "The Enlargement Negotiations," (2004) 35-63.
} 
Agreements, the creation of the pre-accession strategy, the white paper on the inclusion of the CEECs into the internal market, the preparation of Agenda 2000, and - particularly for Bulgaria and Romania - the period between the 1997 Luxemburg and 1999 Helsinki European Council meetings. These are at the focus of this chapter. As such, in this chapter I will provide an overview of these developments and present an empirical analysis of the role of the European Commission at each of these milestones along the process.

Section I- The Europe Agreements:

The Rome European Council began the process of establishing and concluding the Europe Agreements in December of 1990. At this meeting the European Council stated that these agreements would "mark a new stage in the Community Policy of developing increasingly close relations with those countries" of Central and Eastern Europe. ${ }^{4}$ Consequently, the 1993 Copenhagen European Council established that the Europe Agreements would set up the "framework for a strengthened dialogue and consultation on matters of common interest". 5

To this effect the European Commission proposed the draft on the conclusion of the Europe Agreements with Romania in $1992^{6}$ and Bulgaria in $1993 .{ }^{7}$ It would have been most beneficial, for the purposes of evaluation, to be able to examine these documents and compare them to the final texts of the Europe Agreements. However,

\footnotetext{
${ }^{4}$ European Council, Presidency Conclusions (part 2) concerning relations with the Soviet Union and the countries of Central and Eastern Europe, European Council (Rome, December 1990), 5.

${ }_{5}^{5}$ European Council, Conclusions of the Presidency, European Council (Copenhagen, June 1993), 28.

6 Commission, "Proposal for a COUNCIL AND COMMISSION DECISION on the conclusion of the Europe Agreement between the European Communities and their Member States, of the one part, and Romania, of the other part," European Commission, 21/12/1992 .

7 Commission, "Proposal for a COUNCIL AND COMMISSION DECISION on the conclusion of the Europe Agreement between the European Communities and their Member States, of the one part, and Bulgaria, of the other part." European Commission, 18/02/1993.
} 
neither of these proposals are available for review. Nevertheless, it can be observed through the Community Pre-Lex ${ }^{8}$ database that the process of assent by the Council took longer in the Romanian case than in the Bulgarian one. This was due to a number of amendments that were proposed by the European Parliament. ${ }^{9}$ These amendments were concerned with the areas of: youth and culture, transport, external economic relations, and foreign affairs. ${ }^{10}$ Unfortunately, these documents are not available for review and as a result it cannot be ascertained if any substantial alterations have been made. Following the amendment proposals by the EP, the Council approved the text of the Europe Agreements for both candidate countries in December of 1994.

Mayhew has illustrated an additional aspect of the function of the Commission in this process. This author has suggested that the negotiating mandate presented by the Commission for the Europe Agreements was generally not opposed by the member states with the exception of the Mediterranean members which were demanding that funding "for the Mediterranean should be at least as high as that for Central and Eastern Europe". ${ }^{11}$ This illustrates that it was the Commission that took the role for negotiating the texts of the Europe Agreements. This in turn suggests that there were high negotiation related transaction costs in preparing the Europe Agreements. However Mayhew does not provide any further detail as to how this role was attributed or carried out by the institution.

\footnotetext{
${ }^{8}$ This is a web-based search engine that offers detailed information regarding the decision-making process between the various institutions. As such, this service monitors the path of legislation from its inception until its conclusion.

Commission, PreLex, European Commission, $<$ http://ec.europa.eu/prelex/detail_dossier_real.cfm?CL=en\&DosId=103440>.

${ }^{10}$ To the detriment of the analytical exercise undertaken in this paper these documents are also not available for examination.

11 Alan Mayhew, Recreating Europe - The European Union's Policy towards Central and Eastern Europe (Cambridge University Press, 1998), 22.
} 
The Europe Agreements established the framework for political dialogue and were intended to "provide an appropriate framework for the gradual integration" of the two countries into the EU. ${ }^{12}$ The political dialogue envisioned through these agreements was to facilitate the full integration of those countries into the Community through the convergence of positions and policies. ${ }^{13}$ The establishment of the political dialogue saw the creation of a forum for the meeting at the ministerial level between the candidate states and the member states under the title of Association Councils. These meetings would generate decisions with respect to the various components of the Europe Agreements and would monitor the progress of the candidate states in assuming their obligations under the framework of the agreements.

While the Europe Agreements fell significantly short from the candidate states' aspirations for membership, there appears to be agreement among scholars that the signing of the Europe Agreements paved the way for the candidate states of Central and Eastern Europe to become full members of the EU. ${ }^{14}$ Consequently, the Europe Agreements signed in the 1990s with the ten CEECs and the Association Agreements

12 Council, "94/907/EC, ECSC, Euratom: Council and Commission Decision of 19 December 1994 on the conclusion of the Europe Agreement between the European Communities and their Member States, of the one part, and Romania, of the other part.," 31 December 1994, Eur-Lex, Council, 27 July 2010 http//eurlex.europa eu LexUriServLexUriServ.do?uri-CELEX:31994D0907:EN:HTML; Council, "94/908/EC. ECSC, Euratom: Decision of the Council and the Commission of 19 December 1994 on the conclusion of the Europe Agreement between the European Communities and their Member States, of the one part, and the Republic of Bulgaria, of the other part." 19 December 1994, Eur-Lex, Council, 27 July 2010 $<$ http://eur-lex.europa.eu/LexUriServ/LexUriServ.do?uri=CELEX:31994D0908:EN:HTML

${ }_{13}^{13}$ Council, Europe Agreement with Bulgaria, 1994; Council, Europe Agreement with Romania, 1994.

14 Graham Avery, "The Enlargement Negotiations," Fraser Cameron, The Future of Europe - Integration and Enlargement (Routledge, 2004) 35-63; Mayhew, Recreating Europe - The European Union's Policy towards Central and Eastern Europe, 1998; Snejana Maleeva, "Bulgaria's Accession to the European Union," Nanette Neuwahl, European Union Enlargement - Law and Socio-Economic Changes (les edition themis, 2003) 255-265. 
signed with Cyprus and Malta in the 1970s served as the legal basis for the relationship between the EU and the future candidate states. ${ }^{15}$

One of the more important components of these agreements was the approximation of laws between the candidate states and the Community, which was the result of the explicit requirement for the application of the entire acquis communautaire by the candidate states at the time of accession. This chapter of the agreements stated that the candidate states would "endeavor to ensure that [their] legislation will be gradually made compatible with that of the Community". ${ }^{16}$ The Community would offer the candidate states assistance in accomplishing this task through various mechanisms, such as the exchange of experts, the provision of early information regarding new legislation, the organization of seminars and the provision of training activities. ${ }^{17}$ The remainder of the Europe Agreements covered issues of trade expansion, economic, social, financial, and cultural cooperation. ${ }^{18}$ These sectors were divided into separate chapters within the agreements where the abolition of customs duties and trade barriers were spelled out explicitly for each sector.

The Europe Agreements were a pivotal beginning of the journey towards accession for the candidate states. As such, they form a component of the pre-negotiation stage of the accession process and are thus subject to empirical analysis. The first criterion for this evaluation is the transaction costs for identifying and negotiating common strategies. With respect to this variable the transaction costs are information

${ }^{15}$ Commission, "EUROPA," 2001, Enlargement of the European Union - An historic opportunity, EuropeanCommission,02 April 2009

$<$ http://ec.europa.eu/enlargement/archives/pdf/press_corner/publications/corpus_en.pdf $>$.

${ }^{16}$ Ibid, 29.

${ }^{17}$ Ibid.

${ }^{18}$ Ibid. 
related due to the complex policy environment resulting from the need to bridge the plethora of policies enumerated within the various articles and protocols of the Agreements. Consequently, while there were no apparent commitment related costs and the information regarding the negotiation costs comes from a secondary source - rather than the evaluation of the primary documents - it can be concluded that there were only moderately high transactions costs.

The second variable for evaluation is the informational asymmetry between the member states and the Commission. For this variable no information exists that may conclusively prove that the member states had little or significant policy-relevant information. The only indication that the member states may not have been in possession of significant such information is the fact that the Commission had submitted to the 1992 Lisbon European Council a communication titled: "Europe and the Challenge of Enlargement". Nevertheless, this communication did not discuss the Europe Agreements in length. ${ }^{19}$ Therefore, it can be concluded that there is little, if any, evidence allowing for a conclusive discussion of the second variable.

Similarly to the previous variable, there is inconclusive information regarding the third requirement related to the areas of institutional competencies. This again is due to the fact that the original proposals of the text of the Europe Agreements prepared by the Commission are not available. It is worth however, to note that these Agreements included policies that span all three (former) Pillars of the EU policy structure, thus suggesting that even if the original documents were available, a researcher may not be in

19 Commission, Europe and the Challange of Enlargement, European Commission (Brussels: European Commission, June 1992). 
a position to determine whether the Europe Agreements as such fall under the competencies of either the member states or the Commission.

Finally, the analysis of this phase of the enlargement process illustrates that the Commission has been delegated the duties to prepare the Europe Agreements in the fiduciary mode. This is further evidenced by the fact that the 1992 Lisbon European Council had asked the supranational institution to monitor the progress for the Europe Agreements, and to "suggest further steps as appropriate". ${ }^{20}$ To this request, the European Council in Edinburgh added another. It invited the Commission to propose a communication on the basis of which the Europe Agreements could be concluded. ${ }^{21}$

Despite the fiduciary nature of the delegated duties, given the limitations imposed by the lack of availability of documentation regarding the establishment and conclusion of the Europe Agreements the analysis of the role of the Commission at this phase of the pre-negotiation stage of the accession process can be characterized as superficial at best. This is because there is no explicit evidence suggesting that the Commission was able to shape the second order preferences of the member states. This means that it is fruitless to draw specific conclusions regarding the ability of the Commission to influence the second order preferences of the member states at this phase. Nevertheless, it is important to mention that the requirements for the characterization of bureaucratic entrepreneur are more extensively satisfied than the ones pointing to the routine administrator characterization.

20 European Council, Presidency Conclusions, European Council (Lisbon: European Parliament, June 1992), 7.

21 European Council, Presidency Conclusions, European Council (Edinburgh: European Parliament, December 1992). 
Section II - The Pre-Accession Strategy:

The adoption of the Europe Agreements was precluded by the Corfu June 1994 European Council. At this meeting the presidency conclusions invited "the Commission to make specific proposals as soon as possible for the further implementation of the Europe Agreements". ${ }^{22}$ At this request the Commission prepared a communication titled: The Europe Agreements and Beyond: A Strategy to prepare the Countries of Central and Eastern Europe for Accession. ${ }^{23}$ This communication set out the strategy for cooperation in the areas of Common Foreign and Security Policy (CFSP), Justice and Home Affairs (JHA), the internal market, social policy, trade, agriculture, legal approximation and financial assistance. In addition, it was within this communication that the varying pace of the accession negotiations was embedded. ${ }^{24}$ As a response to this communication the Council, at its July $18^{\text {th }} 1994$ meeting, provided its "broad support for the ideas set out in the Commission's communication". ${ }^{25}$

Following this de facto approval by the Council the Commission, on July $27^{\text {th }}$ 1994, presented a more detailed communication elaborating on the points presented as the pre-accession strategy. ${ }^{26}$ This was subsequently discussed at the Council meeting of October $4^{\text {th }} 1994$, where the Council concluded that the Commission's proposals

\footnotetext{
${ }^{22}$ European Council, Presidency Conclusions, European Council (Corfu: European Council, June 1994), 13.

${ }^{23}$ Commission, The Europe Agreements and Beyond: A Strategy to Prepare the Countries of Central and Eastern Europe for Accession, European Commission (Brussels: European Commission, July 1994).

${ }^{24}$ Michael J Baun, A Wider Europe: The Process and Politics of European Union Enlargement (Rowman \& Littlefield Publishers Inc., 2000).

${ }^{25}$ Council, 1778TH COUNCIL MEETING - GENERAL AFFAIRS, Press Release, Council of Ministers (Brussels: Council of Ministers, July 18th 1994).

26 Commission, Follow up to Commission Communication on "The Europe Agreements and Beyond: A Strategy to Prepare the Countries of Central and Eastern Europe for Accession", European Commission (Brussels: European Commission, July 27th 1994).
} 
"provide a good basis for further reflections for the European Council in Essen". ${ }^{27}$ For this meeting of the heads of state the Council further discussed the pre-accession strategy at its following meeting on October $31^{\text {st }} 1994$. This then formed the basis on which the Council presented to the European Council the strategy for approval. Consequently, the Essen European Council, held in December of 1994, approved the pre-accession strategy, which was to be "politically implemented by the creation... of structured relations" between the EU and the candidate states. ${ }^{28}$ The basis for this structured relationship was the Europe Agreements.

In order to evaluate the role of the institution at this stage of the process, it is most beneficial to analyze the contents of the two communications from the Commission and juxtapose this with the final text approved by the Essen European Council. The initial communication was rather basic and therefore inherently limited in its proposals. Nevertheless, here the Commission established that the structured relationship between the EU, its institutions, and the candidate states should stretch through not only the Community competencies but should also include interaction within JHA and the CFSP. $^{29}$

According to the Commission the already existing such structured relationship incarnated within the Europe Agreements - was limited to "two informal meetings" and therefore insufficient. ${ }^{30}$ As a result, the supranational institution suggested that this dialogue should be broadened significantly. In this same communication the Commission

27 Council, 1790E SESSION DU CONSEIL - AFFAIRES GENERALES, Press Release, Council of Ministers (Luxemburg: Council of Ministers, October 4th 1994). Translated from French by the author.

${ }_{28}$ European Council, Presidency Conclusions, Euroepan Council (Essen: European Council, December 1994).

${ }^{29}$ Commission, The Europe Agreements and Beyond, July 1994.

${ }^{30} \mathrm{Ibid}, 2$. 
stressed the importance of the progressive integration of the candidate states into the internal market of the Union. ${ }^{31}$ These proposals and suggestions were then elaborated upon by the follow-up communication in July of $1994 .{ }^{32}$

In the first part of this second communication the Commission proposed the specific tools for establishing the structured relationship. These included: joint meetings at the General Affairs Council level; sectoral meetings in the areas of the energy, environment and telecommunications; meetings at the Council level in the areas of the economy, the internal market, social policy, culture, and youth and health. ${ }^{33}$ The Commission also elaborated on the areas of cooperation under JHA, such as immigration and asylum, drugs, and judicial and police cooperation. ${ }^{34}$

In the second part of this document, the Commission stressed the importance of the "alignment of their [the CEECs] economic and regulatory structures with those of the Union". ${ }^{35}$ The most important category of which was the approximation of laws relating to the internal market. This alignment, the Commission suggested, should be done at the pace of the candidate states, which were to prepare individual timetables for the approximation of legislation. ${ }^{36}$ The remainder of the second part of this communication enumerated the various requirements for the successful inclusion of the candidate states into the internal market.

It was these two reports prepared by the Commission that were reviewed by the General Affairs Council. As a result, the Council submitted to the Essen European

\footnotetext{
${ }^{31}$ Ibid.

${ }^{32}$ Commission, Follow up to Commission Communication, (July 27th 1994).

${ }^{33}$ Ibid.

${ }^{34}$ Ibid.

${ }^{35}$ Ibid, 5 .

${ }^{36}$ Ibid.
} 
Council a report on the pre-accession strategy. This report, although not verbatim, did include all of the proposals made by the Commission in its follow-up communication. Even in the area of CFSP the Council suggested that the candidate states be offered the ability to associate themselves with the decisions of the Union in CFSP matters. ${ }^{37}$ This proposition simply restated the Commission's initial suggestion.

Consequently, the European Council in Essen approved the pre-accession strategy as it was outlined by the Council in its report. More importantly, the European Council stated that the "key element in the strategy [was] to narrow the gap [between the member states and the candidate states] in preparation of the associated states for integration into the internal market". ${ }^{38}$ This was essentially the progressive alignment of rules and regulations related to the internal market, proposed by the Commission.

Following the adoption of the pre-accession strategy by the Essen European Council, the General Affairs Council at its meeting in February of 1995 prepared a work program for the relations with the CEECs. ${ }^{39}$ This program presented a timetable for the structured dialogue meetings to occur. The scheduled discussions outlined by the Council, closely followed the requirements set out by the pre-accession strategy and therefore invariably mimicked the proposals presented by the Commission in its communication.

This phase of the pre-negotiation stage avails itself to a more comprehensive analysis than the phase examined previously. ${ }^{40}$ This is due to the fact that far more information is available regarding the exchanges that have occurred between the

\footnotetext{
${ }^{37}$ European Council, Presidency Conclusions, (December 1994).

${ }^{38}$ Ibid, 10.

39 Council, 1827TH COUNCIL MEETING - GENERAL AFFAIRS, Press Release, Council of Ministers (Brussels: Council of Ministers, February 6th 1995).

${ }^{40}$ The phase discussing the Europe Agreements.
} 
Commission and the member states. Consequently, following the basic theoretical framework for analysis the first variable that is examined is the transaction costs for identifying and negotiating common strategies.

In this respect there is marginal evidence suggesting the existence of commitment related transaction costs. This is inferred from the declaration of the Commission that the member states had not taken full advantage of the processes available for the existence of a structured dialogue. ${ }^{41}$ Indeed this does not suggest that there were high commitment related costs with distinct certainty. Nevertheless, it does point in this direction more convincingly than the alternative - of low commitment related costs. With respect to the information related transaction costs, the evidence overwhelmingly intimates that they were indeed high. The encompassing nature of the pre-accession strategy - including the various aspects of the internal market as well as the policy areas under JHA and CFSP illustrate that the policy environment, which the Commission was required to navigate, was in fact quite complex. Lastly, there is some evidence suggesting the existence of low negotiation related transaction costs. This is manifested in the member state centered nature of the proposed structured relationship, which propose that this dialogue should be carried out between the various Council formations and the respective representatives of the candidate states.

Consequently, the conclusions regarding the first variable are: a) moderate commitment related costs, b) high information related transaction costs and c) low negotiation related costs. Overall, the scales of this variable favor the general conclusion that there were moderate to high transaction costs inherent in this phase of the process.

41 Commission, The Europe Agreements and Beyond, (July 1994). 
The second variable evaluating the level of the informational asymmetry between the Commission and the member states is not very well illustrated throughout this phase. Nevertheless, it does appear that there was a relatively low informational asymmetry. This is due to two factors. First, the proposals of the Commission related to the structured relationship were already developed, albeit in different format, under the existing procedures of the Europe Agreements. Second, the Copenhagen European Council discussed the assertions regarding the importance of the approximation of laws and the inclusion of the candidate states into the internal market of the Union in 1993, thus the function of the Commission in preparing the pre-accession strategy was the transformation of these criteria into a strategic format. With respect to the third variable, it can be observed that the nature of the pre-accession strategy did not favor the competencies of either the member states or the Commission. This is due to the overarching format of the strategy, which included both type of competencies. Therefore, a definitive conclusion regarding this variable cannot be drawn.

Lastly, the evidence presented in this section suggests that the Commission was delegated the duties to prepare the pre-accession strategy under the fiduciary mode. This is supported by the vague nature of the request by the European Council at Corfu, which illustrates that the member states were not aware of the form in which such a strategy should be developed. ${ }^{42}$ The only certainty from the side of the member states was that the starting point of the creation of the strategy should be the already existing Europe Agreements.

As a result the overall evaluation of this phase of the pre-negotiation process has illustrated that there is sufficient evidence suggesting that the institution has been able to

\footnotetext{
${ }^{42}$ See page 43
} 
develop the first order preferences of the member states - which identified the necessity for "further implementation of the Europe Agreements" - into a definitive strategy for the accomplishment of this objective, thereby shaping the member states' second order preferences. Consequently, the role of the supranational institution is best described as a bureaucratic entrepreneur.

Section III - The White Paper:

The pre-accession strategy developed by the Commission and approved by the European Council at Essen in December of 1994 identified the importance of the gradual inclusion of the candidate states into the internal market of the European Union. In this respect the Essen European Council requested that the Commission should submit a White Paper outlining a detailed strategy for the adoption of the internal market related rules and regulations by the candidate states. ${ }^{43}$ The General Affairs Council in December of 1994 confirmed the importance of this request by stating that the Commission should "submit as soon as possible its proposals for the White Paper on the integration of the CCEE [Countries of Central and Eastern Europe] into the internal market". "The priority of creating this document was restated by the Council at its meeting in January of $1995 .^{45}$

Pressured by this expression of political will, the Commission prepared the White Paper, titled: "Preparation of the Associated Countries of Central and Eastern Europe for Integration into the Internal Market of the Union", and presented this to the Council

\footnotetext{
43 European Council, Presidency Conclusions, (December 1994).

44 Council, 1820TH COUNCIL MEETING - GENERAL AFFAIRS, Council of Ministers (Brussles: Council of Ministers, December 19/20 1994).

45 Council, 1825TH COUNCIL MEETING - GENERAL AFFAIRS, Council of Ministers (Brussles: Council of Ministers, January 23rd 1995).
} 
on May $3{ }^{\text {rd }}$ of $1995 .{ }^{46}$ Baun has identified three main achievements of the White paper: a) it identified the important legislation (elements of the acquis) to be adopted by the CEECs in each of the economic sectors, simultaneously suggesting the proper order for the legislative transposition, b) it emphasized the necessary legal and administrative infrastructure in order to ensure that the minimum standards for products were met, and c) outlined the various forms of financial and technical support that was available to the CEECs. ${ }^{47}$ It is important to note that in preparation of the White Paper the Commission held sector-by-sector bilateral, as well as multilateral, discussions with the candidate states. ${ }^{48}$ The White Paper was a component of the previously discussed pre-accession strategy, however it went beyond this previous communication by identifying "key measures in each sector of the internal market and suggest[ed] a sequence in which the approximation of legislation should be tackled". ${ }^{49}$

The White Paper also stressed the importance of the establishment of the requisite administrative structures, which were to allow for the successful implementation and enforcement of the adopted rules and regulations. ${ }^{50}$ The Commission also outlined the need for enhancing the already existing assistance to the candidate states, most notably through PHARE. ${ }^{51}$ The institution suggested that the level of technical assistance to the candidate states should be deepened through the establishment of an information exchange office, which was to be "managed by the Commission and supported by a

\footnotetext{
${ }^{46}$ Commission, White Paper - Preparation of the Associated Countries of Central and Eastern Europe for Integration into the Internal Market of the Union, European Commission (Brussels: European Commission, May 3rd 1995).

${ }^{47}$ Baun, A Wider Europe, (2000).

${ }^{48}$ Ibid.

${ }^{49} \mathrm{Ibid}, 2$.

${ }^{50}$ Ibid.

${ }^{51}$ Ibid.
} 
multi-country PHARE programme (sic)".52 The responsibility for providing this technical assistance would be shared between the Commission, the member states and private bodies. $^{53}$

Finally, the Commission set out some key responsibilities for itself as well as the member states arising form the recommendations presented in the White Paper. The most notable such duties for the supranational institution were: to hold consultations with the candidate states on the various points of recommendation; to set up the technical assistance office and arrange the coordination of the assistance provided; to keep the candidate states informed on matters related to the internal market; and lastly, to keep the member states informed about the progress of the candidate states. With respect to the responsibilities of the member states, the Commission "invited" them to: "make available expert advice" and to provide the Commission with information regarding the nature of the latter. ${ }^{54}$

The Commission presented the White Paper to the General Affairs Council on May $29^{\text {th }}$ of 1995 . The Council noted the general guidelines that emerged from the discussion of the Permanent Representatives and decided that a final conclusion on the White Paper would be established following the examination of the proposals by the Internal Market Council formation on June $6^{\text {th }}$ of $1995 .^{55}$ At this meeting, the ministers responsible for the internal market discussed the White Paper with their counterparts from the candidate states. The outcome of the discussion was that "all participants welcomed the White Paper" and a consensus was reached on the role of the

\footnotetext{
52 Ibid, 2.

${ }^{53}$ Ibid.

${ }^{54}$ Ibid, 40.

55 Council, 1847TH COUNCIL MEETING - GENERAL AFFAIRS, Council of Ministers (Brussels: Council of Ministers, May 29th 1995).
} 
communication as a component of the pre-accession strategy. ${ }^{56}$ More importantly, the meeting identified "agreement on the approach adopted by the White Paper" and reiterated the role of the candidate states in establishing individual priorities for tackling the adoption of rules within each sector on the basis of the pace of their individual economic reforms. ${ }^{57}$

The Conclusions of this meeting of the Internal Market Council were conveyed to the General Affairs Council, which in return "agreed on the conclusions on the Commission's White paper". ${ }^{58}$ As a consequence, the Council forwarded this communication "for the attention of the Cannes European Council". 59 The Cannes European Council, in June of 1995, "welcomed" the White Paper as a "useful guide" for the candidate states. ${ }^{60}$ The heads of state also approved the emphasis on the importance of the progressive alignment of legislation on the internal market and committed the member states to provide the technical assistance in the fashion proposed by the Commission. ${ }^{61}$ All in all, and perhaps not surprisingly considering the outcomes from the meetings of the Council, the European Council at Cannes approved the White Paper in its de facto entirety. This marks the completion of the process of creating the White Paper and therefore, next we will turn to the empirical analysis of this phase.

Moving onto the empirical analysis, the description of the process for creating and approving the White Paper presented by the Commission has illustrated that the commitment costs associated with the identification and negotiation of common

56 Council, 1851ST COUNCIL MEETING - INTERNAL MARKET, Council of Ministers (Brussels: Council of Ministers, June 6th 1996), 1.

${ }^{57}$ Ibid, 1.

58 Council, 1853TH COUNCIL MEETING - GENERAL AFFAIRS, Council fo Ministers (Brussels: Council of Ministers, June 12th 1995), 4.

${ }^{59}$ Ibid, 4.

${ }^{60}$ European Council, Presidency Conclusions, Eruoepan Council (Cannes: European Council, June 1995).

${ }^{61}$ Ibid. 
strategies were particularly low at this phase of the accession process. The agreement by the member states to provide the necessary technical assistance to the candidate states was made even easier by the fact that the Commission assumed the obligation to coordinate the process. ${ }^{62}$ This minimized the efforts required by the member states, thus fostering an environment where the commitment of the member states was particularly easy to achieve.

Conversely, the information related transaction costs were rather high due to the complex structure and enormous body of legislation that is related to the internal market. Similarly, the negotiation related transaction costs were also high. This was the result of the necessity to prepare a strategy that was universally applicable to all candidate states that have signed Europe Agreements as well as those that were to sign these in the future. ${ }^{63}$ Consequently, the overall evaluation of the first variable suggests that there were relatively high transaction costs, thus satisfying the first requirement for identifying the supranational institution as a bureaucratic entrepreneur.

The analysis related to the second variable also points to the overall entrepreneurial nature of the task carried out by the institution in preparing the White Paper. This variable evaluates the informational asymmetry between the member states and the Commission. In this instance, and unlike the previous phases that were analyzed in this chapter, this second variable is inherently connected to the third variable, examining the distribution of competencies between the member states and the Commission, and as such the two are discussed simultaneously. The distribution of competencies clearly favors the Commission, where the internal market, as a policy field,

62 Commission, White Paper, (May 3rd 1995).

63 Ibid. 
is clearly located within the area of expertise of the Commission. The internal market is also the area where the supranational institution displays the most significant reserves of expert knowledge and expertise. Therefore, it is not surprising that there was a high informational asymmetry in favor of the supranational institution. Consequently, due to these factors, and mainly the result of the definitive institutional expertise of the Commission in the field of the internal market, the member states through the Essen European Council delegated the duties for the preparation of the White Paper in the fiduciary mode. ${ }^{64}$

As a result, it can be observed that the member states delegated some authority to the Commission on the basis of clear preferences - the creation of a detailed strategy for the progressive integration of the candidate states into the internal market. Pursuant of this general objective the Commission presented detailed proposals covering each sector of the internal market and presented those to the member states for review and approval. Consequently, upon this review, the member states approved the institution's proposals as they were presented. Therefore, this phase of the pre-negotiation stage is the most vivid example of the ability of the supranational institution to shape the second order preferences of the member states. Therefore, the role of the Commission at this phase is most explicitly that of a bureaucratic entrepreneur.

Section IV-Agenda 2000:

Prior to the Madrid European Council in December of 1995, both Bulgaria and Romania had submitted their applications for membership. At this meeting the European Council asked the Commission to "take its evaluation ... further [from the White Paper],

${ }^{64}$ European Council, Presidency Conclusions, (December 1994). 
particularly with regard to agricultural and structural policies". ${ }^{65}$ The heads of state also called on the Commission to prepare its opinions on the applications for membership submitted by the candidate states. ${ }^{66}$ The subsequent meeting of the European Council in Florence on June of 1996 reiterated "the need for the Commission's opinions and reports on enlargement ... to be available as soon as possible after the completion of the Intergovernmental Conference [referring to the negotiations resulting in the Treaty of Amsterdam]". ${ }^{67}$ Similarly, the Dublin European Council in December of 1996 confirmed the request initiated at the Madrid meeting. ${ }^{68}$ However, it was not until the following year (1997) that any significant progress had been made with regards to the Enlargement process. Throughout 1996 the Council of Ministers had not discussed any further developments on this process, save for a few meetings on the basis of the structured dialogue established by the pre-accession strategy. This is not surprising however, because the questions of widening were being overshadowed by the questions of deepening arising from the negotiation of the Treaty of Amsterdam.

Consequently, at the June meeting of the European Council in Amsterdam, the heads of state proclaimed that with the "successful conclusion of the IGC, the way [was] now open for launching the enlargement process". 69 This, the European Council acknowledged would commence with the submission of the comprehensive report by the

${ }_{65}$ European Council, Presidency Conclusions, European Council (Madrid: European Council, December 1995), 1.

${ }^{66} \mathrm{Ibid}$.

67 European Council, Presidency Conclusions, European Council (Florence: European Council, June 1996).

${ }^{68}$ European Council, Presidency Conclusions, European Council (Dublin: European Council, December 1996).

69 European Council, Presidency Conclusions, European Council (Amsterdam: European Council, June 1997), 2. 
commission called Agenda $2000 .^{70}$ The heads of state also called on the General Affairs Council to "examine in depth the Commission's opinions as well as its Agenda 2000 communication" and to present a comprehensive report to the European Council at its Luxemburg meeting in December of $1997 .^{71}$

The Commission, in the mean time, had been preparing the Agenda 2000 report, with its final incarnation being established by June of 1997. This communication, titled: "Agenda 2000: For a Stronger and Wider Union", consisted of three major components. ${ }^{72}$ In the first part of the report the Commission presented the response to the European Council's invitation to evaluate the internal policies of the Union. The second part of the report developed the enhanced pre-accession strategy. Lastly, the third component of this communication presented the opinions of the Commission on the accession application by the candidate states. In the following discussion I will outline the basic proposals of the Agenda 2000 report while paying specific attention to the enhanced pre-accession strategy and the Commission's opinions. This is not to suggest that the first component of this communication is irrelevant, rather this is a function of the limitation of the scope of this work, as they have been set out in the introductory chapter. $^{73}$

Within the first part of the report the Commission addressed issues of importance to the internal policies of the Union such as: Economic and Social cohesion, the Common Agricultural Policy, and the necessity for a new financial framework. Among these the institution set out the basic principles behind the strategy for the enlargement process. It

\footnotetext{
${ }^{70}$ Ibid.

${ }^{71}$ Ibid, 2.

72 Commission, Agenda 2000: For a Stronger and Wider Union, European Commission (Brussels: European Commission, June 1997).

${ }^{73}$ See page 7.
} 
was these principles that established the basis for the enhanced pre-accession strategy, and as such, require more detailed attention. According to the Commission "a successful strategy for enlargement ... needs to combine negotiations ...[with] a reinforced preaccession strategy" ${ }^{74}$ The negotiations, it was proposed, were to be based on four basic principles: the assumption of rights and obligations provided under the acquis by the candidate states, the application and enforcement of acquis upon accession, the allowances for "transition measures - but not derogations [in] duly justified cases", and the regular monitoring of the progress of the candidate states through reports prepared by the Commission. ${ }^{75}$

The enhanced pre-accession strategy proposed the abolition of the existing structured dialogue and the insertion of, what the Commission termed, Accession Partnerships. The Accession Partnerships outlined the"short - and medium - term priorities and intermediate objectives". ${ }^{76}$ The main feature of these partnerships was the inclusion of "precise commitments on the part of the applicant country, relating in particular to democracy, macroeconomic stabilization and nuclear safety, as well as a national programme (sic) for the adoption of the Community acquis within a precise timetable, focusing on the priority areas identified in each opinion". ${ }^{77}$ The priorities of these commitments were to be based on the sectors identified as deficient by the Commission's opinions. More importantly, the Accession Partnerships were to "take on the form of a Commission decision". ${ }^{78}$

The outcomes of the progress under these partnerships were to be reported on by

\footnotetext{
${ }_{74}^{74}$ Commission, Agenda 2000, (June 1997), 51.

${ }^{75}$ Ibid, 51.

${ }^{76}$ Baun, A Wider Europe. (2000), 101.

${ }^{77}$ Ibid, 53.

${ }^{78}$ Ibid. 53.
} 
the Commission to the European Council regularly, and beginning in 1998. The enhanced pre-accession strategy was to guide the candidate states in their preparation for membership. ${ }^{79}$ It is important to also note that on the basis of these reports the Commission would recommend that accession negotiations be commenced or not. This brings us to the second part of the Agenda 2000 report, which focuses on a detailed presentation of the enhanced pre-accession strategy.

In addition to the inclusion of the Accession Partnerships discussed previously, the enhanced pre-accession strategy (SPAR) included the extension of participation in community programs to the candidate states. ${ }^{80}$ The method for the application of SPAR was based on two principles: the focus on enlargement priorities and the setting of intermediate objectives. ${ }^{81}$ The first principle involved the reinforcement of the institutional and administrative capacities of the candidate states through training and cooperation with the member states. This also included the application and enforcement of community standards to the various enterprises of the candidate states. The second principle referred to the establishment of timetables for completion of the proposed reforms by the candidate states. ${ }^{82}$ This was of particular importance due to the explicit linkage of financial assistance from the Union to the demonstration of satisfactory conclusion of reforms by the candidate states.

The Accession Partnerships component of SPAR were discussed previously and therefore attention here will rather be awarded to the participation of the candidate states in community programs. This proposal would in effect extend the scope for function of

\footnotetext{
${ }^{79}$ Baun, A Wider Europe, $(2000)$.

${ }^{80}$ Ibid.

${ }^{81}$ Ibid.

${ }^{82}$ Ibid.
} 
the Technical Assistance Information Exchange Office (TAIEX) established under the proposals of the White Paper. ${ }^{83}$ The duties of TAIEX would go beyond the internal market and include the environment and transport. Another outcome of the participation in community programs would be the participation of the candidate states in the various community agencies - such as: Medicines Evaluation, and Environmental Agencies. Lastly, this aspect of SPAR would see the participation of the candidate states into the programs "concerned with administrative cooperation and application of the acquis", thus allowing the candidate states to "obtain accurate information about Community law". ${ }^{84}$

The third component of the Agenda 2000 communication was the opinions of the Commission on the application for membership by the candidate states of Central and Eastern Europe. This analysis was done on the basis of the criteria for membership established by the Copenhagen European Council in 1993, in combination with the legal and administrative capacity of each candidate state, which became a de facto component of the membership criteria following the Madrid European Council meeting. The opinions were generated on the basis of information provided by the candidate states, the member states, the European Parliament, other international organizations, international financial institutions, and the evaluation - by the Commission - of progress made under the Europe Agreements. ${ }^{85}$ In these opinions the Commission analyzed the current situations of each candidate state while "looking forward to the medium term

\footnotetext{
${ }^{83}$ Ibid.

${ }^{84}$ Ibid, 89.

85 Commission, "EUROPA," 2001, Enlargement of the European Union - An historic opportunity, European Commission, 02 April 2009 $<\mathrm{http}: / /$ ec.europa.eu/enlargement/archives/pdf/press_corner/publications/corpus_en.pdf $>$.
} 
prospects". ${ }^{86}$ This forward nature of the evaluation was "unique in the history of $E U$ enlargements". 87

The first part of the Copenhagen requirements was the political criteria. In this respect the Commission concluded that both Bulgaria and Romania were "on the way to satisfying the political criteria" ${ }^{88}$ With regards to the economic criteria, which were the second requirement developed by the 1993 Copenhagen European Council, the circumstances of the two countries diverged. While, Bulgaria, it was concluded, would not be able to cope with the competitive pressures of the market of the Union, Romania would only face "serious difficulties" in assuming this task. ${ }^{89}$

The third component of the Copenhagen criteria was the ability of the candidate states to assume the obligations of the acquis. The analysis of this criterion by the Commission has illustrated that both countries were either entirely not prepared to, or would be facing significant difficulties in, assuming the obligations of membership in every aspect - with the notable exception of the CFSP. Lastly, both countries would be required to enact "a major and sustained effort of reform" in their administrative structures. $^{90}$

On the basis of these conclusions the Commission suggested that neither Bulgaria, nor Romania, were sufficiently prepared to commence accession negotiations. In order to remedy this, the Commission suggested that the enhanced pre-accession strategy is an

\footnotetext{
${ }^{86}$ Commission, Commission Opinion on Bulgaria's Application for Membership of the European Union, European Commission (Brussels: European Commission, July 1997), 118.

87 Heather Grabbe, The EU's Transformative Power - Europeanisation Through Conditionality in Central and Eastern Europe (New York: Palgrave, 2006), 13.

${ }_{88}$ Commission, Opinion on Bulgaria, (July 1997), 119; Commission, Commission Opinion on Romania's Application for Membership of the European Union, European Commission (Brussels: European Commission, July 1997), 111.

${ }^{89}$ Ibid, 111.

${ }^{90}$ Ibid, 113 and 122.
} 
important tool. The Commission's initial opinions provided the authorities of the candidate states with the first impressions on how the national legislation must be altered in order to meet the demands of the implementation of the acquis. ${ }^{91}$ In addition, the initial screening process, identified the level of harmonization of national - candidate states' laws and that of the community, the potential problems, and areas where transition periods may be necessary. ${ }^{92}$ Furthermore, the supranational institution established that it would prepare a report on the progress of each candidate state "no later than the end of $1998, .93$

The Commission presented the complete Agenda 2000 report to the General Affairs Council at its July $22^{\text {nd }}$ of 1997 meeting, at which discussion the Council "agreed to hold general policy debate" at its following meetings. ${ }^{94}$ In the following months the Council had numerous discussions regarding the Agenda 2000 report where final agreement within the Council was established at its December $8^{\text {th }} 1997$ meeting. ${ }^{95}$ The outcome of this final agreement was a detailed report, which was to be submitted to the Luxemburg European Council for final approval. ${ }^{96}$ This report was divided into two parts; the first, examined the proposals of the Commission regarding the enlargement process; the second part analyzed the internal policy proposals of the Commission. ${ }^{97}$ Consequently, it is the first part of the Council's report that is at focus here.

\footnotetext{
91 Ion Serpe, Interview at the Romanian Permanent Representation, Martin Manolov (4 May 2009).

${ }_{92}^{92}$ Baun, $\underline{\text { A Wider Europe, }}$ (2000).

${ }_{93}^{93}$ Ibid, 114 and 123.

94 Council, 2024th GENERAL AFFAIRS - COUNCIL CONCLUSIONS, Council of Ministers (Brussels: Council of Ministers, July 1997), 1.

95 Council, 2057th GENERAL AFFAIRS - COUNCIL CONCLUSIONS, Council of Ministers (Brussels: Council of Ministers, December 1997).

96 Council, Presidency report to the European Council on enlargement of the Union and Agenda 2000 , Council of Minisers (Brussels: European Parliament, December 1997).

${ }^{97}$ It should be noted that this report also included a Annex discussing the strategy for the carrying out of the negotiation process, however this will be discussed in detail in the following chapter and as such, is not evaluated here.
} 
In this report the Council generally accepted the proposed structure and function of the enhanced pre-accession strategy. However, with respect to the Accession Partnerships the Council pointed out the need for the member states to be more involved in this process and as such, the Council stated that it "reserves the right to intervene at the most significant stages of the partnerships". ${ }^{98}$ Moreover, the Council also stated that it is the body that "will have to decide unanimously on the principles underlying the partnerships as the key element in the pre-accession strategy. On this basis it will then decide, by a qualified majority and by 15 March 1998 at the latest, on the principles, priorities, intermediate objectives, significant adjustments and conditions applicable to each individual partnership". 99

Conversely, with regards to the opinions of the Commission on the state of preparedness of the candidate states, the Council "accepted the methodological approaches followed by the Commission". ${ }^{100}$ The Council also echoed the Commission's assertion that the satisfactory compliance with the political criteria was a pre-condition for the opening of accession negotiations. Lastly, the council agreed that accession negotiations should be opened only with Hungary, Poland, Estonia, the Czech Republic and Slovenia. $^{101}$

The subsequent Luxemburg European Council, at its December of 1997 meeting discussed the report provided by the Council. ${ }^{102}$ The outcome of this discussion was the full agreement with the particulars of the report provided by the Council. As such, the

\footnotetext{
98 Council, Presidency report on Agenda 2000, (December 1997), Part I: 8.

${ }^{99}$ Ibid, 8.

${ }^{100}$ Ibid, 2.

101 Ibid.

102 European Council, Presidency Conclusions, Euroepan Council (Luxemburg: European Council, December 1997).
} 
member states were indeed to play an important, and de facto, veto-like role in the creation of the individual Accession Partnerships. ${ }^{103}$ Lastly, the European Council called for the opening of accession negotiations with the candidate states that had been proposed by the Council's communication. Consequently, the following paragraphs discuss the empirical evaluation of this phase of the enlargement process.

The empirical analysis of the role of the Commission in creating Agenda 2000 is made more complicated than the previous phases of the pre-negotiation stage due to the inclusion of three major components. This is notwithstanding the fact that the present analysis does not include a discussion of the first major component of the Agenda 2000 report. Consequently, the following analysis fuses the discussion of the enhanced preaccession strategy with the discussion of the Commissions' opinions on the applications for membership by the candidate states.

Regarding the first variable, there is no evidence suggesting that there were high commitment related transaction costs associated with either SPAR or the Commission's opinions. Conversely, both components of Agenda 2000 under examination have displayed the characteristics of a complex policy environment, thus we can conclude that there were high information related transaction costs. The third component of this variable - the negotiation related costs - presents a curious case with respect to the SPAR portion of the communication. This is because in developing the enhanced pre-accession strategy the Commission was under the impression that the negotiation of the Accession Partnerships would inherently have high transaction costs. As a result, the supranational institution proposed that it should be the one responsible for the conduct of these negotiations. However, the member states were not of the same opinion and assumed the ${ }^{103}$ Ibid. 
responsibility to negotiate these agreements themselves. Conversely, unlike SPAR, the Commissions' opinions did not display evidence of the existence of any negotiation costs. Consequently, the convoluted and limited nature of the evidence suggests that this variable does not illuminate the role of the Commission very well.

Unlike the previous variable, the second one - related to the informational asymmetry between the Commission and the member states - is better evidenced within this phase. This is due to the fact that the member states only provided the general direction for the report, which illustrates that the informational asymmetry bias was indeed in favor of the supranational institution. ${ }^{104}$ This is not surprising, however, given the fact that it was the Commission that created the initial pre-accession strategy. Similarly, the opinions on the application for membership required the generation and processing of vast amount of information from the candidate states, which only the Commission was in a position to accomplish individually for each of the twelve candidate states.

While the evidence regarding the second variable is quite clear, the third variable does not welcome this level of analytical clarity. This is because neither SPAR, nor the Commission's opinions fit neatly into the distinction of competencies between the member states and the Commission. In fact, both areas display components from the competencies of each side. The opinions examine the preparedness of the candidate states in every Union related policy area, and similarly, SPAR establishes priorities for each of the sectors covered within the acquis. Therefore, the evidence presented above does not illuminate this variable very clearly.

The mode of delegation was briefly discussed under the analysis of the second

\footnotetext{
${ }^{104}$ See the discussion of the Madrid European Council conclusions.
} 
variable. In that discussion I suggested that the member states has delegated the duty to prepare the proposals under the Agenda 2000 on the basis of some very general guidelines. This in turn, illustrates that this delegation falls under the definition of the fiduciary mode. Overall, the fact that the Council, and consequently the European Council, approved the findings and proposals of Agenda 2000 - with the notable exception of the proposed negotiation of the Accession Partnerships solely by the Commission - suggests that the role of the supranational institution was definitely that of a bureaucratic entrepreneur.

Section V-From Luxemburg to Helsinki:

While some of the candidate states commenced the accession negotiations following the conclusions of the Luxemburg European Council in 1997, Bulgaria and Romania were considered not adequately prepared to proceed to this stage. Therefore, this section traces the developments that lead to the beginning of the negotiations with these two candidate states following the Helsinki European Council in December of 1999.

These developments find their beginning at the Cardiff European Council in June of 1998, where the heads of state "welcomed the Commission's confirmation that it will submit at the end of 1998 its first regular reports on the candidates progress towards accession". ${ }^{105}$ In the meantime, on March $16^{\text {th }}$ of 1998 the Council had adopted the official regulation, which under Article 2 stated that "following a proposal by the Commission, the Council shall decide by qualified majority on the principles, priorities, intermediate objectives and conditions contained in the individual Accession

${ }^{105}$ European Council, Presidency Conclusions, European Council (Cardiff: European Council, June 1998), 22. 
Partnerships, as they will be submitted to each applicant State, as well as on subsequent significant adjustments applicable to them" ${ }^{106}$ In relation to this decision - initially established by the Council as a response to the proposals of Agenda 2000 - the Commission prepared a proposal for a Council decision on the principles, priorities, intermediate objectives, and conditions contained in the Accession Partnerships with Bulgaria and Romania. ${ }^{107}$

These proposals were then reviewed and amended by the European Parliament and ultimately adopted by the Council on March $30^{\text {th }}$ of 1998 . Unfortunately however, these Commission proposals are not available for review and therefore cannot be juxtaposed with the final Council decisions for empirical evaluation. This is all the more problematic, due to the fact that these decisions established, in effect, the first Accession Partnerships with the two countries. Moreover, these Partnerships were updated yearly until the time of the conclusion of the accession negotiations - to reflect the progress, or the regress, of the candidate states. Similarly to the first such Partnerships, the original proposals by the Commission are not available for any of the following Council decisions. This in turn renders the analysis of the Accession Partnerships impossible. Consequently, the attention in this section will shift to the other components of the journey to the 1999 Helsinki European Council.

Following the conclusion of the Accession Partnerships in 1998, the Commission prepared the reports on the progress of the candidate states towards accession on

106 Council, On assistance to the applicant States in the framework of the pre-accession strategy, and in particular on the establishment of Accession Partnerships, Council of Ministers (Brussels: Council of Ministers, March 1998), 2.

107 Commission, Proposal for a Council Decision on the principles, priorities, intermediate objectives and conditions contained in the Accession Partnership with Bulgaria., European Commission (Brussels: European Commission, February 1998); Commission, Proposal for a Council Decision on the principles, priorities, intermediate objectives and conditions contained in the Accession Partnership with Romania., European Commission (Brussels: European Commission, February 1998). 
November $4^{\text {th }}$ of 1998 . The progress reports occurred simultaneously with the accession process and were de-facto snapshots of the process of the negotiations. ${ }^{108}$ These reports were based on information provided by each candidate state and verified by the Commission, where the supranational institution evaluated the progress of the candidate states on the basis of the criteria defined by the 1993 Copenhagen as well as the 1995 Madrid European Councils. ${ }^{109}$ As a result, the reports were divided into four sections reflecting the requirements for membership: the political criteria, the economic criteria, the ability to assume the obligations of membership, and the administrative capacity to apply the acquis.

Therefore, Nikolova has identified them as influential, particularly because a) they were "recognized ... as a fair overall evaluation of domestic reforms", b) they allowed the Commission to identify key areas for further improvement, and c) they created pressure under which officials carried out reforms in order to have the "evidence of progress" presented at the subsequent report. ${ }^{110}$ Once published, the monitoring reports served as a useful tool for the member states as a snapshot of the on-the-ground situation of each candidate states'. ${ }^{111}$ In addition, these reports were used by the Commission as a basis for its recommendations presented in the other communications to the member states.

Consequently, on the basis of these reports the Commission presented to the Council a composite paper outlining the findings of the progress reports and its

108 Interviewee from a Member State Permenent Representation, The Role of the Commission in Enlargement, Martin Manolov (8 May 2009).

${ }^{109}$ Serpe, Interview at the Romanian Permanent Representation, (4 May 2009).

110 Pavlina Nikolova, "Negotiating for EU Membership? - The Case of Bulgaria and Romania," Croatian Yearbook of European Law and Policy 2.1 (2006): 393-412, 401.

111 Interview at the European Commission, The Role of the Commission in the Accession of Bulgaria and Romania, Martin Manolov (15 May 2009). 
subsequent recommendations. ${ }^{112}$ The most important component of the 1998 composite paper recommendations was not to commence accession negotiations with the remainder of the candidate states due to the fact that these countries had not made sufficient progress that would allow for this process to begin. ${ }^{113}$ In relation to Bulgaria and Romania in particular the Commission concluded that "Bulgaria has made considerable progress in macroeconomic stabilisation (sic) and the reforms which are being implemented, although at an early stage, are helping to improve its international competitiveness. Romania has not made further progress since the Opinion and its economic situation gives cause for concern. Sustained efforts are needed, with the support of the EU and the international community, to accelerate reforms and put Romania back on track". 114

In response the General Affairs Council "welcomed the Commission's first regular reports" and restated its agreement regarding the methods employed by the institution in its analysis of the candidate states. ${ }^{15}$ With respect to the progress reports the Council reiterated the major areas where progress by the candidate states was required - such as: the treatment of minorities, the "application of all elements of the single market acquis", and the need for an accelerated legislative approximation. ${ }^{116}$ Lastly, and most importantly, the Council concluded - reflecting the Commission's recommendation - that "at this stage the Council did not make any recommendation to

\footnotetext{
112 Commission, COMPOSITE PAPER Reports on progress towards accession by each of the candidate countries, European Commission (Brussels: European Commisssion, November 1998).

113 Ibid.

${ }^{114}$ Ibid, 28.

115 Council, 2148th GENERAL AFFAIRS - COUNCIL CONCLUSIONS, Council of Ministers (Brussels: Council of Ministers, December 1998), 4.

${ }^{116}$ Ibid, 4.
} 
the European Council to extend accession negotiations". ${ }^{117}$ Consequently, the European Council confirmed the conclusions, of the General Affairs Council, at its meeting in December of 1998. At this meeting the heads of state also urged the Commission to "present its further progress reports in view of the Helsinki European Council" in December of $1999 .{ }^{118}$

The next installment of the progress reports came dutifully on October $13^{\text {th }} 1999$. Similarly to the previous reports, the Commission prepared a Composite Paper with the general findings and appropriate recommendations. ${ }^{119}$ While the findings of this report suggested that the candidate states still have much work ahead in order to be fully prepared for the assumption of the obligations of the acquis communautaire, the Commission also proposed that sufficient progress had been made by the candidate states for the Union to commence accession negotiations. ${ }^{120}$ With respect to Bulgaria and Romania however, this recommendation was conditional on: "decision by the Bulgarian authorities, before the end of 1999, on acceptable closure dates for Units 1-4 in Kozloduy nuclear power plant, and upon a confirmation of the significant progress accomplished in the economic reform process" and "confirmation of effective action announced by the Romanian authorities to provide adequate budgetary resources and to implement structural reform of child care institutions before the end of 1999; it is also conditional upon a further assessment of the economic situation before negotiations are formally opened, in the expectation that appropriate measures will have been taken to address the

\footnotetext{
${ }^{117}$ Ibid, 5 .

118 European Council, Presidency Conclusions, Euroean Council (Vienna: Euroepan Council, December 1998), 5.

119 Commission, COMPOSITE PAPER Reports on progress towards accession by each of the candidate countries, European Commission (Brussels: European Commission, October 1999).

${ }^{120}$ Ibid.
} 
macro-economic situation". 121

Consequently, it was on the basis of this recommendation that the Helsinki European Council, in December of 1999, decided to commence accession negotiations with Romania, Slovakia, Latvia, Lithuania, Bulgaria and Malta. In this decision the European Council stated that the beginning of these negotiations would "lend a positive contribution to security and stability on the European Continent". ${ }^{22}$ As a result, this decision, marked the conclusion of the pre-negotiation stage of the enlargement process.

The limitations posed by the inaccessibility of the Commission's proposals for the Accession Partnerships frustrate any attempt to carry out a conclusive analytical exercise of any quality. In addition, the second component of this phase - the Commission's progress reports - is, in methodology and function, quantitatively a mirror image of the initial opinions presented by the institution in its Agenda 2000 report. As a consequence, the empirical analysis of these documents would invariably mimic the conclusions presented in the previous section.

As a matter of fact, the entire process from the conclusions of the 1997 Luxemburg European Council to the conclusions of the 1999 Helsinki European Council differs, from the discussion presented within the analysis of the Agenda 2000 report, only in the existence of the Accession Partnerships. This is of course not to suggest that little else worthy of discussion has occurred during this time-period, rather I suggest that with respect to the accession progress of Bulgaria and Romania alone, this phase of the prenegotiation stage is rather devoid analytical potential. This is mainly due to the fact that, as I have suggested above, the process of creating the Accession Partnership does not

\footnotetext{
${ }^{121}$ Ibid, 39.

${ }_{122}$ Euroepan Council, Presidency Conclusions, Euroepan Council (Helsinki: European Council, December 1999), 2.
} 
allow for empirical evaluation.

Consequently, the only notable event that remains was the fact that the European Council unequivocally followed the recommendations of the Commission for beginning the accession negotiations. This however, is not surprising given the approval awarded by the member states to the Commission's initial candidate state evaluations - the Commission's opinions. As a result, this phase does not allow one to draw specific conclusions regarding the role of the Commission. Nevertheless, this phase informs the general observation concluding that the Commission was heavily involved, in preparing information and developing proposals for the member states, throughout the entire duration of the pre-negotiation stage of the enlargement process.

Section VI-Overall Evaluation:

The empirical analysis of the role of the European Commission throughout the pre-negotiation stage of the enlargement process was based on the three variables presented in the first chapter of this work. These variables included: the costs for identifying and negotiating common strategies, the informational asymmetry, and distribution of competencies between the Commission and the member states. The evaluation of these variables was conducted on the basis of the five phases of the prenegotiation process. $^{123}$

Overall the outcome has illustrated that the institution has been delegated responsibilities under the fiduciary mode of delegation at every instance. Similarly, most of the phases of the pre-negotiation stage were characterized with the existence of a high informational asymmetry in favor of the Commission; that is with the notable exception

\footnotetext{
${ }^{123}$ It is important to reiterate that the last phase of the pre-negotiation process - the path from Luxemburg to Helsinki - did not allow for conclusive empirical evaluation to be conducted, as such, this phase is not discussed in these concluding remarks.
} 
of the development of the initial pre-accession strategy. Conversely, it was not always possible to determine whether the distribution of competencies favored the Commission or the member states. Lastly, the transaction costs related to the development of common strategies were oscillating between moderate and high levels. Therefore, the overall conclusion is that the Commission was able to, at all phases of the pre-negotiation stage, to generate optimal strategies for the accomplishment of the first order preferences of the member states. Consequently, the evidence has illustrated that the overall function of the Commission at this stage of the enlargement process was that of a bureaucratic entrepreneur. 


\section{Chapter III: The Negotiation Stage}

In the previous Chapter of this paper I discussed the pre-negotiation stage of the enlargement process. Conversely, the goal of this chapter is to examine the function of the Commission within the various phases of the negotiation stage of the accession of Bulgaria and Romania to the European Union. In order to achieve this goal I have divided this chapter into five sections, which identify the main phases of the negotiations. These were: the creation of the road maps, the preparation of the Draft Common Positions, the debates within the Council working group on enlargement, the substantial negotiation between the candidate states and the Union, and finally this chapter - similarly to the previous one - concludes with a overall evaluation of the role of the Commission.

This division of the negotiation stage reflects the complex decision-making structure inherent in the negotiation process, where even practitioners recognize this as "very complicated". ${ }^{1}$ This complexity arises from the fact that simultaneous rather then consecutive movements characterize this stage of the enlargement process, which is most clearly reflected in the fact that not all chapters are opened for substantial negotiations simultaneously. Similarly, the sequence of opening and closing the various chapters did not occur at regular intervals of time. Rather, it varied depending on the level of complexity inherent in each chapter and the level of preparedness by the candidate states. Consequently, the member states would be carrying on substantive negotiations on some chapters with the candidate states while at the same time the Council working group would be debating the final incarnation of the DCPs for other parts of the acquis.

\footnotetext{
${ }^{1}$ Ion Serpe, Interview at the Romanian Permanent Representation, Martin Maanolov (4 May 2009).
} 
Nevertheless, there is a clear hierarchy of events. This hierarchy is the result of the complex decision-making required for the opening and closing of the substantial negotiations with the candidate states. Consequently, the organization of the various sections of this chapter reflects this hierarchy.

Section I-The Road Maps for Negotiation:

Following the Helsinki European Council meeting in December of 1999, substantive negotiations began with Bulgaria, Latvia, Lithuania, Malta, Romania and Slovakia. $^{2}$ Consequently, at its next meeting at Feira in June of 2000 the European Council commended the candidate states on their progress to date. More importantly however, the heads of state reiterated the importance of monitoring the progress of the applicants and to this end invited the Commission to report its findings to the Council of Ministers. ${ }^{3}$

This invitation most notably referred to the yearly monitoring reports that the Commission prepared for each candidate states. Despite this however, the Commission perceived this invitation, by the Feira European Council, to be a carte blanche for the more thorough evaluation of the negotiation process and consequently, on November $8^{\text {th }}$ of 2000, it prepared a report titled: "Enlargement Strategy Paper - a Report on Progress Towards Accession by Each of the Candidate Countries". ${ }^{4}$ This report was prepared on the basis of these yearly monitoring reports, as such, it was a composite of many components, most of which were a reiteration of already agreed upon proposals, such as

\footnotetext{
${ }^{2}$ The term "substantive negotiations" refers to the discussion between the candidate states and the Union upon the opening of each of the chapters of the acquis.

3 European Council, Presidency Conclusions, European Council (SANTA MARIA DA FEIRA: European Council, June 2000).

${ }^{4}$ Commission, Enlargement Strategy Paper Report on progress towards accession by each of the candidate countries, European Commission (Brussels: European Commission, November 8th 2000).
} 
the enhanced pre-accession strategy, a description of the overall context of the enlargement and a summary of the monitoring reports. ${ }^{5}$ The report however also included a discussion of the accession negotiations, it was within this component that the Commission proposed the adoption of a "road map for the negotiations". 6

This road map took "the form of a sequenced approach to the chapters in the negotiations". ${ }^{7}$ According to the Commission the road map "would permit the progress on chapters that remain open". ${ }^{8}$ The institution also acknowledged that the realizations of the goals proposed in the road map depended on the progress made by the candidate states and as such, "the schedule may not be realized for all candidates on all chapters in the given time periods". ${ }^{9}$ Nevertheless, the road map established the priorities that were to be tackled by the negotiations until the first half of 2002 . This meant in effect that the candidate states would submit their position papers in accordance to this schedule, and in turn the Commission would prepare the Draft Common Positions which the Council would approve, thus allowing for substantial negotiations on those chapters to be commenced. ${ }^{10}$ Therefore, the road map effectively proposed that the EU should complete its Common Positions during the ensuing three periods of six months. ${ }^{11}$

The General Affairs Council reviewed the proposed road map on November of 2000. At this meeting the Council, while welcoming the other components of the report, merely stated that the road map "was purely indicative, and the Commission would have

\footnotetext{
${ }^{5}$ Ibid; The monitoring reports will be discussed in more detail in Section $\mathrm{V}$ of the previous chapter and as such further discussion is not necessary here, see page 67.

${ }^{6}$ Ibid, 27.

${ }^{7}$ Ibid, 27.

${ }^{8}$ Ibid, 27.

${ }^{9} \mathrm{Ibid}, 28$.

${ }^{10}$ Ibid.

11 Graham Avery, "The Enlargement Negotiations," Fraser Cameron, The Future of Europe - Integration and Enlargement (Routledge, 2004) 35-63.
} 
to adapt it to the developments in the situation and to the progress made". ${ }^{12}$ This effectively reiterated the Commissions' acknowledgement of the need for versatility of the road map, but as such, the Council did not whole-heartedly approve the proposed road map. Nevertheless, the Council did forward this proposal for further review by the Committee of Permanent Representatives (COREPER). ${ }^{13}$

As a result of this discussion, it appears that the Council had experienced a change of heart. For, at its following meeting on December $4^{\text {th }}$ of 2000 , the body of member state representatives stated that it "welcomes the road map which has been proposed for the next 18 months by the Commission, whose ambition it shares and by which it will be inspired in the conduct of the negotiations [emphasis added]". ${ }^{14}$ The Council also identified the road map as a reflection of the Union's commitments towards the candidate states. ${ }^{15}$ This represented a shift in the opinion of the Council, but also a full endorsement for the Commission's proposal. Nevertheless, the Council reiterated that the road map needed to be "fine tuned to the progress made by each candidate...". 16

Consequently, the Nice European Council at its December of 2000 meeting "endorsed the General Affairs Council conclusions of 4 December 2000 concerning the strategy proposed by the Commission". ${ }^{17}$ More specifically however, the European Council restated that the road map must differentiate between the candidate states on the

12 Council, 2308th Generl Affairs - Council Conclusions, Council of Ministers (Brussels: Council of Ministers, November 20th 2000).

${ }^{13}$ Ibid.

14 Council, 2316th General Affairs - Council Conclusions, Council of Ministers (Brussels: Council of Ministers, December 4th 2000), 5.

${ }^{15}$ Ibid.

${ }^{16} \mathrm{Ibid}, 5$.

17 European Council, Presidency Conclusions, European Council (Nice: European Council, December 2000), 2. 
basis of the progress of their reforms. ${ }^{18}$ Nonetheless, the message was clear: the road map was approved by the member states in its entirety.

As a result, with the stamp of highest endorsement, the negotiations progressed within the framework of the Commissions' proposed and consequently, self implemented, road map. The Council at its April $9^{\text {th }}$ of 2001 meeting repeated its commitment to follow the proposed road map and called on the Commission to prepare the DCPs necessary "in order to enable the Union to define its position as soon as possible in accordance with the road map" ${ }^{19}$ Consequently, the European Council at Goteborg in June of 2001 praised the road map as "an ambitious and realistic framework for the negotiations". ${ }^{20}$ And thus, by July of 2001 the Council acknowledged the contributions of the Commission and noted that the "objectives set out in the road map for the first half of 2001 have been met" ${ }^{21}$

These included the chapters regarding the free movement of goods, services, persons and capital; company law; culture and audio-visual policy; social policy and employment; environment; and external relations. ${ }^{22}$ In its following progress report at the end of 2001 however the Commission identified that, while negotiation with Bulgaria were opened on all but three of these chapters - the free movement of persons, social policy and employment, and the environment - Romania had only opened negotiations

\footnotetext{
${ }^{18}$ Ibid.

19 Council, 2342nd General Affairs - Council Conclusions, Council of Ministers (Brussels: Council of Ministers, April 9th 2001), 6.

20 European Council, Presidency Conclusions, European Council (Goteborg: European Council, June $2001), 3$.

${ }^{21}$ Council, 2356th General Affairs - Council Conclusions, European Council (Brussels: European Council, July 11 th 2001), 5 .

${ }^{22}$ Commission, Enlargement Strategy Paper, (Brussels: European Commission, November 8th 2000).
} 
with four of the ten chapters - the free movement of capital, social policy and employment, external relations, and company law. ${ }^{23}$

As a result, by the end of 2001, it was clear that not all candidate states would be able to join the Union simultaneously. As a result the Commission proposed to "set out an updated road map", in its 2002 enlargement strategy paper, for those countries that were lagging behind. ${ }^{24}$ The Council at its December 10th meeting welcomed this proposal. ${ }^{25}$ And the European Council at its Laeken meeting in December of 2001 stated that "there must be a precise framework with a timetable and an appropriate road map, the objective being to open negotiations with those countries [the ones that were lagging behind in their reforms] on all chapters in $2002 "{ }^{26}$ This provided a clearer formulation for what was required from the Commission in its preparation of the road maps for Bulgaria and Romania.

As proposed, in November of 2002 the Commission presented a report detailing the road maps for the two candidate states. These road maps were intended to outline the progress that needed to be achieved by the two countries in order for them to become ready for accession, thus the road maps covered "the period up to accession". ${ }^{27}$ Moreover, the road maps detailed the short - and medium - term objectives for Bulgaria

${ }^{23}$ Commission, Making a success of enlargement Strategy Paper and Report of the European Commission on the progress towards accession by each of the candidate countries, European Commission (Brussels: European Commission, November 13th 2001).

${ }^{24} \mathrm{Ibid}, 28$.

${ }^{25}$ Council, 2397th General Affairs - Council Conclusions, Council of Ministers (Brussels: Council of Ministers, December 10th 2001).

${ }^{26}$ European Council, Presidency Conclusions, European Council (Brussels: European Council, December 2001), 4 .

27 Commission, COMMUNICATION FROM THE COMMISSION TO THE COUNCIL AND THE EUROPEAN PARLIAMENT Roadmaps for Bulgaria and Romania, European Commission (Brussels: European Commission, November 13th 2002), 2. 
and Romania in the areas of administrative and judicial capacity, economic reforms, and the 29 chapters of the acquis communautaire. ${ }^{28}$

Consequently, the Council at its meeting in November $21^{\text {st }}$ of 2002 "took note" of the proposed road maps. ${ }^{29}$ These were in turn, wholly endorsed by the Copenhagen European Council at its meeting in December of 2002. ${ }^{30}$ The European Council stated that the road maps "provide Bulgaria and Romania with clearly identified objectives and give each country the possibility of setting the pace of its accession process". ${ }^{31}$ In addition, the heads of state urged the candidate states to "step up their preparation" in the areas that were highlighted by the Commission's proposal. ${ }^{32}$ With this renewed impetus the candidate states were to deliver their position papers and the Commission was left to prepare the corresponding DCPs for the approval of the member states.

Turning to the empirical analysis, the broad mandate that the 2000 Feira European Council awarded to the Commission is an indication of particularly high information related transaction costs. This is also confirmed by the fact that the proposal of the Commission to prepare additional and separate road maps for Bulgaria and Romania was easily accepted by the member states. These high transaction costs were the result of the complex nature of the policy-environment, which required the comprehensive understanding of all accession criteria and their application to each candidate state. ${ }^{33}$

\footnotetext{
${ }^{28}$ Ibid.

29 Council, 2463rd General Affairs - Council Conclusions, Council of Ministers (Brussles: Council of Ministers, November 21st 2002), 8.

30 European Council, Presidency Conclusions, European Council (Copenhagen: European Council, December 2002).

${ }^{31}$ Ibid, 5 .

${ }^{32}$ Ibid, 5.

${ }^{33}$ This is referring to both of the criteria developed by the 1993 Copenhagen European Council as well as the 1995 Madrid European Council.
} 
Similarly, the fact that the Commission was the institution that implemented the road maps intimates the existence of high negotiation related transaction costs. These in turn, were resultant of the infrequent contact between the member states and the candidate states and the varying degree of thoroughness that characterized the instance of such contact. Moreover, it was the Commission that - as a result of its monitoring functions - was most thoroughly aware of the progress of the candidate states; and thus, it was the Commission that best knew where further improvements were required and where substantial negotiations could be commenced.

In contrast, the third component of the first variable is more ambiguous. The very fact that the Commission created the road map suggests that the institution perceived there to be high commitment related costs inherent in the negotiation stage itself. This is made more explicit by the assertion of the Commission that the road map was a way to ensure that all parties privy to the process would "commit themselves to a realistic timetable". ${ }^{34}$ Conversely, the fact that, at their initial examination of the road map the member states did not approve this proposal, points to the understanding that the Council disagreed with this supposition. The analysis is additionally complicated as a result of the subsequent approval of the road map by the Council following the discussion of this proposal at the COREPER level. Furthermore, because the discussion between the committee of permanent representatives is classified, and thus unavailable, one can only speculate that the member states altered their perception of the level of commitment related transaction costs. Despite this ambiguity however, the evidence presented in the

\footnotetext{
34 Commission, "EUROPA," 2001, Enlargement of the European Union - An historic opportunity, European Commission, 02 April 2009, 22.
} 
discussion of the road map phase has illustrated that there were indeed high costs associated with the identification and negotiation of common strategies.

The second variable examines the level of informational asymmetry between the Commission and the member states. In this respect, there is conclusive evidence that suggests that an information asymmetry did exist and that it was in favor of the Commission. This conclusion is best illuminated by the fact that the member states, a) did not attempt to alter the proposed framework of the road maps, and b) relied entirely on the judgment of the institution to prepare the necessary DCPs in accordance to the timeframe proposed within the road map. Lastly, the third variable seeks to determine the distribution of competencies between the supranational institution and the member states. Here, the road map phase presents an anomaly. This is because the Commission's proposals, under the road map framework covered not only areas under its own competencies, but also areas under the competencies of the member states.

Consequently, the overall evaluation suggests that, within this phase of the negotiation stage, the Commission was delegated duties under the fiduciary mode, indeed the evidence presented in the above discussion, supports this. Therefore, the Commission was able to influence the second order preferences of the member states by developing acceptable strategies for the implementation of their first order preferences, which in this case were the successful conduct of the accession negotiation. As a result, it can be clearly stated that at this phase the Commission acted in the capacity of a bureaucratic entrepreneur. 
Section II-The Draft Common Position:

The substantive negotiations were carried out through the exchange of written documents. This exchange commenced with the presentation of the so-called position papers by the candidate states, which were prepared by their respective negotiating teams. ${ }^{35}$ These position papers outlined the candidates' requests for transition periods regarding the application of the acquis on each of its individual chapters. ${ }^{36}$

Consequently, the position papers were then reviewed by the Commission, following which the institution drafted negotiating positions called the Draft Common Positions. ${ }^{37}$ Just as the candidate states would prepare a separate position paper for each chapter of the negotiations, the Commission would prepare a separate DCP as a response. Avery has suggested that this "bilateral" nature of the negotiation process was desirable for both the EU and the candidate states. ${ }^{38}$ Nevertheless, this was not entirely practicable - mostly because a "concession to one applicant was likely to be claimed by the others ${ }^{, 39}$ Consequently the Commission would prepare negotiating positions, which were "often similar or even identical" 40

While the DCPs themselves cannot be evaluated, one can scan through the final arrangements of the negotiations and find those riddled with examples where more than one candidate states has received the exact same transition arrangements. One example includes the chapter on transport, where most of the candidate states received transition periods with respect to the access of non-resident trucks to the national transport

\footnotetext{
35 Alan Mayhew, "Enlargement of the European Union: An Analysis of the Negotiations with the Central and Eastern European Candidate Countries," SEI Working Paper No.39 December 2000: 2-71.

${ }^{36}$ Leonard Orban, Interview at the European Commission, Martin Manolov (4 May 2009).

${ }^{37}$ Ibid.

${ }_{30}^{38}$ Avery, "The Enlargement Negotiations" (2004).

${ }^{39}$ Ibid, 39.

${ }^{40} \mathrm{Ibid}, 39$.
} 
market. ${ }^{4}$ Another, such example is located within the chapter on agriculture, where most candidate states received transition periods with respect to the veterinary and phytosanitary aspects of the acquis. ${ }^{42}$ And lastly, the most prominent example comes from the chapter on the free movement of capital where the candidate states received long transition periods with regards to the acquisition of land by foreign nationals. ${ }^{43}$

The DCPs included all of the assessments of the missions carried out by the Commission, this also incorporated information received by member state experts, which were employed on the ground at the candidate states. ${ }^{44}$ The main function of the DCPs was to evaluate the transition periods requested by the candidate states. ${ }^{45}$ These requests were in turn classified by the Commission as "acceptable, negotiable and nonacceptable" ${ }^{46}$ Consequently, these were either accepted, rejected or modified by the member states. ${ }^{47}$ Nikolova has described the process of creating each DCP as coordinated by DG Enlargement with the relevant sectoral DGs providing the technical expertise. ${ }^{48}$

The preparation of the DCP was thus a highly complex exercise where the various DGs would contribute their technical expertise in the evaluation of the requests of the candidate states. Consequently, what was included or not included in a particular DCP was of great importance to the direction of the negotiations. As a result of this, the Commission was one step ahead of the national governments when it came to questions

41 Commission, Progress in the negotiations, European Commission, 23 August 2010 $<\mathrm{http} / /$ ec.europa.eu/enlargement/archives/enlargement_process/future_prospects/negotiations/eu10_bulgar ia romania/chapters/index_en.htm>.

${ }^{42}$ Ibid.

${ }^{43}$ Ibid.

${ }^{44}$ Orban, Interview at the European Commission, (4 May 2009).

45 Pavlina Nikolova, "Negotiating for EU Membership? - The Case of Bulgaria and Romania." Croatian Yearbook of European Law and Policy 2.1 (2006): 393-412.

${ }^{46} \mathrm{Ibid}, 404$.

${ }^{47}$ Serpe, Interview at the Romanian Permanent Representation, (4 May 2009).

${ }^{48}$ Nikolova, Negotiating for EU Membership? (2006). 
regarding the DCP, particularly compared to small and medium member states. ${ }^{49}$ This was exacerbated by the fact that the Commission had full autonomy in creating the DCPs.

In turn the member states would attempt to steer the Commission in the creation of the DCP, however if the Commission perceived the member state's suggestions were misplaced it would not follow their advice. ${ }^{50}$ If however, the institution viewed the proposals as grounded in the acquis it would "take them on board". 51 Nevertheless, this process of influencing the text of the DCP was painstaking, and as such small or medium member states would not attempt it on their own, rather they would try and garnish the support of other member states and most preferably that of the big member states. ${ }^{52}$ One interviewee, has suggested that it would be an exercise in futility to influence the Commission at the drafting stage unless they have been able to generate the support of at least two of the three big member states. ${ }^{53}$

In order for the member states to be better prepared in their attempts to influence the initial text of the DCP they would inquire from the Commission the progress of individual candidate states on particular chapters. ${ }^{54}$ Consequently, the drafting of the DCP was an exercise in generating "composite solutions that usually become the basis for joint positions of the existing member states and then for an agreement between them

49 Interviewee from a Member State Permenent Representation, The Role of the Commission in Enlargement, Martin Manolov (8 May 2009).

${ }^{50}$ Ibid.

51 Ibid.

52 Ibid.

${ }^{53}$ Ibid.

${ }^{54}$ Yotova, Interview at the Bulgarian Permanent Representation, (4 May 2009). 
and the candidates". 55 Therefore, the Commission would attempt to draft a DCP that could most easily be agreed upon by most member states in the working group. ${ }^{56}$

Once the Commission had completed the drafting of the initial DCP it would present the document to the member states' representatives in the Council working group for enlargement. ${ }^{57}$ Because the DCPs were centered on narrowly specific issues, they were perceived as priority areas only by some governments but not all simultaneously. ${ }^{58}$ As a result not all member states would present their opinions on every DCP. Similarly, different member states would suggest the inclusion of different aspects; such as they would best illuminate the candidate states' preparations and reforms of the sectors most important to the given member state. ${ }^{59}$ Some member states would be more concerned with issues related to the energy chapters, such as Germany and Austria. Others would be more concerned with agriculture such as France for example.

Finally, the candidate states were only presented with the final, agreed upon, DCP, which was then called the Common Position of the European Union. ${ }^{60}$ The decision-making process, the outcome of which is the Common Position of the EU, between the member states was rather complicated and timely; therefore the next section is dedicated to providing a detailed description of the negotiations that occurred within the Council working group on enlargement. This marks the conclusion of the discussion of this phase of the process, consequently in the following few paragraphs I will present its empirical evaluation.

55 Desmond Dinan, "The Commission and Enlargement," John Redmond and Glenda G. Rosenthal, The Expanding European Union - Past, Present, Future (Lynne Rienner Publishers, 1998) 17-41, 21.

${ }_{56}$ Yotova, Interview at the Bulgarian Permanent Representation, (4 May 2009).

${ }^{57}$ The following section discusses the function of this working groups in further detail.

58 Ibid.

${ }^{59}$ Babicz, Interview at the Permanent Representation of Slovakia, (5 May 2009).

${ }^{60}$ Yotova, Interview at the Bulgarian Permanent Representation, (4 May 2009). 
The creation of the DCP was associated with the profound understanding of the particular circumstance of each candidate state vis-à-vis each chapter of the acquis. As such, this reflected a particularly complex policy environment, which in turn suggests that there were high information related transactions costs involved in preparing the DCP. Conversely, the fact that the negotiation of the DCPs occurred following its presentation to the working group suggests that, throughout the creation of the DCPs there were not significant negotiation related transaction costs. Regarding the commitment related costs; such were not a subject of analysis because the initial DCP as such did not establish any commitments - which were ascertained only following the agreement on the final EU Common Position. Similarly, as a result of the significant familiarity with the particular circumstances of each of the candidate states that was required in order to prepare the DCP, the informational asymmetry was in favor of the Commission. Unfortunately due to the fact that the DCPs are classified documents one cannot determine whether the member states were able to influence the Commission's preparation of the DCPs in the areas that the member states carry more competencies.

This analysis does not however, definitively suggest that the Commission was able to influence the second order preferences of the member states, despite the fact that the Commission was delegated authority in the fiduciary mode, which is evidenced by the autonomous preparation of the DCP. This is due to the fact that following the presentation of each DCP the member states would discuss its contents within the Council working group. Only following this discussion did the DCP become the official EU Common Position, on which the substantial negotiations were conducted. Therefore, without the analysis of the processes in play within the working group one cannot 
determine the level of influence of the Commission in this phase of the process. The next section is dedicated to this evaluation. Nevertheless, it is important to note that this current phase of the negotiation stage is characterized by the relatively high autonomy of the Commission vis-à-vis the member states.

\section{Section III-The Working Group:}

Most of the work preparing the Common Position of the EU was done in the Council working group for enlargement. ${ }^{61}$ One practitioner has described the atmosphere of the working groups in the following manner "these are diplomats we are dealing with and tensions always play out in a very civilized manner but [they are there] and those who have ears to hear with can interpret what is said and can see what are the underlying policy differences". ${ }^{2}$ This illustrates that the negotiations between the member states were "at least as difficult and complex as those between the Union and the candidate countries". 63

This group met on a weekly basis in order to discuss the proposed DCPs. ${ }^{64}$ These discussions were characterized by the fact that each country had varying national priorities regarding each chapter of the negotiations, and it is within the working group that the member states could forward their specific questions and points of interest. ${ }^{65}$ Therefore, following the drafting of the DCP, the role of the Commission was weakened by the fact that it was not in a possession of a vote at the Council working group. Nevertheless, the substantial fact of the matter was that the member states tried to

\footnotetext{
${ }^{61}$ Mayhew, SEI Working Paper No.39, (December 2000).

${ }^{62}$ Interviewee, The Role of the Commission in Enlargement, (8 May 2009).

${ }^{63}$ Mayhew, SEI Working Paper No.39, (December 2000), 17.

${ }_{65}^{64}$ Orban, Interview at the European Commission, (4 May 2009).

${ }^{65}$ Babicz, Interview at the Permanent Representation of Slovakia, (5 May 2009).
} 
cooperate with the Commission. ${ }^{66}$ Consequently, the member state representatives would often contact the Commission prior to preparing their proposed amendments to the DCP. $^{67}$

As the previous section identified the Commission as the autonomous drafter of the initial DCPs, it is thus not surprising that the supranational institution was the one that the member states most frequently looked to in order to prepare their own positions vis-àvis the DCP. The Commission however, was not the only source of such information. Most of the member states had established their own networks for generating policy relevant information. This section seeks to determine how the DCP is translated into the final EU Common Position, and in this exercise I will also elaborate on the two sources of information that assisted the member states in their preparation for the discussion within the working group.

The first source of information was the European Commission. This process of information gathering by the member states occurred, in many instances, prior to the submission of the initial DCP, however it did not end following this submission. Rather once the Commission had submitted the DCP to the Council working group, the delegates would frequently require further clarification and information from the Commission in order to formulate their own national positions. ${ }^{68}$

There were de-facto two avenues for requesting additional information from the Commission. One such path was formal, where during the actual working group meeting and in the presence of all delegates a member state representative would query the

\footnotetext{
${ }^{66}$ Interviewee, The Role of the Commission in Enlargement, (8 May 2009).

${ }^{67}$ Ibid.

${ }^{68}$ Miroslaw Broilo, Interview at the Polish Permanent Representation, Martin Manolov (5 May 2009).
} 
Commission representative. ${ }^{69}$ Conversely the other channel of communication between the member state and the Commission was informal, and as such precludes the question being made public to the other member state delegates, rather such were made privately between the member state representatives and the Commission official responsible for the

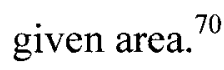

Consequently, once an issue was raised by a delegate at the working group level the Commission did not have to address this immediately or at the "highest level", meaning it did not have to be included in the agenda for further negotiation. ${ }^{71}$ In fact the Commission had the ability to address any given issue infromally by contacting the candidate state concerned, requiring them to provide the necessary information, and then presenting that to the member state or states that originally raised the issue. ${ }^{72}$

The second source of information was the representatives from the member states located on the ground at the candidate states; in this respect most member states would have their own representatives in each of the candidate states in order to be able to secure their own source of information. ${ }^{73}$ There were structures in all member states - embedded within the diplomatic delegations to each candidate states -, which dealt with the enlargement process and provided such additional information for the negotiations of the various positions at the Council working group as well as COREPER levels. ${ }^{74}$ Consequently the role of these member state representatives was to help their

\footnotetext{
${ }^{69}$ Ibid.

${ }^{70}$ Ibid.

${ }^{71}$ Babicz, Interview at the Permanent Representation of Slovakia, (5 May 2009).

${ }^{72}$ Ibid.

${ }^{73}$ Interviewee, The Role of the Commission in Enlargement, (8 May 2009).

${ }^{74}$ Mayhew, SEI Working Paper No.39, (December 2000).
} 
governments to "understand the situation on the ground" and to give them the background information that may be required. ${ }^{75}$

These experts would prepare and present situational analyses prior to the agreement of each Common Position. Large member states would also be able to use their representatives in order to verify the information presented by the Commission. ${ }^{76}$ The role of such representatives from small and medium member states however, was not so encompassing, rather their role was to highlight issues and provide more in depth information that would be most salient to the particular political and public debates in the given member state. ${ }^{77}$ This was mainly due to the fact that, unlike larger member states, the small and medium sized member states lacked the human resources to carry out more comprehensive information gathering missions. One practitioner has described the role of these member state representatives as: "parallel to the experts from the Commission" and "providing valuable information to the member states' government that had originally sent them". ${ }^{78}$ This role was even more pronounced in areas where the Commission did not hold full competencies, such as Justice and Home Affairs. ${ }^{79}$

Interestingly, the representatives of the member states located in the candidate states were "commonly" more skeptical than their colleagues in the national capitals as well as those in Brussels. ${ }^{80}$ This skepticism has been attributed to the close proximity of the former to the actual progress made by the candidate states. ${ }^{81}$ The latter however, were more concerned with the "overall picture" and the "context of the negotiation process"

\footnotetext{
${ }_{76}^{75}$ Interviewee, The Role of the Commission in Enlargement, (8 May 2009).

${ }^{76}$ Ibid.

${ }^{77} \mathrm{Ibid}$.

${ }^{78}$ Orban, Interview at the European Commission, (4 May 2009).

${ }^{79}$ Ibid.

${ }^{80}$ Interviewee, The Role of the Commission in Enlargement, (8 May 2009).

${ }^{81}$ Ibid.
} 
and as such they were more interested in finding compromises and not marginalizing themselves from the process in Brussels. ${ }^{82}$ This has most often been the case with Council representatives of small and medium member states. ${ }^{83}$ Consequently, unless a small or medium - member state had a particularly strong national interest in a given area they would not stray from the mainstream opinions. ${ }^{84} \mathrm{~A}$ common technique for identifying this mainstream was "to wait and see" what the big three (Germany, United Kingdom and France) would do. ${ }^{85}$

This has illustrated that while the member states relied on the Commission for some of the secondary information that was required for making decisions on the DCPS, they also had their own sources of information. Thereby the amendments to the DCPs proposed by the member states were not wholly dependent on the Commission, thus limiting the influence that the institution had in shaping the final incarnation of the Common Positions. The Commission however, tried to preempt problems at the working group level by judging where the average of the interests of all member states lied, thus tabling the DCPs in such a manner that was agreeable to most member states. Nevertheless, there were always issues to be discussed and areas to be amended. Consequently, all DCPs suffered some revision, this in most instances was, however, not substantial. One interviewee has suggested that between 85 and 90 percent of the Commission's proposed DCP "sailed through the Council working group". ${ }^{86}$ Therefore,

\footnotetext{
${ }^{82}$ Ibid.

${ }^{83}$ Ibid.

${ }^{84}$ Ibid.

${ }^{85}$ Ibid.

${ }^{86} \mathrm{Ibid}$.
} 
the ensuing discussions were based on "10\% or so of the text" which in the final draft was not completely altered either. ${ }^{87}$

Nevertheless, throughout the process of negotiation between the member states on each DCP, the different delegations could and did table amendment proposals. Many of the disputed issues within the working group were recurring as they had some agreed upon language included from past discussions. ${ }^{88}$ This was not always relevant to all of the member states but it was definitely a characteristic of the function of the working group. If there was disagreement between the member states on the proposed amendments the Council Presidency, with the assistance of the Commission, attempted to bridge those, and if successful the - then revised - DCP was again presented to the working group for discussion until unanimous agreement was reached. ${ }^{89}$ The ability of a member state to "push-through" any such amendments depended on the "weight of their position".90

In some instances member states would attempt to include sideline issues into the content of the DCP. ${ }^{91}$ Such included issues relating to the treatment of minorities where one member state had a similar ethnical composition as some of the minorities in the candidate state. As a result, the member state would attempt to formulate this issue as an acquis related issue where there would be higher probability to generate support from other member states. ${ }^{92}$ On the occasions where it was ambiguous whether such sideline issues were related to the acquis it was sufficient for the Commission to verify whether

\footnotetext{
${ }^{87}$ Ibid.

${ }^{88}$ Ibid.

${ }^{89}$ Ibid.

${ }^{90}$ Broilo, Interview at the Polish Permanent Representation, (5 May 2009).

${ }^{91}$ Interviewee, The Role of the Commission in Enlargement, (8 May 2009).

${ }^{92}$ Ibid.
} 
the proposed amendment was in line with the acquis. ${ }^{93}$ This is because the Commission had an institutional interest in maintaining the sanctity of the acquis. ${ }^{94}$ Consequently, if the proposed amendment was not related to the acquis, then it was simply dismissed.

Once the proposed amendments were drafted by the respective member states' delegations they were submitted to the Council Secretariat, which then circulated them to the remainder of the delegations. Once circulated the proposed amendments were then further discussed by the working group at their following meeting. ${ }^{95}$ The revised DCPs including the agreed upon amendments - were drafted by the Council Presidency in conjunction with the Council Secretariat.

It is also important to note that the revisions were often finalized following consultations with the Commission. ${ }^{96}$ The Council Presidency and Secretariat would consult the Commission because, even though it was an intergovernmental affair, the various Directorates General of the Commission were in possession of significant technical expertise and on-the-ground status information. ${ }^{97}$ This resulted from each DG taking part in assessment missions to the candidate states. Nevertheless, this consultation was a form of collegial courtesy rather than a formal requirement instilled in the process. $^{98}$

There were various avenues for a member state representative to ensure that the working group accepted their particular amendment proposals. One such avenue was to contact the various other delegations in order to garner support from other member states.

\footnotetext{
${ }_{93}^{93}$ Broilo, Interview at the Polish Permanent Representation, (5 May 2009).

${ }^{94}$ Interviewee, The Role of the Commission in Enlargement, (8 May 2009).

${ }^{95}$ Ibid.

${ }^{96}$ Ibid.

${ }^{97}$ Ibid.

${ }^{98}$ Ibid.
} 
Many of the other delegations were indifferent but some would support or conversely oppose the given amendment proposal. ${ }^{99}$ Therefore, the proposing party had to anticipate the likely outcome of their proposals, and thus identify where possible coalitions and support from other delegations could be established and conversely where they may reasonably expect to be met with resistance from other delegations. ${ }^{100}$

In the instances where there was resistance from other delegations there were techniques that were employed by the delegates in order to put pressure on the dissenting delegations to agree with the amendment proposals. One such technique, which was frequently employed, was the "silent procedure". ${ }^{101}$ Under this procedure a proposal was placed under a temporal limitation. Meaning that unless any objections were raised by a certain date the matter was considered agreed upon. This effectively tested the resolve of the delegations that generated opposition to the proposed amendments. ${ }^{102}$ Conversely, in order for the unilateral demands of a small or medium sized member state to be taken seriously at the working group level the state would have had to have particularly strong national interest in the given matter. ${ }^{103}$

When there was disagreement between two or more member state delegations it often occurred that the parties involved would meet outside of the formal setting of the working group meeting and in the presence of the Council Presidency and the Commission, where the institutions would present the political, legal and procedural aspects of either side of the issue, in an attempt for resolution. ${ }^{104}$ Whether the

\footnotetext{
${ }^{99} \mathrm{Ibid}$.

${ }^{100}$ Ibid.

${ }^{101}$ Ibid.

${ }^{102}$ Ibid.

${ }^{103}$ Ibid.

${ }^{104}$ Broilo, Interview at the Polish Permanent Representation, (5 May 2009).
} 
Commission was present depended largely on whether the issue at hand was concerning a legal or procedural aspect of the DCP. ${ }^{105}$ As a result, differences and problems were rarely solved in the formal setting of the working group meetings. This highlights the informal nature of the problem-solving procedures. One interviewee has identified this a contributing strength to the negotiation process due to the fact that it allowed the process to move forward while contentions between member states were smoothed out outside of the forum of fifteen member states, thus speeding up agreement on any particular DCP. ${ }^{106}$

Similarly, in the instances where the Commission was at odds with the proposed revisions it was the Council Presidency that tried to "smooth things out". ${ }^{07}$ This occurred occasionally because within the Council working group the Commission has, what one interviewee has described as, a "silent veto", where the expertise of the Commission carried sufficient credibility that its opinions on matters of inclusion or exclusion of issues to the DCPs could serve as a deterrent or even a block to the proposed amendment. ${ }^{108}$ In effect, on the occasions where there was significant disconnect between the member states' proposals and the Commission's evaluation of the circumstances in the candidate states, the solution was a "drafting exercise" between the Council Presidency, the member state - or states - concerned and the Commission. ${ }^{109}$ Therefore, in such cases the Presidency served as the mediator between the member states and the Commission where the supranational institution did not have any formal authority to force its position on the member states. Nevertheless, the credibility of the Commission's opinions awarded the supranational institution an informal influence over the amendment

\footnotetext{
105 Ibid.

${ }^{106}$ Interviewee, The Role of the Commission in Enlargement, (8 May 2009).

107 Ibid.

${ }^{108}$ Serpe, Interview at the Romanian Permanent Representation, (4 May 2009).

${ }^{109}$ Interviewee, The Role of the Commission in Enlargement, (8 May 2009).
} 
proposals of the member states. It should be noted however, that the ability of the Commission to exercise this informal influence depended largely on whether the presidency would invite the institution to the discussion or not. ${ }^{110}$

Consequently, at the working group level it was the Council presidency that was pivotal in the resolution of differences of opinions. However, there was a continuous working relationship between the presidency and the Commission. One interviewee has suggested that "they need each other". 111 Conversely, much also depended on the individual presidency, thus in the instances where the presidency knew the file well they would consult the Commission less than a presidency with a weaker grasp of the process and member states expectations. ${ }^{112}$ Nevertheless, the ultimate decision lay within the member states and the presidency was there to facilitate their agreement.

Finally, it is important to reiterate that the DCPs were discussed in the working group until agreement was reached. ${ }^{113}$ In the instances where agreement could not be reached the discussion was forwarded to Committee of Permanent Representatives. ${ }^{14}$ When however, agreement was achieved, the DCP was presented to the Council which then approved it as the EU Common Position. ${ }^{115}$ Edwards has suggested that over $80 \%$ of the decisions of the Council of Ministers were taken "at or below the level of COREPER". " Thus, the decision-making process followed a distinct hierarchy, where technical decisions were made at the working group level, more important decisions were

\footnotetext{
${ }^{110}$ Ibid.

111 Ibid.

${ }^{112}$ Ibid.

113 Mayhew, SEI Working Paper No.39, (December 2000).

114 Yotova, Interview at the Bulgarian Permanent Representation, (4 May 2009).

115 Nikolova, "Negotiating for EU Membership?, (2006).

116 Groffrey Edwards, "The Council of Ministers and Enlargement: A Search for Efficiency, Effectiveness and Accountability?," John Redmond and Glenda G. Rosenthal, The Expanding European Union - Past, Present, Future (Lynne Rienner Publishers, 1998) 41-65, 51.
} 
taken by COREPER and political decisions were agreed upon by the European Council. $^{117}$

The role of the Commission at this phase of the negotiation stage was far more limited than any previous phases of the enlargement process discussed in this paper. As a result of the intergovernmental nature of the discussion within the working group the institution can only be characterized as a second-class actor, at best. This is due to the fact that while the institution was in possession of an informal influence over the process, the application of this depended largely on external factors - namely the will of the Council Presidency to consult with the Commission.

Consequently, once the Commission drafted the initial DCP there were very few transaction costs associated with identifying and negotiating common strategies. In fact, the information related costs were more or less mediated by the fact that the member states had their own sources of information within the candidate states. Similarly, the Council Presidency reconciled the negotiation related costs. And lastly, there were no commitment related cost altogether; these came into effect during the substantial negotiations between the Union and the candidate states.

Conversely, an informational asymmetry still existed within this phase, the bias of which favored the Commission. This information asymmetry was due to the fact that it was the Commission - as the guardian of the treaties - that was most thoroughly informed regarding the composition of the acquis as a whole. As such, the institution was able to alter some of the proposed amendments to the DCPs, but only in the instances where such proposals were incongruent with the spirit of the acquis.

117 Interview at the European Commission, The Role of the Commission in the Accession of Bulgaria and Romania, Martin Manolov (15 May 2009). 
The third variable cannot be analyzed within this phase simply because the information required for this evaluation is not available. I am here referring to the various initial and revised DCPs, along with the minutes from the discussions within the working group, which are both classified documents. Consequently, it is not possible to determine with any certainty whether the Commission was more influential in the discussions of the DCPs that were more closely related to (former) Pillar I competencies than the ones related to (former) Pillar II and III issues.

The analysis has illustrated that at this phase of the negotiation stage the Commission was delegated duties under the agency mode. This is also evidenced by the two basic functions of the institution where it was either asked to clarify its initial submissions (the original DCPs), or it had to discern whether a proposed amendment was in line with the acquis. In either instance the institution was not awarded autonomy for further actions or proposals, rather its contributions were characterized by the rigid structure of its duties. Nevertheless, the fact that the member states trusted and consulted with the institution illustrates that the Commission has had an informal influence over the process, which was despite the fact that it was delegated duties under the agency mode. Therefore, while the majority of the evidence points to the routine administrator designation, this would not be completely accurate. As a result, at this phase of the process we could identify the role of the Commission as a routine administrator plus, thus reflecting the limited autonomy as well as the informal influence of the supranational institution. 
Section IV-The Substantive Negotiations:

Once the Council adopted a particular DCP, this then became the official EU Common Position. ${ }^{118}$ These documents were not published in the official journal and their status was something of a working document. ${ }^{119}$ These were then forwarded to the Candidate States as a response to their initial position papers. ${ }^{120}$ The Council Presidency conducted this process at Intergovernmental Conferences between the EU and the candidate states. ${ }^{121}$ Prior to the Common Position being delivered to the candidate states the Commission would evaluate the level of preparedness of the candidate states to implement the body of the acquis for any given chapter. ${ }^{122}$ This evaluation would be carried out bi-laterally between the Commission and the candidate states in the forum of sub-committee and committees of association were the member states could only assist in those meetings. ${ }^{123}$ This role was awarded to the institution because it was perceived by the member states that the Commission had a vested interest in the best possible application of the acquis by the candidate states. ${ }^{124}$ These discussions would in turn indicate to the candidate states that the Common Position on any given chapter was close to being agreed upon.

This illustrates the importance of the Common Positions for the candidate states. Therefore, it is not surprising that the negotiating teams for the candidate states attempted to gather as much information regarding the incoming Common Position as possible,

\footnotetext{
${ }^{118}$ Mayhew, SEI Working Paper No.39 (December 2000).

${ }^{119}$ Yotova, Interview at the Bulgarian Permanent Representation, (4 May 2009).

${ }^{120}$ Orban, Interview at the European Commission, (4 May 2009).

${ }_{121}^{121}$ Babicz, Interview at the Permanent Representation of Slovakia, (5 May 2009).

122 Orban, Interview at the European Commission, (4 May 2009).

${ }^{123}$ Serpe, Interview at the Romanian Permanent Representation, (4 May 2009).

${ }^{124}$ Interviewee, The Role of the Commission in Enlargement, (8 May 2009); also see: Council, 2540th General Affairs - Council Conclusions, Council of Ministers (Brussels: Council of Ministers, November 17th 2003).
} 
prior to its official introduction. Consequently, the Council working group on enlargement was an important source of information for the candidate states where their representatives would frequently contact the working group delegates in order to extract information regarding the composition of the final DCP. ${ }^{125}$ Thereby, they attempted to sidestep the Commission as the intermediary between the candidate states and the member states.

Following the presentation of the EU Common Position to the candidate states, the negotiations on any given chapter were opened. ${ }^{126}$ The number of chapters opened and closed depended on the number of DCPs that could be approved in the working group and subsequently in the Council. ${ }^{127}$ The order for opening and closing of chapters for negotiation followed an unwritten rule which established that the easiest chapters would be opened first and the most difficult chapters would be opened for negotiation last. $^{128}$ In principle the opening of the negotiation chapters was a technical decision; however, in some instances this also became a political decision. ${ }^{129}$ Consequently, the more important a chapter was the more the decision to open or close it shifted from the technical realm of the Commission to the political realm of the member states. ${ }^{130}$ Nevertheless, the Commission was able to move the process forward by proposing to open and close the various chapters. ${ }^{131}$

\footnotetext{
${ }^{125}$ Yotova, Interview at the Bulgarian Permanent Representation, (4 May 2009).

${ }^{126}$ Mayhew, SEI Working Paper No.39 (December 2000).

${ }_{128}^{127}$ Yotova, Interview at the Bulgarian Permanent Representation, (4 May 2009).

${ }^{128}$ Ibid.

${ }^{129}$ Interview at the European Commission, The Role of the Commission in the Accession of Bulgaria and Romania, Martin Manolov (15 May 2009). This interviewee however could not recollect any particular examples of this during the accession process of Bulgaria and Romania, however they did assure me that this was indeed a general practice.

${ }^{130}$ Ibid.

${ }^{131}$ Babicz, Interview at the Permanent Representation of Slovakia, (5 May 2009).
} 
The negotiations themselves were solely based on the possibility of accepting derogations and transition periods for the application of the acquis. ${ }^{132}$ This meant that in some instances bi-lateral tensions between a member state and a candidate state would become multi-lateral issues, because both the candidate states and the member states would attempt to garner more support for their position from the other member states. ${ }^{133}$ This exercise in generating support did not occur at the IGC where the EU Common Position would be initially introduced to the candidate states because the official sessions of the accession conferences were of a rather "brief and scripted" nature, which did not provide the "chance for real discussion or negotiation". ${ }^{134}$ Consequently, the candidate states "realized that the road to agreement lay not only through Brussels but also through the capitals of the member states". 135

Therefore, the process of negotiation "began long before" the proposed DCP and continued long after. ${ }^{136}$ In general however, the authorities of the candidate states provided information to the Commission and rarely directly to the member states. ${ }^{137}$ The latter would only occur if there were particular bi-lateral issues that required resolution. ${ }^{138}$ Such as the agreement between Bulgaria and Spain regarding the health insurance, pensions, unemployment benefits and family allowances for nationals residing within the territory of each state. ${ }^{139}$ Nevertheless, the candidate states would seek bilateral discussions with the member states, where the candidate state would contact the

\footnotetext{
${ }^{132}$ Avery, The Enlargement Negotiations, (Routledge, 2004).

${ }^{133}$ Yotova, Interview at the Bulgarian Permanent Representation, (4 May 2009).

${ }^{134}$ Avery, The Enlargement Negotiations, (Routledge, 2004), 40.

${ }^{135}$ Ibid, 40 .

${ }^{136}$ Ibid, 40.

${ }^{137}$ Orban, Interview at the European Commission, (4 May 2009).

${ }^{138}$ Ibid.

139 Kamen Velichkov, "Bulgaria's EU Accession Negotiations: Acheivements and Challanges," Department of Political Science int he University of Sofia, 23 August 2010 $<$ http://revistas.ucm.es/cee/15766500/articulos/PAPE0404120004A.PDF>.
} 
member state, which would in turn try to enlist the support of the Commission because of its influence within the candidate state. ${ }^{140}$ This was because the member states viewed the Commission as a particularly capable actor in finding solutions for the successful completion of the negotiations. ${ }^{141}$ This is also where the importance of the role of the Commission is rooted. ${ }^{142}$

The actual organization of the negotiations, was similar to previous enlargement rounds. ${ }^{143}$ The Council Presidency would present the applicants with the EU positions and statements; where, in some of the more difficult chapters there would be a numerous exchange of candidate state position papers and EU Common Positions. ${ }^{144}$ The volume of this exchange of documents would vary depending on the complexity of each individual chapter of the negotiations. ${ }^{145}$ Thus, in case of disagreement between the EU and the given candidate state the exchange of position papers reoccurred until agreement was reached or there was stalemate. This means that the Commission would alter the Common Position in the same process as the DCPs described in the previous section.

For example one of the main challenges for Romania was the common agricultural policy. The candidate state had to seek out many transition periods regarding the national wine registry, food safety, the production of meat and milk goods, as well as the national land registry. ${ }^{146}$ Other areas of contention were the environment, taxations, regional development, competition and justice and home affairs. ${ }^{147}$ The last chapters that were negotiated with Romania were justice and home affairs, competition and the

\footnotetext{
${ }^{140}$ Interviewee, The Role of the Commission in Enlargement, (8 May 2009).

${ }^{141}$ Orban, Interview at the European Commission, (4 May 2009).

${ }^{142}$ Ibid.

${ }^{143}$ Mayhew, SEI Working Paper No.39 (December 2000).

${ }_{144}$ Avery, The Enlargement Negotiations, (Routledge, 2004).

145 Orban, Interview at the European Commission, (4 May 2009).

${ }^{146}$ Serpe, Interview at the Romanian Permanent Representation, (4 May 2009).

${ }^{147}$ Ibid.
} 
Common Agricultural Policy, thus illustrating their complex nature. ${ }^{148}$ Bulgaria on the other hand faced challenges in the areas of competition - which was related to state aids and Justice and Home Affairs. Consequently, the member states did not want to close the Justice and Home Affairs chapter because they thought that Bulgaria was not sufficiently prepared. ${ }^{149}$ As a result, in those chapters there were a larger number of position papers exchanged prior to the final acceptance of the Common Position by the candidate state.

Consequently, the role of the Commission depended largely on what extent its institutional competencies were privy to any given chapter. ${ }^{150}$ As a result, in the chapters on competition, where the Commission had strong competencies, there was much less discussion of the proposals by the institution at the Council level. Conversely in the area of justice and home affairs where the Commission's competencies were much smaller the member states were "extremely active". ${ }^{151}$ Nevertheless, within these contentious areas (such as competition and JHA) the role of the Commission was to find technical solutions, thus the more technical the issue the larger the role for the Commission. ${ }^{152}$

Finally, upon the agreement between the EU and the candidate states each chapter was provisionally closed. ${ }^{153}$ This occurred once the chief negotiators for the given candidate state accepted the EU Common Position. ${ }^{154}$ The negotiation chapters were only provisionally closed because while the candidate states were implementing the existing acquis, the EU was generating new acquis. ${ }^{155}$ This allowed the Union to reopen any chapter for re-negotiation - where the process of submission and response by the

\footnotetext{
${ }^{148}$ Orban, Interview at the European Commission, (4 May 2009).

${ }^{149}$ Yotova, Interview at the Bulgarian Permanent Representation, (4 May 2009).

${ }^{150}$ Orban, Interview at the European Commission, (4 May 2009).

${ }^{151}$ Ibid.

${ }^{152}$ Yotova, Interview at the Bulgarian Permanent Representation, (4 May 2009).

${ }^{153}$ Mayhew, SEI Working Paper No.39 (December 2000).

${ }^{154}$ Serpe, Interview at the Romanian Permanent Representation, (4 May 2009).

${ }^{155}$ Yotova, Interview at the Bulgarian Permanent Representation, (4 May 2009).
} 
candidate states and the EU respectively, would restart - if the monitoring reports prepared by the Commission found large deficiencies in the application of the acquis by the candidate states.

The analysis of the negotiation phase of the enlargement process, similarly to the two previous phases, depends wholly on the evidence contributed through the interviews conducted by the author in 2009 . This is due to the fact that the documents that could have served as a basis for evaluation - such as the Common Positions, the position papers of the candidate states and the minutes from the negotiations-proper - are all classified. ${ }^{156}$ Nevertheless, the discussion above has illustrated that there is sufficient information in order to provide an analytical exercise with satisfactory substance.

Consequently, one can identify ample evidence suggesting that there have existed high information related transaction costs. These were found in the face of the bi-lateral evaluation of the various chapters of the acquis between the Commission and the candidate states, the technical nature of the decisions to open any given chapter for negotiation, and the function of the Commission in finding solutions for the conclusion of difficult negotiations.

Similarly, there is indication suggesting that this phase was characterized by the high negotiation related transaction costs. These are evidenced by the "brief and scripted" nature of the negotiations-proper, where the member states would follow the positions prepared within the DCPs. ${ }^{157}$ Additionally, the fact that the member states would shy away from having bi-lateral negotiations with the candidate states and would seek to involve the Commission when such were pressed for by the candidate states, also

\footnotetext{
156 The negotiations-proper here refers to the discussion between the candidate state and the member states at the Intergovernmental conferences presenting the candidate states with the EU Common Position.

${ }^{157}$ Avery, The Enlargement Negotiations, (Routledge, 2004). Also see note 42 above.
} 
points to the existence of high negotiation costs. Lastly, and maybe most importantly, the function of the Commission in finding technical solutions to problems arising in the duration of the negotiations solidifies the conclusion of the existence of high negotiation related transaction costs.

With respect to the last component of this variable - the commitment related transaction costs - these are inherently connected to the progression of the enlargement process following the negotiation stage. As such, they will be discussed in detail in the following chapter. However, it should be noted here that the outcomes of the negotiations were composed into a Draft Accession Treaty prepared by the Commission. This in turn - and depending on the empirical analysis of this Draft Accession Treaty - points to the existence of high commitment related transaction costs.

With regards to the second variable, which examines the informational asymmetry between the Commission and the member states the evidence presented is not conclusive. This is due to the fact that the candidate states would attempt to enlist the support of the member states, which provided the member states with and additional source of information to having their own representatives on the ground within the candidate states. Nevertheless, this evidence is counterbalanced by the fact that the candidate states would provide most complete information to the Commission rather than the member states. Moreover, the trust that the member states displayed towards the Commission in relying on it to find technical solutions to the problems that arose throughout the negotiations suggests that there was an informational asymmetry bias in favor of the supranational institution. In light of this, the overall conclusion can only be that there was a moderate, to high, informational asymmetry in favor of the Commission. 
The evidence illuminating the function of the institution at the various levels of its competencies is even more inconclusive than the evidence related to the previous variable. It has been identified in the discussion of the negotiation phase that in the instances where the Commission had clear competencies the member states were far less active than in the instances where the issues covered member states competencies. However, the fact of the matter remains that even in those latter cases, the member states relied on the Commission to find common solutions to the negotiation challenges at hand. As a result, it can be concluded that the technical expertise and assistance of the Commission was employed at every step of the negotiation phase of the accession process.

Consequently, the overall conclusion is that - based on the evidence presented the Commission was delegated duties to generate solutions to problems, and thereby facilitate the progress of the negotiations, in the fiduciary mode. As a result, its function within this phase is best characterized as a bureaucratic entrepreneur.

Section V-Overall Evaluation:

The negotiation stage of the enlargement process was largely dependant on the progress of the candidate states. Bulgaria and Romania were rather close to the 2004 round of enlargement and consequently they found themselves within the parameters of the same process albeit somewhat slower. The discussion of this stage of the process has illustrated that the Commission had both a formal as well as an informal role. This in turn, posed challenges for the conclusive identification of the function of the supranational institution. 
Nevertheless, this discussion presented some interesting - if not wholly unexpected - findings. With the notable exception of the phase of the member states discussion of the DCPs, the Commission has functioned as a bureaucratic entrepreneur. Conversely, at the working group phase the supranational institution was identified as a routine administrator plus, due to its informal influence over the process. This outcome is somewhat surprising given the explicitly intergovernmental nature of the negotiations between the member states. Even though the substantial negotiations between the candidate states and the Union were in principle intergovernmental in nature, this chapter has illustrated that they were de-facto driven by the various proposals of the Commission. ${ }^{158}$

The final step in the enlargement process was the preparation of the Accession Treaty between the candidate states and the Union. Following its ratification by all parties, the candidate states officially became members of the Union. The path through this final stage of the process is the focus of the following chapter.

\footnotetext{
158 Here I am mainly referring to the road map, the initial preparation of the DCPs and the yearly monitoring reports.
} 


\section{Chapter IV: The Post-Negotiation Stage}

This chapter is dedicated to the examination of the role of the Commission within the post-negotiation stage of the enlargement process. This stage is characterized by its rather brief content, which includes only the preparation of the Accession Treaty for Bulgaria and Romania and the ensuing mechanisms for Cooperation and Verification. Consequently, this chapter is thus divided among the discussion of these two phases. Despite the brief nature of this discussion, the importance of it to the accession of the two candidate states is paramount. Furthermore, while the preparation of the Accession Treaty is an inescapable component of each enlargement round, the Cooperation and Verification Mechanisms (CVM) applied to this round identifies the accession of Bulgaria and Romania as quantitatively different from any previous enlargement in the Union. Therefore, while a brief analysis of the Accession Treaty phase will be provided, it is the creation and application of the CVM that will be the focus of this chapter.

Section I-The Accession Treaty:

In 2003 the Commission presented a strategy paper, which suggested that "in order for accession to take place in 2007, a common Accession Treaty for Bulgaria and Romania should be signed at the latest towards the end of 2005". The 2007 date of accession was proposed by the candidate states themselves. This in turn, meant that the substantive negotiations should be completed in $2004 .^{2}$ This date for accession was confirmed by the Thessaloniki European Council at its meeting in June of $2003 .^{3}$

1 Commission, CONTINUING ENLARGEMENT Strategy paper and Report fot the European Commission on the progress towards accession by Bulgaria, Romania and Turkey, European Commission (Brussles: European Commission, November 5th 2003), 12.

${ }^{2}$ Ibid.

3 European Council, Presidency Conclusions, European Council (Thessaloniki: European Council, June 2003). 
Following the 2003 strategy paper the Council at its meeting on November $17^{\text {th }}$ of 2003 discussed the proposals of the Commission and as a result, stated that it "shares the analysis and main conclusions drawn by the Commission". Consequently, the European Council in December of 2003 urged the candidate states to further the progress of their reforms so that "the Accession Treaty [could] be signed as soon as possible in 2005 ". 5

During its meeting in June of 2004, the European Council reiterated the goal of signing the Accession Treaty "as early as possible in 2005 " 6 To this effect the heads of state pronounced that the drafting of the Accession Treaty "will begin in July 2004". 7 The European Council also expressed its anticipation of the 2004 reports by the Commission. ${ }^{8}$ By December of 2004 all of the chapters where substantial negotiations between the Union and the candidate states were previously still in progress had been closed. Shortly prior to this the Commission presented its 2004 strategy paper where the institution confirmed that the work on preparing the Accession Treaty had indeed begun in July of the same year. ${ }^{9}$

More importantly, however, in this report the Commission proposed the inclusion of, so-called, safeguard clauses into the Accession Treaty. These clauses were a "last resort mechanism" and included the areas of general economic concerns, issues related to the internal market, and problems under the category of Justice and Home Affairs. ${ }^{10}$

4 Council, 2540th General Affairs - Council Conclusions, Council of Ministers (Brussels: Council of Ministers, November 17th 2003), 8.

5 European Council, Presidency Conclusions, European Council (Brussels: European Council, December 2003), 11.

${ }^{6}$ European Council, Presidency Conclusions, European Council (Brussels: 1, June 2004), 7.

${ }^{7}$ lbid, 7.

${ }^{8}$ Ibid.

9 Commission, COMMUNICATION FROM THE COMMISSION TO THE COUNCIL AND TO THE EUROPEAN PARLIAMENT Strategy Paper of the European Commission on progress in the enlargement process, European Commission (Brussels: European Commission, October 6th 2004).

${ }^{10}$ Ibid, 4 . 
Furthermore, the Commission proposed a "specific safeguard", which was to allow the Commission - on the basis of its monitoring exercises - to propose to the Council the delaying of the accession of the candidate states for one additional year, until January of $2008 .^{11}$

Consequently, in December of 2004 the European Council reviewed these proposals of the Commission, and "welcomed its findings and recommendations". 12 More importantly, the European Council stated that "the safeguard clauses will provide for measures to address serious problems that may arise before accession ..." ${ }^{13}$ Lastly, the heads of state called for the conclusion of the Accession Treaty in time for the April 2005 General Affairs Council meeting. ${ }^{14}$ As a result, the European Council wholly endorsed the proposals of the Commission.

As requested, the Accession Treaty was approved on February $11^{\text {th }}$ of 2005 and subsequently signed by the candidate states and the member states on April $25^{\text {th }}$ of the same year. ${ }^{15}$ The Accession Treaty itself was relatively short and straightforward similar in nature to the previous accession round. ${ }^{16}$ However, the 2005 Accession Treaty also included an Accession Protocol and a total of nine Annexes. ${ }^{17}$ The Annexes included the agreements on various issues, from the provisions of the Schengen acquis, to the specific commitments for rural development. Most important however, were Articles 36

\footnotetext{
${ }^{11}$ Ibid, 4.

12 European Council, Presidency Conclusions, European Council (Brussels: European Council, December 2004), 2.

${ }^{13}$ Ibid, 3 .

${ }^{14}$ Ibid.

15 Council, 2655th General Affairs - Council Conclusions, Council of Ministers (Brussels: Council of Ministers, April 25th 2005).

16 Council, TREATY CONCERNING THE ACCESSION OF THE REPUBLIC OF BULGARIA AND ROMANIA TO THE EUROPEAN UNION, Council of Ministers (Brussles: Council of Ministers, June 21 2005).

${ }^{17}$ The Accession Treaty also included an Act of Accession, which was in place in case that the candidate states did not join the Union in 2007. This act was identical to the Accession Protocol, and given the fact that Bulgaria and Romania did join in 2007 the Act of Accession is not discussed any further here.
} 
to 39 of the Protocol of Accession. These in effect codified, in the rigid legal basis of the Treaty of Accession, the safeguard clauses proposed by the Commission in its 2004 strategy paper. $^{18}$

Following the signing of the Accession Treaty, in October of 2005 the Commission prepared its comprehensive monitoring report, which outlined the areas where further and more intensified reforms by Bulgaria and Romania, were required. ${ }^{19}$ This report and its recommendations - to the candidate states - were accepted by the General Affairs Council during its meeting on December $15^{\text {th }}$ of $2005 .^{20}$ Moreover, the Council "welcomed the intention of the Commission to submit a monitoring report to the Council and Parliament in April/May 2006 in order to review the situation in line with the provisions of the Accession Treaty". ${ }^{21}$ Diligently, on May $16^{\text {th }}$ of 2006 the Commission presented its monitoring report. The main findings identified that "Bulgaria and Romania should be prepared for membership by 1 January 2007 provided they address a number of outstanding issues". ${ }^{22}$ In order to ensure this the Commission also stated that it would prepare another such report by October of $2006 .^{23}$ This report and the subsequent development and implementation of the Cooperation and Verification Mechanisms are the subject of the following section of this chapter.

However, prior to this discussion, attention should be awarded to the empirical

18 Council, PROTOCOL Concerning the conditions and arrangements for admission of the republic of Bulgaria and Romania to the European Union, Council of Ministers (Brussels: Council of Ministers, June 21 st 2005).

19 Commission, COMMUNICATION FROM THE COMMISSION Comprehensive monitoring report on the state of preparedness for EU membership of Bulgaria and Romania, European Commission (Brussels: European Commission, October 25th 2005).

20 Council, 2700th General Affairs - Council Conclusions, Council of Ministers (Brussels: Council of Ministers, December 15th 2005).

${ }^{21}$ Ibid, 11.

22 Commission, COMMUNICATION FROM THE COMMISSION Monitoring report on the state of preparedness for EU membership of Bulgaria and Romania, European Commission (Brussels: European Commission, May 16th 2006), 11.

${ }^{23}$ Ibid. 
analysis of the current section. Consequently, with respect to the first variable - that is the level of transaction costs associated with identifying and negotiating common strategies - the evidence suggests that there were indeed high information related costs. This is to a large extent a factor carried over from the previous chapter. Such overlap, is the result of the fact that the monitoring reports - which formed the basis of the Commission's strategy papers - referred to in this chapter are in methodology and execution a carbon copy of the reports discussed in the previous chapter. ${ }^{24}$

The substance however, is different. As such, the evidence from this substance has illustrated that the negotiation as well as commitment related transaction costs associated with this phase of the post-negotiation stage were high. The fact that the Commission proposed the inclusion of the safeguard clauses informs the conclusion that there were high commitment related costs. This is subsequently supported by the endorsement of this proposal by the member states. Similarly, the fact that it was the Commission that drafted the Accession Treaty substantiates the claim that there were high negotiation related costs.

Regarding the second variable, the evidence suggests that the informational asymmetry was in favor of the supranational institution. This evidence, similarly to the first component of the previous variable, finds its roots in the discussion of Chapter III. As the analysis of the negotiation stage has illustrated, the Commission was the institution most familiar with the on-the-ground circumstances of the candidate states. Therefore, it was the Commission that was best equipped to prepare the various components of the Accession Treaty. Lastly, the third variable, which measures the influence of the Commission under the various areas and competencies, cannot be

\footnotetext{
${ }^{24}$ See page 67.
} 
evaluated in this phase of the process. This is due to the fact that the original Draft Accession Treaty prepared by the Commission is not available for review. Consequently, there is not sufficient evidence in order to determine whether the supranational institution was more influential in the areas under its own competencies or not.

Nevertheless, on the basis of the former discussion and despite the fact that most of the substance of the Accession Treaty was a incarnation of the outcome of the substantive negotiations it can be concluded that the Commission was awarded duties the result of which was the creation of the Accession Treaty - under the fiduciary mode. This is largely due to the fact that the Commission did propose the safeguard clauses and the member states accepted their incorporation into the Accession Treaty.

As a result, the institution was able to shape the strategies chosen by the member states in order to accomplish their initial objectives. This is most explicitly evidenced by the fact that the member states did include the proposed safeguard clauses within the Accession Treaty. Nevertheless, these safeguard clauses were only one component of the Treaty and therefore, the role of the Commission at this phase cannot be unequivocally described as that of a bureaucratic entrepreneur, rather a more appropriate designation would be bureaucratic entrepreneur minus. Consequently, this takes account of both the fact that the supranational institution did make additional proposals to the Accession Treaty, and the fact that the substance of the Treaty, as such, was mostly grounded in the conclusions of the substantive negotiations.

Section II-The Cooperation and Verification Mechanism:

The monitoring report prepared by the Commission in October of 2006 gave the seal of approval for the preparedness of the Bulgaria and Romania to accede in 2007. The 
report stated: "As a result of the progress made, Bulgaria and Romania will be in a position to take on the rights and obligations of EU membership on 1 January 2007 ". ${ }^{25}$

Nevertheless, on the basis of its monitoring exercise, the supranational institution also identified that both Bulgaria and Romania were still lagging in the areas of "judicial reform and the fight against organized crime and corruption". ${ }^{26}$ As a result, the institution proposed that it should "establish a mechanism to cooperate and verify progress in these areas after accession". ${ }^{27}$ This mechanism was to be based on Articles 37 and 38 of the protocol of accession. ${ }^{28}$

The substance of the Cooperation and Verification Mechanism (CVM) was a set of benchmarks, which the two countries were supposed to meet. Table I below presents these benchmarks as they have been developed by the Commission.

\begin{tabular}{|l|l|}
\hline \multicolumn{2}{|c|}{ Table I: The Benchmarks under the CVMs for Bulgaria and Romania ${ }^{29}$} \\
\hline \multicolumn{1}{|c|}{ Bulgaria: } & \multicolumn{1}{c|}{ Romania: } \\
\hline $\begin{array}{l}\text { - Adopt constitutional amendments removing any } \\
\text { ambiguity regarding the independence and }\end{array}$ & $\begin{array}{l}\text { - Ensure a more transparent, and efficient judicial } \\
\text { accountability of the judicial system. }\end{array}$ \\
$\begin{array}{l}\text { process notably by enhancing the capacity and } \\
\text { accountability of the Superior Council of } \\
\text { Magistracy. Report and monitor the impact of the } \\
\text { new civil and penal procedures codes. }\end{array}$ \\
$\begin{array}{l}\text { process by adopting and implementing a new } \\
\text { judicial system act and the new civil procedure } \\
\text { code. Report on the impact of these new laws and of } \\
\text { the penal and administrative procedure codes, } \\
\text { notably on the pre-trial phase. }\end{array}$ & $\begin{array}{l}\text { - Establish, as foreseen, an integrity agency with } \\
\text { responsibilities for verifying assets, } \\
\text { incompatibilities and potential conflicts of interest, } \\
\text { and for issuing mandatory decisions on the basis of } \\
\text { which dissuasive sanctions can be taken. }\end{array}$ \\
$\begin{array}{l}\text { - Continue the reform of the judiciary in order to } \\
\text { enhance professionalism, accountability and } \\
\text { efficiency. Evaluate the impact of this reform and } \\
\text { publish the results annually. }\end{array}$ & $\begin{array}{l}\text { - Building on progress already made, continue to } \\
\text { conduct professional, non-partisan investigations } \\
\text { into allegations of high-level corruption. }\end{array}$ \\
$\begin{array}{l}\text { Conduct and report on professional, non-partisan } \\
\text { investigations into allegations of high-level } \\
\text { corruption. Report on internal inspections of public }\end{array}$ & $\begin{array}{l}\text { - Take further measures to prevent and fight against } \\
\text { corruption, in particular within the local } \\
\text { government. }\end{array}$ \\
\hline
\end{tabular}

25 Commission, COMMUNICATION FROM THE COMMISSION Monitoring report on the state of preparedness for EU membership of Bulgaria and Romania, European Commission (Brussels: European Commission, October 26th 2006), 13.

${ }^{26}$ Ibid, 9.

${ }^{27}$ lbid, 9.

${ }^{28}$ This was discussed in the previous section. See page $110-111$.

${ }^{29}$ Commission, Monitoring report, (October 26th 2006), 10. 


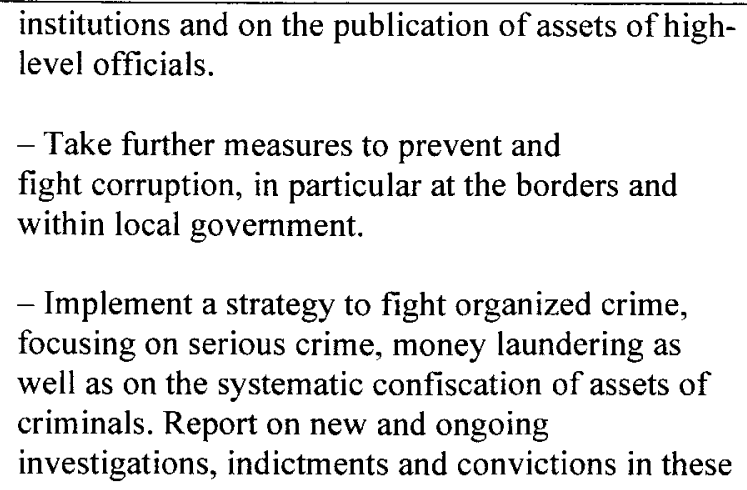

In order to aid the candidate states with meeting these benchmarks the Commission proposed to provide "internal and external expertise" and assist in the reform process. ${ }^{30}$ Consequently, the candidate states were required to report regularly on the progress of meeting each of the benchmarks. In turn the Commission was to verify and report its findings to the member states. In addition, a major component of the CVM was the fact that it would continue its existence until the benchmarks have been fully met. ${ }^{31}$

Conversely, if the two states "failed to address the benchmarks adequately", the Commission proposed that the safeguard measures within the Accession Treaty should be invoked. ${ }^{32}$ This meant that Bulgaria and Romania would face the "suspension of current Member States' obligation to recognize those judgments and execute warrants issued by either country's courts or prosecutors falling under the principle of mutual recognition". ${ }^{33}$ Finally, the Commission suggested that it should "adopt a decision implementing and defining the modalities of this mechanism after consulting the member states" which would become effective at the date of accession of the two candidates January $1^{\text {st }} 2007 .^{34}$

\footnotetext{
${ }^{30}$ Ibid.

${ }^{31}$ Ibid.

${ }^{32}$ Ibid, 10.

${ }^{33}$ Ibid, 10 .

${ }^{34}$ Ibid, 10.
} 
Consequently, on October $17^{\text {th }}$ of 2006 the General Affairs Council welcomed the report presented by the Commission in the same month. More importantly, the Council stated that it "supports the mechanism to be set up for cooperation and verification of the progress in the area of judicial reform and the fight against organized crime". ${ }^{35}$ The Council also reiterated that the purpose of the CVM was to ensure the adequate functioning of the EU following the accession of the two countries. ${ }^{36}$ Lastly, the member states urged Bulgaria and Romania to finalize their reforms in light of the 2007 accession date. These conclusions of the Council were in effect restated at its meeting on December $11^{\text {th }}$ of the same year. ${ }^{37}$ Consequently, the Council endorsed the proposed creation and implementation of the CVM in its entirety. It was with the endorsement of this final postaccession requirement that the European Council in December of 2006 "warmly welcome[d] Bulgaria and Romania as members of the European Union on 1 January $2007 "{ }^{38}$ For the heads of state, this identified the conclusion of the fifth round of enlargement of the European Union. ${ }^{39}$

One day following the declaration by the European Council, on December $13^{\text {th }}$ of 2006, the Commission adopted the decisions, on the basis of which the individual CVMs for Bulgaria and Romania came into force. ${ }^{40}$ The texts of these two decisions were a

35 Council, 2755th General Affairs - Council Conclusions, Council of Ministers (Brussels: Council of Ministers, October 17th 2006), 7.

${ }^{36}$ Ibid.

37 Council, 2770th General Affairs - Council Conclusions, Council of Ministers (Brussles: Council of Ministers, December 11th 2006).

38 European Council, Presidency Conclusions, European Council (Brussels: European Council, December 2006), 2.

${ }^{39}$ Ibid.

40 Commission, COMMISSION DECISION of 13 December 2006 establishing a mechanism for cooperation and verification of progress in Bulgaria to address specific benchmarks in the areas of judicial reform and the fight against corruption and organised crime, European Commission (Brussels: European Commission, December 13th 2006), and Commission, COMMISSION DECISION of 13 December 2006 establishing a mechanism for cooperation and verification of progress in Romania to address specific benchmarks in the areas of judicial reform and the fight against corruption (notified under document 
carbon copy of the proposals presented by the institution in its 2006 strategy paper. As such, they included all of the responsibilities of the two countries, as well as the responsibilities of the Commission in implementing the CVMs.

While the enlargement process ended with the accession of Bulgaria and Romania on January $1^{\text {st }}$ of 2007 , the CVMs established at its very conclusion was, and still is to this date, very much in place. Therefore, at the point of accession the CVMs became a policy process internal to the Union, and are as such, outside of the scope of this work. This is because following the conclusion of the enlargement process the functional environment shifts to the implementation stage where the role of the Commission is to "put the accession treaties into effect". ${ }^{41}$ Despite this however, the CVMs have their distinct origins in the enlargement process, as such this warrants - in the interests of continuity to the discussion at hand - at least a basic overview. As such, the following is a limited description of the progress of the application of the CVMs up to the present date. $^{42}$

Following the decisions of the Commission establishing the CVMs as a EU policy process, the supranational institution has provided the member states with reports on the progress of the two countries starting in the fall of 2007 and then bi-annually for year subsequent year. The purpose of these reports was to a) identify the progress of each country in meeting the benchmarks, b) to determine where further reforms and efforts were required, and c) to inform the member states whether any of the safeguard clauses

number $\mathrm{C}(2006)$ 6569) (2006/928/EC), European Commission (Brussels: European Commission, December 13th 2006).

41 Desmond Dinan, "The Commission and Enlargement," John Redmond and Glenda G. Rosenthal, The Expanding European Union - Past. Present, Future (Lynne Rienner Publishers, 1998) 17-41, 22.

${ }^{42}$ For more information on the Cooperation and Verification Mechanisms see the European Commission website and the following url: http://ec.europa.eu/dgs/secretariat_general/cvm/progress_reports_en.htm 
will be applied. At every step of this period, the Council has supported the findings of the Commission reports and has reiterated the need for Bulgaria and Romania to further their progress on the basis of the recommendations of the Commission. Lastly, it should be also noted that the European Council has not commented on the CVMs, or their implementation, since the approval of the safeguard clauses within the Accession Treaty, which, we can recall, served as the basis for the creation of the CVMs. As I had mentioned at the outset of this discussion, the CVMs are still in place and consequently, it remains to be seen when the two countries will meet all of the benchmarks, thus marking the satisfactory conclusion of the CVMs.

The evidence presented in the above discussion suggests the existence of high information as well as commitment related transaction costs. The information related costs were the result of the fact that the recommendations to create the CVMs were based on the extensive monitoring reports prepared by the Commission. In turn, the existence of the high commitment related transaction costs is evidenced through the fact that the member states wholly agreed that it was to be the Commission that was responsible for the implementation of the processes under the CVMs. Conversely, the third component of the first variable cannot be evaluated at this phase of the post-negotiation stage, simply because the proposed CVMs did not require any negotiations. This was due to the fact that the mechanisms came into force as a decision from the Commission and were as such, a piece of secondary legislation, rather than a subject of negotiation between the member states.

With respect to the second variable that evaluates the role of the Commission, the evidence clearly identifies an informational asymmetry, the bias of which favored the 
Commission. This was because the creation of the CVM was based on the monitoring reports, which the previous chapters identified as a phase where the informational asymmetry was in favor of the supranational institution. Conversely, the evidence illuminating the third variable is perhaps more explicit at this phase of the enlargement than any other previously examined. This is due to the application of the CVMs, which were dependent on a decision of the Commission, thus identifying them as distinctly within the competencies of the institution. This is notwithstanding the fact that the Commission consulted the member states prior to formally making this decision.

In fact, the unequivocal approval of the CVMs by the member states, combined with the other evidence, simply confirms the supposition that the Commission was delegated the duty for their creation and implementation in the fiduciary mode. Consequently, it can be concluded that at this phase the role of the Commission can only be defined as a bureaucratic entrepreneur.

Section III-Overall Evaluation:

The post-negotiation stage of the enlargement process was characterized by the relatively little involvement of the member states, which is despite the fact that it was the member states that had to agree upon the final text of the Accession Treaty. This assertion is based on the understanding that while the signing of the Treaty was an intergovernmental process, the content of this was mostly agreed upon at the previous negotiation stage. In effect the Accession Treaty was a mainly conglomeration of the outcomes of the negotiations of the various chapters of the acquis, notwithstanding the addition of the safeguard clauses. Consequently, the drafting of the Treaty by the 
Commission provided the fusion of all these previous discussion a legal and binding character.

Moreover, in both phases of this stage, the Commission was delegated duties under the fiduciary mode. As a result the evidence presented has identified that the Commission was able to shape the strategy for the successful conclusion of the accession process, which in itself was the first order preference of the member states. Consequently, the overall evaluation of the role of the institution at this stage of the enlargement process has been established as a bureaucratic entrepreneur. 


\section{Conclusion}

In this thesis I have attempted to provide a vivid picture of the inter-institutional interactions between the European Commission and the member states while complementing this with an empirical analysis, which was aimed at narrowing the gap between the contrasting academic conceptualizations of the role of the Commission within the enlargement of the Union. Consequently, following the review of this literature and the identification of the said gap, I presented in Chapter I a theoretical framework for empirical analysis. This framework identified three variables - the transaction costs associated with the identification and negotiation of common strategies, the informational asymmetry distribution between the supranational institution and the member states, and the distribution of competencies - which once empirically measured and depending on the outcome of that analysis either suggested that the Commission was delegated duties under the fiduciary or the agency modes. In turn, this delegation was either to result in the institution being able to influence the strategies for the attainment of the objectives of the member states, thus being characterized as a bureaucratic entrepreneur, or conversely it was to simply have administrative functions without influence, thus being characterized as a routine administrator.

At the very outset of this paper I have illustrated that while the Commission is the primary actor in areas related to the internal market, - which is due to its right to initiate legislation - the institution was expected to be far less influential in areas of external relations, such as the enlargement policy of the Union. Nevertheless, I also identified this expectation as an assumption and as such the basis for empirical evaluation. Among the various areas of external relations that could serve as the case study for such evaluation I 
suggested that the enlargement policy of the EU, and in particular the path of accession for Bulgaria and Romania, offers a particularly fruitful soil for analysis. On the basis of the former assumption I proposed that one would most likely expect the role of the supranational institution to be best characterized as a routine administrator in its functions related to the EU's enlargement policy.

Consequently, in the three empirical chapters of this paper I ventured to carry out this empirical evaluation on the basis of the three variables developed in the first theoretical chapter. As such, I had proposed a division of the enlargement into three stages, the pre-negotiation, negotiation, and post-negotiation. These reflected the various milestones of the inter-institutional interaction between the member states and the Commission along the process. A detailed presentation of the results of this analysis were presented at the conclusion of each section and then summarized at the conclusion of each chapter. Therefore, this exercise will not be repeated here. Rather, I will present an overall conclusion of the empirical analysis in order to provide an answer to the research question presented in the introduction of this work. To serve as a reminder this research question asked: What was the role of the European Commission within the accession of Bulgaria and Romania to the European Union?

Contrary to the initial expectation the outcome of the analysis has illustrated that the Commission has been supremely influential in the accession of Bulgaria and Romania. In fact, I have identified the role of the institution as a bureaucratic entrepreneur at almost every single milestone of the process. More importantly, even at the purely intergovernmental stage of the negotiation of the Draft Common Positions by the member states, the supranational institution proved to have a "silent veto", - due to 
its significant technical expertise and knowledge of the reforms within the candidate states - which allowed the institution to affect the amendments to the various DCPs proposed by the member states. Consequently, the response to the research question is that overall the European Commission has acted as a bureaucratic entrepreneur throughout the accession of Bulgaria and Romania to the European Union.

It may however, be contended that the accession of these two countries is a singular historic instance event, never to be repeated again, which would render the outcomes of the analysis carried out in this paper not transferable. Such criticism is based on the understanding that the Union was prompted to accept these two states prior to their full implementation of the requisite reforms. ${ }^{1}$ The impetus for this decision, it has been argued, was that a) Bulgaria and Romania had suffered economically by supporting the Union in its sanctions of former Yugoslavia, and b) that the political stability of the region would have been undermined if they did not gain membership. ${ }^{2}$ As a result, the Union decided to apply the Cooperation and Verification Mechanism as a post accession tool to mediate the incomplete nature of the reforms of the two countries. However, this contention does not take into account the fact that the current enlargement process includes benchmarks - similar in style and function to the ones established as a main component of the CVM - within the fabric of the Common Positions of the Union for each individual chapter for substantive negotiations. ${ }^{3}$ This suggests that while the accession of Bulgaria and Romania was different from the accession of the ten Central

\footnotetext{
1 Carmen Hubbard and Lionel Hubbard, "Bulgaria and Romania: Paths to EU Accession and the Agricultural Sector," Centre for Rural Economy Discussion Paper Series No. 17 July 2008: 1-21.

2 Pavlina Nikolova, "Negotiating for EU Membership? - The Case of Bulgaria and Romania," Croatian Yearbook of European Law and Policy 2.1 (2006): 393-412; David Phinnemore, "Enlargement to the East: Romania," Hilary Ingham and Mike Ingham, EU Expansion to the East - Prospects and Problems (Edward Elgar, 2002) 222-245.

${ }^{3}$ State which countries have this applied to, which have negotiations going on.
} 
and Eastern European states in 2004, it has much more in common with the current enlargement process.

In addition the outcome of the analytical exercise suggested that the current incarnation of principal-agent theory requires some revision. The fact that the institution was found to function as a bureaucratic entrepreneur throughout most of the enlargement process suggests that the Commission has been able to autonomously generate policyimplementation strategies that had some positive outcomes for the member states. This in turn means that the principal-agent relationship can also be characterized by the positive influence of the agent's autonomy. Recalling Pollacks' arguments discussed in Chapter one, this is contrary to this authors' assertion that the autonomy of the agent, if left unchecked, would have negative consequences of the principals.

Lastly, the conclusions of this paper suggest that since the Commission has had a significant influence over this area of external relations, it is possible to argue that the institution may be equally influential in other external relations policy fields, such as: external economic policy, Common Foreign and Security Policy and Common Security and Defense Policy (CSDP). This supposition is grounded in the understanding that the member states would delegate additional duties to the Commission, accompanied with autonomy for their fulfillment on the basis of three main factors, all of which find their basis in the analytical exercise conducted in this paper. These factors are: a) the member states perceive of the supranational institution as a guardian of the treaties, $b$ ) the member states concur that the supranational institution has a strong interest in the best possible application of the acquis, and c) the Commission has a significant technical expertise and ability to generate policy-relevant information and its opinion therefore, provides a 
invaluable contribution to the overall understanding of the given policy area by the member states. ${ }^{4}$

With regards to the external economic policy of the European Union, it has been ascertained that the competencies of the supranational institution are supreme to those of the member states. ${ }^{5}$ This was the result of the "division of European foreign policy into two fundamentally different component" following the introduction of the EU Pillar structure by the TEU. ${ }^{6}$ Conversely, the CFSP has remained very much within the competencies of the member states. More importantly, the CFSP does not share the same peculiar structure within the Union's policies as enlargement policy. Therefore, it would be most difficult to argue that the supranational institution may carry the same influence in this area as in the field of enlargement. Most notably this difficulty arises from the fact that the Commission would not be involved as the guardian of the treaties under the precepts of this policy field. Nevertheless, the fact remains that the supranational institution, with its significant technical expertise may be able to meaningfully contribute to the creation of policy alternatives and strategies for the attainment of the objectives of the member states. Consequently, only thorough empirical evaluation may one determine the nature of the role of the Commission within the Common Foreign and Security Policy of the Union.

\footnotetext{
${ }^{4}$ Commission, "EUROPA," 2001, Enlargement of the European Union - An historic opportunity, European Commission, 02 April 2009 http:/ec.europa.cu/enlargement/archives/pdf press comer/publications/corpus en.pdf; Interviewee from a Member State Permenent Representation, The Role of the Commission in Enlargement, Martin Manolov (8 May 2009).

5 Stefan Griller and Brigit Weidel, "External Economic Relations and Foreign Policy in the European Union," Stefan Griller and Brigit Weidel, External Economic Relations and Foreign Policy in the European Union (Wien: Springer-Verlag, 2002) 5-23.

${ }^{6}$ Ibid, 6.
} 


\section{Bibliography}

Avery, Graham. "The Enlargement Negotiations." Cameron, Fraser. The Future of Europe - Integration and Enlargement. Routledge, 2004. 35-63.

Baldwin, Richard E. "The Eastern enlargement of the European Union." European Economic Review 39 (1995): 474-481.

Baldwin, Richard, Joseph F. Francois and Richard Portes. "The costs and benefits of eastern enlargement: the impact on the EU and central Europe." Economic Policy 12.24 (2002).

Baun, Michael J. A Wider Europe: The Process and Politics of European Union Enlargement. Rowman \& Littlefield Publishers Inc., 2000.

Bretherton, Charlotte and John Vogler. "Actors and actorness in global politics: Locating the European Union." The European Union as a Global Actor. Routledge, 1999. 15-46.

Carmen Hubbard and Lionel Hubbard, "Bulgaria and Romania: Paths to EU Accession and the Agricultural Sector," Centre for Rural Economy Discussion Paper Series No. 17 July 2008: 1-21.

Cini, Michelle. The European Commission - Leadership, organisation and culture in administration. Manchester and New York: Manchester University Press, 1996.

Dehaene, Jean-Luc, David Simon and Richard von Weizsacker. The Institutional Implication of Enlargement: Report to the European Commission. Brussels: European Commission, 1999.

Dinan, Desmond. "National Interests and Supranational Solutions." Europe Recast A History of European Union. Lynne Rienner, 2004. 321-323.

-. "The Commission and Enlargement." Redmond, John and Glenda G. Rosenthal. The Expanding European Union - Past, Present. Future. Lynne Rienner Publishers, 1998. 17-41.

Edwards, Groffrey. "The Council of Ministers and Enlargement: A Search for Efficiency, Effectiveness and Accountability?" Redmond, John and Glenda G. Rosenthal. The Expanding European Union - Past, Present, Future. Lynne Rienner Publishers, 1998. 41-65.

Fearon, James and Alexander Wendt. "Rationalism Vs. Constructivism: A Skeptical View." Carlsnaes, Walter, Thomas Risse and Beth A. Simmons. Handbook of International Relations. London: SAGE, 2002. 52-73. 
Finnemore, Martha. National Interests in International Scociety. Cornell University Press, 1996.

Franco, Marc. "The enlargement: the European Commission's viewpoint." Price, Victoria Curzon, Alice Landau and Richard G Whitman. The Enlargement of the European Union - Issues and Strategies. London \& New York: Routledge, 1999. 6776.

Frey, Frederick W. "The Problem of Actor Designation in Political Analysis." Comparative Politics 17.2 (1985): 127-152.

Friis, Lykke and Anna Murphy. "Enlargement: A Complex Juggling Act." Cowles, Maria Green and Michael Smith. The State of the European Union - Risks, Reform, Resistance, and Revival. Oxford University Press, 2000. 186-207.

Geddes, Barbara. Paradigms and Sand Castles: Theory Building and Research Design in Comparative Politics. University of Michigan Press, 2003.

Grabbe, Heather. The EU's Transformative Power - Europeanisation Through Conditionality in Central and Eastern Europe. New York: Palgrave, 2006.

Griller, Stefan and Weidel, Brigit. "External Economic Relations and Foreign Policy in the European Union," Stefan Griller and Brigit Weidel, External Economic Relations and Foreign Policy in the European Union (Wien: Springer-Verlag, 2002) $5-23$.

Hooghe, Liesbet and Gary Marks. Multi-Level Governance and European Integration. Rowman \& Littlefield Publishers, INC., 2001.

-. "Principal or Agent." Hooghe, Liesbet. The Euroepan Commission and the Integration of Europe - Images of Governance. Cambridge University Press, 2001. 142-168.

Hix, Simon. The Political System of the European Union. New York: St. Martin's Press, 1999.

Inotai, Andras. "The CEECs: From the Association Agreements to Full Membership?" Redmond, John and Glenda G. Rosenthal. The Expanding European Union - Past, Present, Future. London: Lynne Rienner Publishers, 1998. 157-177.

Kaiser, Wolfram and Peter Starie. "The European Union as a transnational political space: Introduction." Kaiser, Wolfram and Peter Starie. Transnational European Union - Towards a Common Political Space. London and New York: Routledge, 2005. 1-15. 
Majone, Giandomenico. "Delegation of Power and the Feduciary Principle." Dilemmas of European Integration: The ambiguities and pitfalls of integration by stealth. Oxford University Press, 2005. 64-82.

Maleeva, Snejana. "Bulgaria's Accession to the European Union." Neuwahl, Nanette. European Union Enlargement - Law and Socio-Economic Changes. les edition themis, 2003. 255-265.

Mayhew, Alan. "Enlargement of the European Union: An Analysis of the Negotiations with the Central and Eastern European Candidate Countries." SEI Working Paper No.39 December 2000: 2-71.

- Recreating Europe - The European Union's Policy towards Central and Eastern Europe. Cambridge University Press, 1998.

Moravcsik, Andrew and Milada Anna Vachudova. "Bargaining Among Unequals: Enlargment and the Future of European Integration." European Union Studies Association 15.4 (2002).

-. "National Interests, State Power, and EU Enlargment." East European Politics and Scocieties 17.1 (2003): 42-57.

-. "Preferences, power and equilibrium: the causes and consequences of EU enlargement." The Politics of European Union Enlargement. Ed. Frank Schimmelfennig and Ulrich Sedelmeier. Routledge, 2005. 198-213.

Moravcsik, Andrew. The Choice for Europe: Social Purpose and State Power form Messina to Maastricht . Cornell University Press, 1998.

Neunreither, Karlheinz and Antje Weiner. European Integration After Amsterdam Institutional Dynamics and Prospects for Democracy. Oxford: Oxford University Press, 2000.

Nikolova, Pavlina. "Negotiating for EU Membership? - The Case of Bulgaria and Romania." Croatian Yearbook of European Law and Policy 2.1 (2006): 393-412.

Nugent, Neill. "The Unfolding of the 10+2 Enlargement Round." Nugent, Neill. European Union Enlargement. New York: Palgrave, 204. 34-56.

-. The European Commission. New York: Palgrave, 2001.

O'Brennan, John. "The European Commission and eastern enlargement; Conceptualising eastern enlargement." The Eastern Enlargement of the European Union. Routledge, 2006. 74-95; 113-172. 
Page, Edward C. People Who Run Europe. Oxford: Claredon/Oxford University Press, 1997.

Paraskevopoulos, Christos. "EU Enlargement and Multi-Level Goverannce in European Public Policy-Making: Actors, Institutions and Learning." Paraskevopoulos, Christos, Panagiotis Getimis and Nicholas Rees. Adapting to EU Multi-Level Governance - Regional and Environmental Policies in Cohesion and CEE Countries. Ashgate, 2006. 3-25.

Piazolo, Daniel. The Integration Process between Eastern and Western Europe. Springer, 2001.

Phinnemore, "Enlargement to the East: Romania," Hilary Ingham and Mike Ingham, EU Expansion to the East - Prospects and Problems (Edward Elgar, 2002) 222-245.

Pollack, Mark A. "The Engines of Integration? Supranational Autonomy and Influence in the European Union." Sandholtz, Wayne and Alec Stone Sweet. European Integration and Supranational Governance. Oxford University Press, 1998. 217-250.

-. "The Commission as an Agent." At the Heart of the Union - Studies of the European Commission. Ed. Neill Nugent. Second Edition. Macmillan, 2000. 111-131.

-. The Engines of European Integration - Delegation, Agency, and Agenda Setting in the EU. Oxford University Press, 2003.

Poole, Peter A. The EU's Eastern Enlargement. London: Praeger, 2003.

Schimmelfennig, Frank and Ulrich Sedelmeier. The Europeanisation of Central and Eastern Europe. Ithaca and London: Cornell University Press, 2005.

Schimmelfennig, Frank. "The Community Trap: Liberal norms, rethorical action and the eastern enlargement of the European Union." Schimmelfennig, Frank and Ulrich Sedelmeier. The Politics of European Union Enlargement - Theoretical Approaches. London and New York: Routledge, 2005. 142-172.

-. "The Process of Enlargement - Problems, Interests and Norms." Richardson, Jeremy. European Union - Power and Policy-Making. Third. Routledge, 2006. 207225.

Sedelmeier, Ulrich. Constructing the Path to Eastern Enlargement - The Uneven Policy Impact of EU Identity. Manchester University Press, 2006.

-. "Eastern Enlargement: Risk, Rationality, and Role-Compliance." Cowles, Maria Green and Michael Smith. The State of the European Union - Risks, Reform, Resistance, and Revival. Vol. 5. Oxford: Oxford University Press, 2000. 164-186. 
Steunenberg, Bernard. Widening the European Union - The politics of institutional change and reform. London and New York: Routledge, 2002.

Velichkov, Kamen. "Bulgaria's EU Accession Negotiations: Acheivements and Challanges," Department of Political Science int he University of Sofia, 23 August $2010<\mathrm{http} / / /$ revistas.ucm.es/cee/15766500/articulos/PAPE0404120004A.PDF>.

Yi, Chunyao. "Emergence of Regionalism: About State Preference Formation." POLIS WORKING PAPER No.23 January 2007.

\section{Interviews:}

Babicz, Marcel. Interview at the Permanent Representation of Slovakia Martin Manolov. 5 May 2009.

Broilo, Miroslaw. Interview at the Polish Permanent Representation Martin Manolov. 5 May 2009.

Commission, Interview at the European. The Role of the Commission in the Accession of Bulgaria and Romania Martin Manolov. 15 May 2009.

Orban, Leonard. Interview at the European Commission Martin Manolov. 4 May 2009

Representation, Interviewee from a Member State Permenent. The Role of the Commission in Enlargement Martin Manolov. 8 May 2009.

Serpe, Ion. Interview at the Romanian Permanent Representation Martin Maanolov. 4 May 2009.

Yotova, Ralitza. Interview at the Bulgarian Permanent Representation to the European Union Martin Manolov. 4 May 2009.

\section{Documents:}

Commission. Agenda 2000: For a Stronger and Wider Union. European Commission. Brussels: European Commission, June 1997.

一. Conditions for Enlargement. 15 June 2010. European Commission. 19 August $2010<\mathrm{http} / / / \mathrm{ec}$.europa.eu/enlargement/the-policy/conditions-forenlargement/index_en.htm>.

-. COMMISSION DECISION of 13 December 2006 establishing a mechanism for cooperation and verification of progress in Bulgaria to address specific benchmarks in the areas of judicial reform and the fight against corruption and organised crime. European Commission. Brussels: European Commission, December 13th 2006. 
- COMMISSION DECISION of 13 December 2006 establishing a mechanism for cooperation and verification of progress in Romania to address specific benchmarks in the areas of judicial reform and the fight against corruption (notified under document number C(2006) 6569) (2006/928/EC). European Commission. Brussels: European Commission, December 13th 2006.

- Commission Opinion on Bulgaria's Application for Membership of the European Union. European Commission. Brussels: European Commission, July 1997.

- Commission Opinion on Romania's Application for Membership of the European Union. European Commission. Brussels: European Commission, July 1997.

-. COMMUNICATION FROM THE COMMISSION Comprehensive monitoring report on the state of preparedness for EU membership of Bulgaria and Romania. European Commission. Brussels: European Commission, October 25th 2005.

- COMMUNICATION FROM THE COMMISSION Monitoring report on the state of preparedness for EU membership of Bulgaria and Romania. European Commission. Brussels: European Commission, October 26th 2006.

- COMMUNICATION FROM THE COMMISSION Monitoring report on the state of preparedness for EU membership of Bulgaria and Romania. European Commission. Brussels: European Commission, May 16th 2006.

-. COMMUNICATION FROM THE COMMISSION TO THE COUNCIL AND THE EUROPEAN PARLIAMENT Roadmaps for Bulgaria and Romania. European Commission. Brussels: European Commission, November 13th 2002.

-. COMMUNICATION FROM THE COMMISSION TO THE COUNCIL AND TO THE EUROPEAN PARLIAMENT Strategy Paper of the European Commission on progress in the enlargement process. European Commission. Brussels: European Commission, October 6th 2004.

- COMPOSITE PAPER Reports on progress towards accession by each of the candidate countries. European Commission. Brussels: European Commission, October 1999.

- COMPOSITE PAPER Reports on progress towards accession by each of the candidate countries. European Commission. Brussels: European Commisssion, November 1998.

-. CONTINUING ENLARGEMENT Strategy paper and Report fot the European Commission on the progress towards accession by Bulgaria, Romania and Turkey. European Commission. Brussles: European Commission, November 5th 2003. 
-. Enlargement Strategy Paper Report on progress towards accession by each of the candidate countries. European Commission. Brussels: European Commission, November 8th 2000.

—. "EUROPA." 2001. Enlargement of the European Union - An historic opportunity. European Commission. $\quad 02 \quad$ April 2009 $<$ http://ec.europa.eu/enlargement/archives/pdf/press_corner/publications/corpus_en.p $\mathrm{df}>$.

- Europe and the Challange of Enlargement. European Commission. Brussels: European Commission, June 1992.

-. Follow up to Commission Communication on "The Europe Agreements and Beyond: A Strategy to Prepare the Countries of Central and Eastern Europe for Accession". European Commission. Brussels: European Commission, July 27th 1994.

- Making a success of enlargement Strategy Paper and Report of the European Commission on the progress towards accession by each of the candidate countries. European Commission. Brussels: European Commission, November 13th 2001.

-. PreLex. European Commission. 27 July 2010 $<$ http://ec.europa.eu/prelex/detail_dossier_real.cfm?CL=en\&DosId=103440>.

-. Progress in the negotiations, European Commission, 23 August 2010 $<\mathrm{http} / /$ ec.europa.eu/enlargement/archives/enlargement_process/future_prospects/neg otiations/eu10_bulgaria_romania/chapters/index_en.htm>.

-. "Proposal for a COUNCIL AND COMMISSION DECISION on the conclusion of the Europe Agreement between the European Communities and their Member States, of the one part. and Bulgaria, of the other part." European Commission, 18/02/1993.

-. "Proposal for a COUNCIL AND COMMISSION DECISION on the conclusion of the Europe Agreement between the European Communities and their Member States, of the one part, and Romania, of the other part." European Commission, 21/12/1992.

-. Proposal for a Council Decision on the principles, priorities, intermediate objectives and conditions contained in the Accession Partnership with Bulgaria. European Commission. Brussels: European Commission, February 1998.

- Proposal for a Council Decision on the principles, priorities, intermediate objectives and conditions contained in the Accession Partnership with Romania. European Commission. Brussels: European Commission, February 1998. 
-. The Europe Agreements and Beyond: A Strategy to Prepare the Countries of Central and Eastern Europe for Accession. European Commission. Brussels: European Commission, July 1994.

- White Paper - Preparation of the Associated Countries of Central and Eastern Europe for Integration into the Internal Market of the Union. European Commission. Brussels: European Commission, May 3rd 1995.

Council. 1778TH COUNCIL MEETING - GENERAL AFFAIRS. Press Release. Council of Ministers. Brussels: Council of Ministers, July 18th 1994.

-. 1790E SESSION DU CONSEIL - AFFAIRES GENERALES. Press Release. Council of Ministers. Luxemburg: Council of Ministers, October 4th 1994.

- 1820TH COUNCIL MEETING - GENERAL AFFAIRS. Council of Ministers. Brussles: Council of Ministers, December 19/20 1994.

-. 1825TH COUNCIL MEETING - GENERAL AFFAIRS. Council of Ministers. Brussles: Council of Ministers, January 23rd 1995.

-. 1827TH COUNCIL MEETING - GENERAL AFFAIRS. Press Release. Council of Ministers. Brussels: Council of Ministers, February 6th 1995.

-. 1847TH COUNCIL MEETING - GENERAL AFFAIRS. Council of Ministers. Brussels: Council of Ministers, May 29th 1995.

-. 1851ST COUNCIL MEETING - INTERNAL MARKET. Council of Ministers. Brussels: Council of Ministers, June 6th 1996.

-. 1853TH COUNCIL MEETING - GENERAL AFFAIRS. Council fo Ministers. Brussels: Council of Ministers, June 12th 1995.

- 2024th GENERAL AFFAIRS - COUNCIL CONCLUSIONS. Council of Ministers. Brussels: Council of Ministers, July 1997.

- 2057th GENERAL AFFAIRS - COUNCIL CONCLUSIONS. Council of Ministers. Brussels: Council of Ministers, December 1997.

-. 2148th GENERAL AFFAIRS - COUNCIL CONCLUSIONS. Council of Ministers. Brussels: Council of Ministers, December 1998.

-. 2308th Generl Affairs - Council Conclusions. Council of Ministers. Brussels: Council of Ministers, November 20th 2000.

-. 2316th General Affairs - Council Conclusions. Council of Ministers. Brussels: Council of Ministers, December 4th 2000. 
-. 2342nd General Affairs - Council Conclusions. Council of Ministers. Brussels: Council of Ministers, April 9th 2001.

- 2356th General Affairs - Council Conclusions. European Council. Brussels: European Council, July 11th 2001.

-. 2397th General Affairs - Council Conclusions. Council of Ministers. Brussels: Council of Ministers, December 10th 2001.

- 2463rd General Affairs - Council Conclusions. Council of Ministers. Brussles: Council of Ministers, November 21st 2002.

-. 2540th General Affairs - Council Conclusions. Council of Ministers. Brussels: Council of Ministers, November 17th 2003.

-. 2540th General Affairs - Council Conclusions. Council of Ministers. Brussels: Council of Ministers, November 17th 2003.

-. 2655th General Affairs - Council Conclusions. Council of Ministers. Brussels: Council of Ministers, April 25th 2005.

-. 2700th General Affairs - Council Conclusions. Council of Ministers. Brussels: Council of Ministers, December 15th 2005.

-. 2755th General Affairs - Council Conclusions. Council of Ministers. Brussels: Council of Ministers, October 17th 2006.

- 2770th General Affairs - Council Conclusions. Council of Ministers. Brussles: Council of Ministers, December 11th 2006.

-. "94/907/EC, ECSC, Euratom: Council and Commission Decision of 19 December 1994 on the conclusion of the Europe Agreement between the European Communities and their Member States, of the one part, and Romania, of the other part." 31 December 1994. Eur-Lex. Council. 27 July $2010<$ http:/eurlex.europa.eu/LexUriServ/LexUriServ.do?uri=CELEX:31994D0907:EN:HTML>.

-. "94/908/EC, ECSC, Euratom: Decision of the Council and the Commission of 19 December 1994 on the conclusion of the Europe Agreement between the European Communities and their Member States, of the one part, and the Republic of Bulgaria, of the other part." 19 December 1994. Eur-Lex. Council. 27 July $2010<$ http://eurlex.europa.eu/LexUriServ/LexUriServ.do?uri=CELEX:31994D0908:EN:HTML>.

-, CONSOLIDATED VERSION OF THE TREATY ON THE FUNCTIONING OF THE EUROPEAN UNION, Official Journal of the European Union, Council of Ministers (Brussels: Council of Ministers, 2008) 
-. EUROPEAN UNION CONSOLIDATED VERSIONS OF THE TREATY ON EUROPEAN UNION AND OF THE TREATY ESTABLISHING THE EUROPEAN COMMUNITY. Council of Ministers. Brussels: Official Journal of the European Union, December 29th 2006.

- On assistance to the applicant States in the framework of the pre-accession strategy, and in particular on the establishment of Accession Partnerships. Council of Ministers. Brussels: Council of Ministers, March 1998.

- Presidency report to the European Council on enlargement of the Union and Agenda 2000. Council of Minisers. Brussels: European Parliament, December 1997.

- PROTOCOL Concerning the conditions and arrangements for admission of the republic of Bulgaria and Romania to the European Union. Council of Ministers. Brussels: Council of Ministers, June 21 st 2005.

- TREATY CONCERNING THE ACCESSION OF THE REPUBLIC OF BULGARIA AND ROMANIA TO THE EUROPEAN UNION. Council of Ministers. Brussles: Council of Ministers, June 212005.

Council, European. Presidency Conclusions. Euroepan Council. Helsinki: European Council, December 1999.

-. Presidency Conclusions. European Council. Copenhagen, June 1993.

- Presidency Conclusions. Euroepan Council. Brussels: European Council, June 2004.

- Presidency Conclusions. European Council. Thessaloniki: European Council, June 2003.

- Presidency Conclusions. European Council. Goteborg: European Council, June 2001.

- Presidency Conclusions. European Council. SANTA MARIA DA FEIRA: European Council, June 2000.

- Presidency Conclusions. European Council. Cardiff: European Council, June 1998.

-. Presidency Conclusions. European Council. Amsterdam: European Council, June 1997.

- Presidency Conclusions. European Council. Florence: European Council, June 1996. 
-. Presidency Conclusions. European Council. Cannes: European Council, June 1995.

—. Presidency Conclusions. European Council. Corfu: European Council, June 1994.

- Presidency Conclusions. European Council. Lisbon: European Parliament, June 1992.

- Presidency Conclusions. European Council. Brussels: European Council, December 2006.

- Presidency Conclusions. European Council. Brussels: European Council, December 2004.

- Presidency Conclusions. European Council. Brussels: European Council, December 2003.

- Presidency Conclusions. European Council. Copenhagen: European Council, December 2002.

- Presidency Conclusions. European Council. Brussels: European Council, December 2001.

-. Presidency Conclusions. European Council. Nice: European Council, December 2000 .

-. Presidency Conclusions. European Council. Vienna: Euroepan Council, December 1998.

- Presidency Conclusions. Euroepan Council. Luxemburg: European Council, December 1997.

-. Presidency Conclusions. European Council. Dublin: European Council, December 1996.

-. Presidency Conclusions. European Council. Madrid: European Council, December 1995.

-. Presidency Conclusions. Euroepan Council. Essen: European Council, December 1994.

- Presidency Conclusions. European Council. Edinburgh: European Parliament, December 1992. 
-. Presidency Conclusions (part 2) concerning relations with the Soviet Union and the countries of Central and Eastern Europe. European Council. Rome, December 1990. 